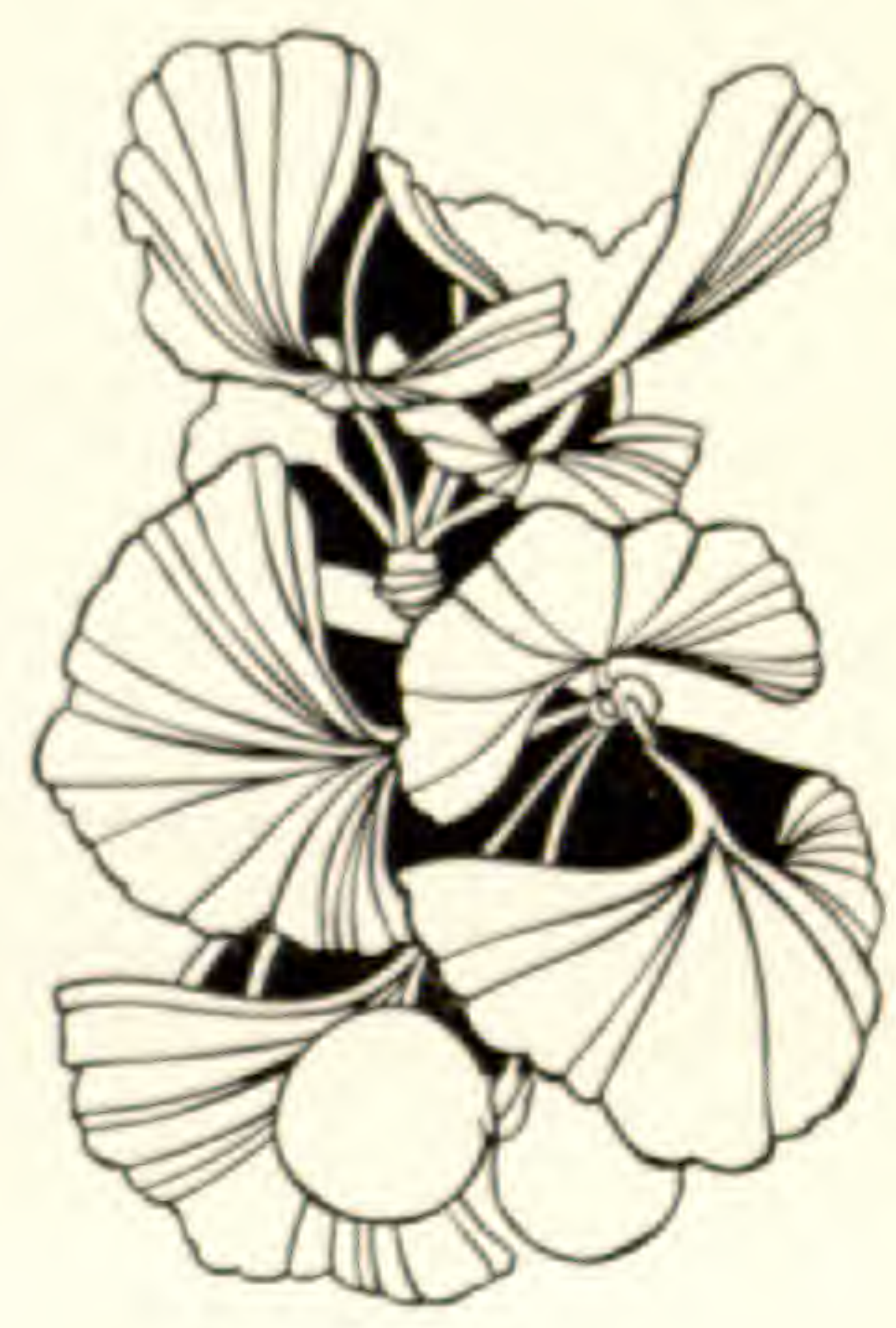

Reprinted from

Journal of the Arnold Arboretum Vol. 55, Number 1

January, 1974 


\section{BIGELOW'S "AMERICAN MEDICAL BOTANY"}

\section{GüNTHER BuchHEIM}

American medical botany by Jacob Bigelow (1787-1879) is a threevolume work in which 60 species of American medicinal plants are described and illustrated. Its publication dates are usually given as "18171820." These are the inclusive title-page dates of the volumes: vol. 1 is dated 1817, vol. 2: 1818, vol. 3: 1820. However, this work was originally published in six parts, and not in volumes: two parts forming each volume. With the exception of volume 1 part 1 , the other five parts are provided with part titles, each being an integral part of the first gathering of each part. These part titles are in the form of a half title and are undated, thus they are of no value in elucidating the dates of publication. The copy of this work in the Duke University, Medical Center Library, Trent Collection, at Durham, North Carolina (NcD-MC) was loaned to the Hunt Botanical Library for this study through the kindness of Dr. G. S. T. Cavanagh, librarian. This copy is distinctive in that the six parts are preserved in their original green boards, and with the paper untrimmed; features that proved to be of high bibliographical importance, especially for determination of dates, collation, and paper size.

The outside front covers give the title as

AMERICAN | MEDICAL BOTANY | WITH | COLOURED ENGRAVINGS. BY JACOB BIGELOW, M.D. | Member of the American Academy of Arts and Sciences; of the American Philosophical | Society, \&c. Rumford Professor and Lecturer on Materia Medica and Botany in Harvard University.

After the volume and part number, there follows enumeration of the plants described in each part (10 species), together with the plate numbers. The place of publication, and name of publisher and printer, is the same as on the title-pages. Significantly, the dates imprinted on each cover differ from those on the title-pages. Although Graesse, Trésor de livres rares et précieux 1: 424. 1950 [reprint], Jackson, Guide to the literature of botany p. 360. 1881, and Savage (Comp.), Catalogue of the printed books and pamphlets in the library of the Linnean Society of London ed. 2, p. 67. 1925, list the correct inclusive dates (1817-1821), no reference is known which gives the correct publication dates of all the parts.

The dates recorded on the front boards are: Vol. I. Part I: 1817; Vol. I. Part II: 1818; Vol. II. Part I: 1819; Vol. II. Part II: 1819; Vol. III. Part I: 1820; Vol. III. Part II: 1821. In conclusion, volume 1 was published in 1817-1818 (title-page dated 1817), volume 2 in 1819 (titlepage dated 1818), and volume 3 in 1820-21 (title-page dated 1820).

Additionally, a printed text is on the outside back covers of the parts belonging to volumes 1 and 2 . That on volume 1 , part 1 is an announce- 
ment by the publisher that part 2 of the same volume will shortly be published, followed by an advertisement of books, none of them botanical. Volume 1, part 2 represents a prospectus of the present work. It is dated May 1818 and states that "Two half volumes are already published." Volume 2, part 1 bears advertisements of books either published by Cummings and Hilliard, or which are in the press. The first item mentioned is AMERICAN MEDICAL BOTANY, Nos. 1, 2, \& 3. That for Volume 2, part 2, reports an error on the front cover of Volume 2 , part 1 , where the plate numbers are reported as "I, II" etc. instead of "XXI, XXII" etc. It reports further that a work titled Outlines of Botany . . . by John Locke is in press [this work was published in 1819] and lists additional nonbotanical titles.

Using these data, and considering the contents and bibliographical characteristics of both the NcD-MC and HBL copies, the following formal treatment has been prepared:

American medical botany. 3 vols. Boston, 1817-1820 [1817-1821].

AMERICAN | MEDICAL BOTANY, | BEING-A COLLECTION | OF THE NATIVE MEDICINAL PLANTS | OF THE | UNITED STATES, | CONTAINING THEIR | BOTANICAL HISTORY AND CHEMICAL ANALYSIS, | AND PROPERTIES AND USES | IN | MEDICINE, DIET AND THE ARTS, | WITH | COLOURED ENGRAVINGS. | [very short thick-thin double rule] | BY JACOB BIGELOW, M.D. | RUMFORD PROFESSOR AND LECTURER ON MATERIA MEDICA AND BOTANY| IN HARVARD UNIVERSITY. | [very short thin-thick double rule ] | VOL. I. | [5 dots in line] | BOSTON: | PUBLISHED BY CUMMINGS AND HILLIARD, AT THE | BOSTON BOOKSTORE, NO. 1, CORNHILL. $|* * * *|$ UNIVERSITY PRESS . . . HILLIARD AND METCALF. | 1817.

[Vol. II] : . . | VOL. II. | . . | BOSTON BOOKSTORE, NO. 1 CORNHILL | . . 1818 .

[Vol. III] : ... $\mid$ MEDICINE, DIET, AND THE ARTS, | WITH COLOURED ENGRAVINGS, | [short double rule] | BY JACOB BIGELOW, M.D. RUMFORD PROFESSOR, AND PROFESSOR OF MATERIA MEDICA IN HARVARD UNIVERSITY. | [short double rule] | VOL. III. | [short thick-thin double rule] | BOSTON: | PUBLISHED BY CUMMINGS AND HILLIARD, AT THE BOSTON | BOOKSTORE, NO. 1 CORNHILL. | [very short double rule] | UNIV. PRESS . . . HILLIARD AND METCALF. 1820.

Collation: $8^{\circ}$ in 4's: Vol. 1 : $1^{4} 2^{2} 3-14^{4}\left(-14_{4}\right) \quad 15^{4} 16-25^{4} ; i-v$ vi-xi xii 17 18-32 33 34-38 $39 \quad 40-51 \quad 52 \quad 53-5960 \quad 61-65 \quad 66 \quad 67-74 \quad 75 \quad 76-83 \quad 84 \quad 85-8990 \quad 91-95 \quad 96 \quad 97-110$ 111-113 $114-124 \quad 125 \quad 126-132 \quad 133 \quad 134-141 \quad 142 \quad 143-148 \quad 149 \quad 150-154 \quad 155 \quad 156-160161$ 162-168 $169 \begin{array}{lllllllll}170-176 & 177 & 178-186 & 187 & 188-191 & 192 & 193-197 & 198 .\end{array}$

Vol. 2: $1^{4} 2-13^{4} 14^{4} 15-25^{4} ; i-v$ vi-vii viii-ix x-xiii xiv (in NcD-MC copy as "xvi") $\begin{array}{llllllllllllllllllllllll}15 & 16-26 & 27 & 28-33 & 34 & 35-40 & 41 & 42-50 & 51 & 52-58 & 59 & 60-66 & 67 & 68-72 & 73 & 74-81 & 82 & 83-96\end{array}$

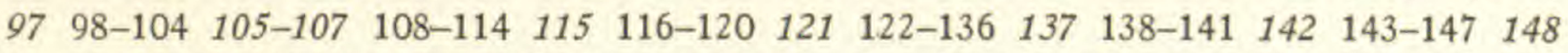
149-153 $154 \quad 155-159160161-165166 \quad 167-170171 \quad 172-187 \quad 188 \quad 189-199200$.

Vol, 3: $1^{4} \quad 2-12^{4} 13^{2}\left(-13_{2}\right) \quad 14^{4} \quad 15-25^{4} \quad 26^{2} ; i-v$ vi-x $11 \quad 12-18 \quad 19 \quad 20-31 \quad 32 \quad 33-42 \quad 43$ 
$\begin{array}{lllllllllllllllll}44-48 & 49 & 50-54 & 55 & 56-60 & 61 & 62-75 & 76 & 77-81 & 82 & 83-91 & 92 & 93-98 & 99-101 & 102-106 & 107\end{array}$

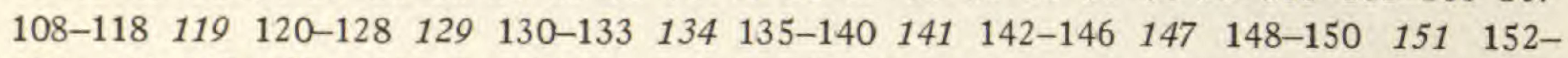
$\begin{array}{llllllllllll}155 & 156 & 157-162 & 163 & 164-173 & 174-175 & 176-177 & 178-179 & 180-187 & 188-189 & 190 & 191\end{array}$ 192-193 194-195 196-197 198.

Contents: Vol. 1: $1_{1} \mathrm{r}$ title, $1_{1} \mathrm{v}$ registration certification for vol. 1 , dated 18 October 1817. $1_{2} \mathrm{r}$ dedication to Reverend John Thornton Kirkland (1770-1840), president of Harvard University, Cambridge, Mass., dated "Boston, October, $1817, " 1_{2} \mathrm{~V} \square . \quad 1_{3}-2_{2} \mathrm{r}$ preface. $2_{2} \mathrm{~V} \square .3_{1}-14_{3}$ text: description of species and their medical uses, including botanical and medical references and explanation of the figures depicted on each plate. $15_{1} \mathrm{r}$ part title for vol. 1 part 2, $15_{1} \mathrm{v} \square$. $15_{2}-25_{1} \mathrm{r}$ continuation of the text. $25_{1} \mathrm{v}-25_{4} \mathrm{r}$ notes. $25_{4} \mathrm{~V}$ contents of vol. 1 .

Vol. 2: $1_{1} \mathrm{r}$ part title for vol. 2 part 1. $1_{1} \mathrm{~V} \square . \quad 1_{2} \mathrm{r}$ title, $1_{2} \mathrm{~V}$ registration certification for vol. 2, dated 28 October 1818. $1_{3}-1_{4} \mathrm{r}$ advertisement by the author. $1_{4} \mathrm{~V} \square . \quad 2_{1}-2_{3}$ preface. $2_{4}-13_{4}$ text. $14_{1} \mathrm{r}$ part title for vol. 2 part 2 , $14_{1} \mathrm{~V} \square$. $14_{2}-24_{2} \mathrm{r}$ continuation of the text. $24_{2} \mathrm{~V}-25_{4} \mathrm{r}$ notes. $25_{4} \mathrm{~V}$ contents of vol. 2 .

Vol. 3: $1_{1} \mathrm{r}$ part title for vol. 3 part $1,1_{1} \mathrm{~V} \square .1_{2} \mathrm{r}$ title, $1_{2} \mathrm{~V} \square .1_{3}-2_{1}$ preface. $2{ }_{2}-13_{1}$ text. $14_{1} \mathrm{r}$ part title for vol. 3 part 2. $14_{1} \mathrm{v} \square .14_{2}-23_{2} \mathrm{r}$ continuation of the text. $23_{2} \mathrm{~V} \square . \quad 23_{3}-23_{4} \mathrm{r}$ notes. $23_{4} \mathrm{~V} \square . \quad 24_{1}-25_{1} \mathrm{r}$ appendix. $25_{1} \mathrm{~V} \square . \quad 25_{2} \mathrm{rV}$ systematic index. $25_{3}-25_{4} \mathrm{r}$ index of Latin names. $25_{4} \mathrm{~V} \square .26_{1}-26_{2} \mathrm{r}$ index of English names. $26_{2} \mathrm{~V}$ contents of vol. 3 .

Running titles vary with the plants described, the Latin binomial being used on the versos, the English name on the rectos. Language used: English.

Plates: 60 colored (colorprinted and handcolored) or partly colored, mixed intaglio plates (engraving, aquatint, stipple engraving) of medicinal plants, numbered I-LX (XIX as "XI"), titled binomially at foot; $207 \times 136 \mathrm{~mm}$. (pl. 2); plates facing descriptions; indexed by Stapf, Index londinensis (pl. 14, Spigelia marilandica, erroneously stated to be in black and white).

\section{ILLUSTRATORS :}

Artist: the author, Jacob Bigelow. All plates unsigned. However, in the work itself (Vol. 1, p. xi; Vol. 2, p. vi) it is clearly stated that the figures have been prepared from original drawings made by the author himself, "with the exception of two or three presented by his friends" (Vol. 2: p. vi).

Engravers: Annin, W. B. (dates unknown): 2 plates, and additionally 23 (or 21) plates in collaboration with Smith; Smith, — (dates unknown): 23 (or 21) plates, all in collaboration with W. B. Annin. 35 (or 37) plates without indication of engraver (pls. 2-6, 8-28, 30, 41, 43-49; also pls. 31 and 58 in NcDMC copy).

PAPER: Halfsheets; size of halfsheet $358 \times 530 \mathrm{~mm}$. [NcD-MC, untrimmed]; white, wove. Plates: white, wove.

PRINTER: The firm of Hilliard and Metcalf, owner of University Press, Cambridge, Mass.

Publisher: Cummings and Hilliard, Boston booksellers.

Dates of Publication: The work was published in 6 parts. Vol. 1, part 1, pp. 
i-xii, 17-110, pls. I-X: 1817 (November or late in October). Vol. 1, part 2, pp. 111-198, pls. XI-XX: 1818 (May). Vol. 2, part 1, pp. i-xiv, 15-104, pls. XXI-XXX: 1819 (early in the year, no later than March). Vol. 2, part 2, pp. 105-200, pls. XXXI-XL. 1819 (before December). Vol. 3, part 1, pp. i-x, 11-98 pls. XLI-L: 1820. Vol. 3, part 2, pp. 99-198, pls. LI-LX. 1821 (January).

Supporting evidence: A) Prepublication announcements in Portico (Baltimore) 4(1/2): 131. 1817 [July/Aug.] ("in press") and in N.Amer. Rev. Misc. J. 5(15): 434. 1817 [Sept.] ("about to be published"). B) Registration certification on the verso of the title-pages of vols. 1 and 2 (18 Oct. 1817; 28 Oct. 1818). C) Prospectus dated May 1818 on outside back cover of vol. 1, part 2; year date 1819 on front cover of vol. 2, part 1 (NcD-MC copy). D) Publication announcements in N. Amer. Rev. Misc. J. 6(16): 145-146. 1818 [Nov. 1817] (Vol. 1, part 1 "just issued"); Amer. Monthly Mag. Crit. Rev. 4(50): 388. 1818 [Mar. 1819] (Vol. 2, part 1); Med.-Chir. Zeitung 1819. IV(97): 293-295. 1819 [6 Dec.] (Vol. 2, part 2); N. Amer. Rev. Misc. J. 12(30): 230-231. 1821 [Jan.] (Vol. 3, part 2). No announcement for vol. 3, part 1 and publishad in 1820 has been yet found by the present author; the earliest seen for this part is in N. Amer. Rev. Misc. J. 12(30): 230-231, 1821 [Jan.].

Reviews: Analectic Mag. 11(1): 1-9. 1818 [Jan.]. - New England J. Med. Surg. 7(1): 61-70. 1818 [Jan.]; 10(2): 157-166. 1821 [Apr.]. - N. Amer. Rev. Misc. J. 6(18): 344-368. 1818 [Mar.]; 9(24): 23-26. 1819 [June], - Ecl. Repert. 8(4): 48i-497. 1818 [Oct.]. - Med.-Chir. Zeitung 1818.IV(89): 161163. 1818 [5 Nov.]; 1819.III(60): 140-143. 1819 [29 July]; 1819.IV(97): 293-295. 1819 [6 Dec.]. - Gött. Gel. Anz. 1819.III(144/145): 1433-1444. 1819 [9 Sept.]; 1820.II(111): 1111-1112. 1820 [10 July]; 1823.II(113): 11211126. 1823 [17 July]. - Neue Entdeck. Pflanzenk. 1: 386-393. 1820. - N Amer. Rev. 13(32): 100-134. 1821 [July]. - London Med. Phys. J. 47(277): 242-244. 1822 [Mar.] - Allg. Lit.-Zeitung (Halle \& Leipzig) 1822.IV(36): 281-284. 1822 [Mar.].-Bull. Sci. Nat. Géol. 3([9]): 59. 1824 [Sept.].Bull. Sci. Méd. (Paris) 3([9]): 69-75. 1824 [Sept.]. - Boston Med. Surg. J. 20(26): 412. 1839 [7 Aug.].

VARIANTS: Two states of leaf $2_{3}$ of volume 2 are known, differing only in the pagination of the verso: xvi [misprint for xiv] and xiv [correct pagination]. The original incorrect pagination occurs in the $\mathrm{NcD}-\mathrm{MC}$ copy, the corrected version e.g. in the HBL copy.

Copies Studied: HBL, NcD-MC; other copies known: AzU, BM, BMNH, CaBVaU, CSfA, CSmH, CSt, CtHT, DLC, DLNM, E-UL, FU, G, GOETUB, GRO-UB, IaAS, IaDaM, ICF, ICJ, IEN-M, In, InNd, K, KyLxT, KyU, LE (vol. 2, part 1 only), Linn., LNT-M, MB, MBAt, MBC, MBHo, MBM, MdBM, MdBP, MeBat, MH-A (Harv. Herb. Libr.), MH-M, MiEM, MiU, MnS, MSaP, MWA, MWCH, MWiW, NB, NBLiHi, NBMS, NcAS, NcD, NcU, Nh, NhM, NjP, NN, NNA, NNNAM, NNS, NRU, NYBG, OC, OClGC, OKU, OO, OrU, PPA, PPAP, PPC, PPF, PPH, PPHor, PPL-R, PU, RPB, RPM, ScCMu, ScU, TNV, ViRMC, ViU, ViW, VtU, W (vol. 1 only), WIS-R. - US library holdings according to NUC (The National Union Catalog. Pre-1956 imprints) 57: 283. 1969, and Shaw and Shoemaker (American Bibliography) 1817: 44. 1963. 
Notes: The continuous sequence of roman and arabic page numbers is worth being mentioned. The gap in pagination in volume 1 (pp. xiii-xvi are lacking) proves that the preliminaries were printed later than the text proper and that the original estimate of 16 preliminary pages was not realistic.

Leaves $14_{4}$ of vol. 1 and $13_{2}$ of volume 3 , both blank, are present in the NcD$\mathrm{MC}$ copy. The pagination, however, indicates that these blank leaves were intended to be cut out, as was done in the HBL copy.

The wrong folding of gathering 1 of volume 2 in the $\mathrm{NcD}-\mathrm{MC}$ copy results in the following irregular arrangement: $1_{2} 1_{1} 1_{4} 1_{3} ; i i i-i v i-i i$ vii viii $v$ vi.

In volumes 2 and 3 of the HBL copy the part titles for part 1 are inserted at the wrong places:

Vol. 2: $1_{2}-1_{4} \quad 2_{1}-2_{3} \quad 1_{1} 2_{4}$; $i i i-v$ vi-vii viii-ix $\mathrm{x}$-xiv $i-i i \quad 1516$.

Vol. 3: $1_{2}-1_{4} \quad 2_{1} 1_{1} 2_{2}-2_{4} ; i i i-v$ vi-x $i-i i \quad 11 \quad 12-i 6$.

This work is considered Bigelow's most important contribution to medical botany. It is outstanding for the mixed intaglio processes used for the preparation of the copper plates, being a combination of engraving and aquatint and sometimes stipple engraving. Of the 60 species figured, four are illustrated here for the first time (Gentiana catesbaei Walt., Solidago odora Ait., Statice caroliniana Walt. [= Limonium carolinianum (Walt.) Britton] and Polygala rubella Willd. $[=P$. polygama Walt. $])$.

Hunt Institute For Botanical Documentation

Carnegie-Mellon University

Pittsburgh, Pennsylvania 15213 


\section{AMERICAN \\ MEDICAL BOTANY, \\ BEING A COLLECTION \\ OF THE \\ NATIVE MEDICINAL PLANTS

OF THE

\section{UNITED S'TATES,}

Containing their

BOTANICAL HISTORY AND CHEMICAL ANALYSIS, AND PROPERTIES AND USES

IN

MEDICINE, DIET AND THE ARTS,

WITH

COLOURED ENGRAVINGS.

\section{BY JACOB BIGELOW, M. D.}

RUMFORD PROFESSOR AND LECTURER OX MATERIA MEDICA AND BOTANY IN HARVARD UNIVERSITX.

VOL. I.

Q

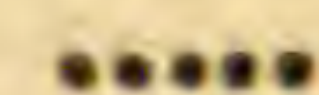

BOSTON :

PUBLISHED BY CUMMINGS AND HILLIAD, AT THF: BOSTON BOOKSTORE, No. 1, CORNHILL.

***\%

UNIVERSITY PRESS...HILLIARD AXN METCALE.

1817.

Mo. Bot. Garden,

1893 


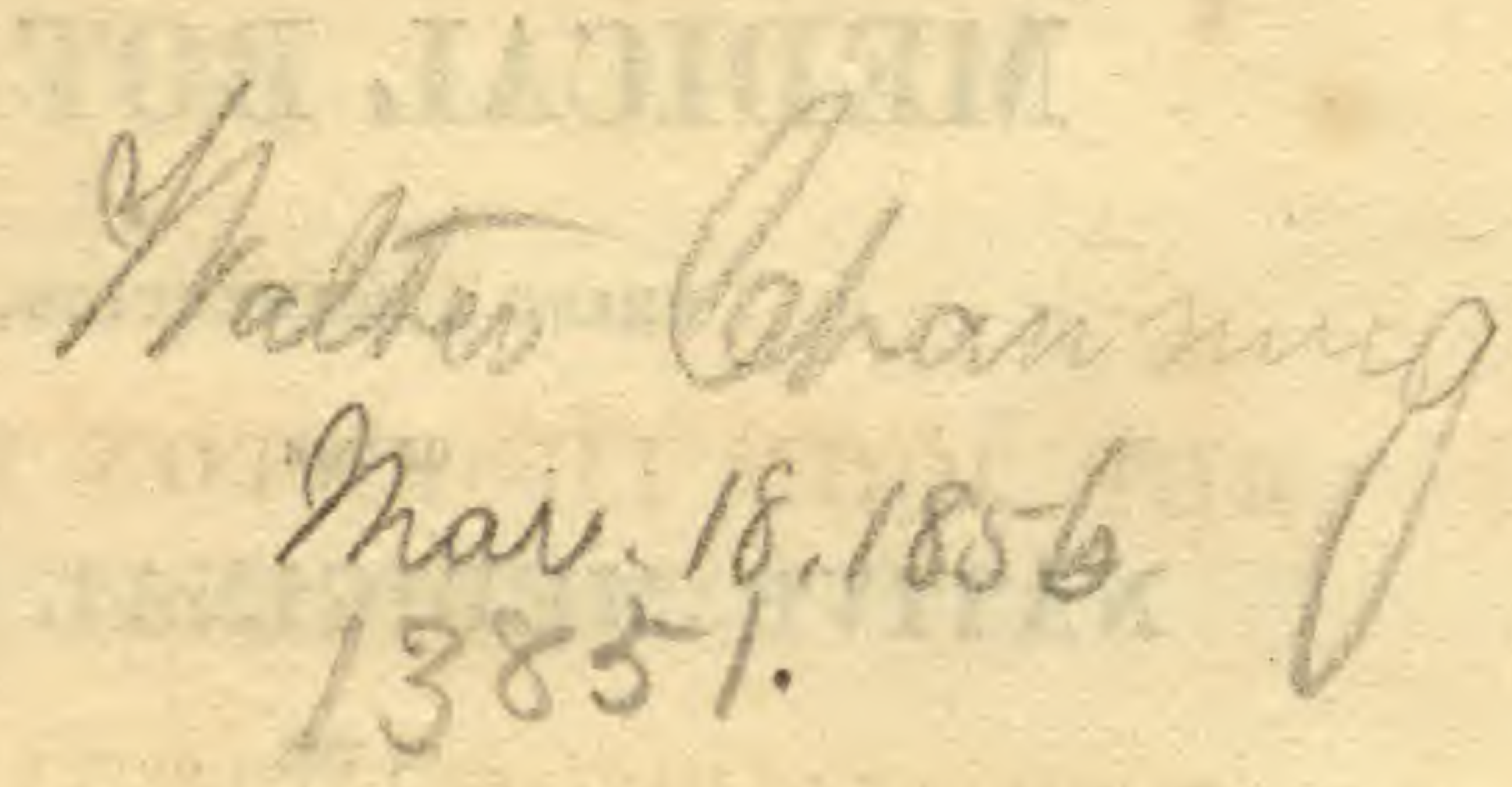

\section{District of Massachusetts, to wit :}

District Clerk's office.

BE it remembered, that on the eighteenth day of October, A. D. 1817, and in the forty second year of the independence of the United States of America, Jacob Bigelow, M. D. of the said district, has deposited in this office the title of a book, the right whereof he claims as author, in the words following, viz.

"Anerican Medical Botany, being a collection of the native medicinal plants of the United States, containing their botanical history and chemical analysis, and properties and uses in medicine, diet and the arts, with coloured engravings. By $J_{A \in O B}$ Gigelow, M. D. Rumford Professor and Lecturer on Materia Medica and Botany in Harvard University. Vol. I."

In conformity to the act of the congress of the United States, entitled "An act for the encouragement of learning, by securing the copies of maps, charts, and books, to the authors and proprietors of such copies during the times therein mentioned;" and also to an act, entitled, "An act supplementary to an act, entitled, An act for the encouragement of learning, by securing the copies of maps, sharts, and books, to the authors and proprietors of such copies, during the times therein mentioned, and extending the benefits thereof to the arts of designing, engraving, and etching historical and other prints."

JNO. W. DAVIS, Clerk of the district of Massachusetts. 
TO THE

\section{REV. JOHN THORNTON KIRKLAND, \\ D. D. L L. D.}

PRESIDENT OF HARVARD UNIVERSITY IN CAMBRIDGE,

MASSACHUSETTS.

DEAR SIR,

THE present flourishing state of the Institution, over which you preside, cannot be ascribed to any more efficient cause, than to the zeal and ability, with which y ou have watched over its interests.

Those, who in any measure derive from this Institution their opportunities of being useful, may with justice direct

- their first acknowledgments to you.

Being confident, that no attempt for the promotion of useful knowledge will be regarded by you with indifference, I am happy in offering to you, in the present volume, a testimony of my respect and esteem.

J. B.

Boston, October, 1817. 


\section{PRLFACE.}

Having long meditated the commencement of a work on the medicinal vegetables of the United States, and feeling myself obligated for its completion, by the instructions from the University in which $I$ have the honor to hold a professorship; it may be proper to make at the outset some general statements of the motives and objects of such a publication.

The Materia Medica, comprising the great body of medicinal agents now in use in the hands of physicians, cannot be said to need an increase in the number of its articles. It is already incumbered with many superfluous drugs; even its active substances are more numerous than can be of use to any one physician, so that it seems quite as susceptible of benefit from reduction as from augmentation in the number of its materials. Under these circumstances, the introduction of new medicines can only be authorized, where 
from the peculiarity of their powers, or the facility of their acquisition, they are calculated to take the place of others previously in use.

of our present stock of medicinal agents, collected from various parts of the globe, a few appear to be anique in their powers, and could not in the present state of our knowledge, be superseded by other substances. A number more possess active properties, yet of a kind, for which substitutes might be found among the native productions of almost every country into which they are imported. There are others which possess little activity or value, but which, from a sort of fashion, are still articles of commerce and consumption.

In the management of diseases, the physician requires instruments of determinate power, on the operation of which, he may build definite expectations. Many such are already in his hands. Yet when we consider how small a portion of the vegetable kingdom has been medically examined, there can be little doubt that a vast number of active substances, many perhaps of specific efficacy, remain for future inquirers to discover. In this respect, every successive age is making acquisitions. But a century or two ago, the civilized worlu were unacquainted with the properties of ipecacuanha, of jalap, and the Peruvian 
bark. The powers of digitalis in certain diseases are of very recent observation. At the present day, we are speculating on the probable composition of a vegetable medicine, which cures the gout.

Medicinal substances frequently owe their first introduction to accident. Many have been at first brought up as antidotes for the poison of serpents, as remedies for syphilis, or as specifics against imaginary diseases. Previously to this, they were neglected as useless, or avoided as dangerous. It is a subject of some curiosity to consider, if the knowledge of the present Materia Medica were by any means to be lost, how many of the same articles would again rise into notice and use. Doubtless a variety of new substances would develop unexpected powers, while perhaps the poppy would be shunned as a deleterious plant, and the cinchona might grow unmolested upon the mountains of Quito.

It is the policy of every country to convert as far as possible its own productions to use, as a mean of multiplying its resources, and diminishing its tribute to foreigners. The plants of the United States are various in their character in proprotion to the extent of latitudes and climates, which our country embraces. Among those which 
have been medicinally investigated, are many of useful properties and decided efficacy. Several departments of the Materia Medica may be amply supplied from our own forests and meadows, although there are others, for which we must as yet depend on foreign countries. We have yet to discover our anodynes and our emetics, although we abound in bitters, astringents, aromatics and demulcents. In the present state of our knowledge we could not well dispense with opium and ipicacuanha, yet a great number of foreign drugs, such as gentian, columbo, chamomile, kino, catechu, cascarilla, canella, \&c. for which we pay a large annual tax to other countries, might in all probability be superceded by the indigenous products of our own. It is certainly better that our own country people should have the benefit of collecting such articles, than that we should pay for them to the Moors of Africa, or the Indians of Brazil.

Independent of the frauls of adulteration, which may be practised by savages upon drugs, whose origin is hardly known to Europeans, the embarrassments occasioned by the chances of war and commercial restrictions, form serious objections to an exclusive dependence on foreign medicines. It is but a few years since some circum- 
stances of this sort occasioned a sudden and enormous rise in the price of opium, and a general inquiry, what could be substituted for opium when the usual supplies should have failed.

In a work like the present, although we cannot hope to supply all the desiderata of an indigenous Materia Medica; yet it will be satisfactory to have done something towards an investigation of the real properties of our most interesting plants, and to have facilitated a knowledge of them in those, to whom they may be useful. In a pursuit of this kind, the botanist has views even beyond the physician. To him it is important not only to know what plants have properties, that are eminently useful, but also to know, what are the properties and uses of all the plants which surround him. In proportion as inquiries of this sort are pursued, the natural resources of a country become developed, and its natural disadvantages compensated. We are told that in China every plant is applied to some valuable purpose, and there is scarcely a weed that has not its determinate use.* A learned author ${ }^{*}$ observes, that "no writer whatever has rendered the natural productions of the happiest and most luxuriant climate of the globe, half so interesting or instruc-

* Macartney's Embassy, vol, ii. chap. II. † Sir J. E. Smith. 
tive, as Linnæus has made those of his own northern country."

Under the title of American Medical Bota$\mathrm{NY}$, it is my intention to offer to the public a series of coloured engravings of those native plants, which possess properties deserving the attention of medical practitioners. The plan will likewise include vegetables of particular utility in diet and the arts; also poisonous plants which must be known, that they may be avoided. In making the selection, I have endeavoured to be guided by positive evidence of important qualities, and not by the insufficient testimony of popular report. In treating of each plant, its botanical history will be given; the result of such chemical examinations as I have been able to make of its constituent parts, and lastly its medical history. The botanical account will be found more diffuse than is necessary for exclusive botanists. The chemical inquiries are made chiefly with a view to the pharmaceutical preparations of each plant, or to interesting principles it may contain. Its medical history will contain such facts, relative to its operation on the human system, as are known to me from my own observation, or the evidence of those, who are qualified to form correct opinions on the subject. 
I am by no means ambitious to excite an interest in the subjects of this work, by exaggerated accounts of virtues which do not belong to them. Much harm has been in medicine, by the partial representations of those, who, having a point to prove, have suppressed their unsuccessful experiments, and brought into view none but favorable facts. If, from a desire of avoiding error, I have not always been able to establish fully the character of a native vegetable, it will be recollected that many foreign drugs, which have been for centuries in use, have still an unsettled reputation as to their powers and modes of operating.

The figures of the present volume have been engraved and coloured from original drawings, made principally by myself. Dissections of the flower and fruit have been added to each for the use of botanical students. The subsequent portions of the work will be issued as rapidly as is consistent with their faithful execution.

At the end will be added an appendix or supplement, containing such facts relative to the plants already published, as may have come to light since their publication. 


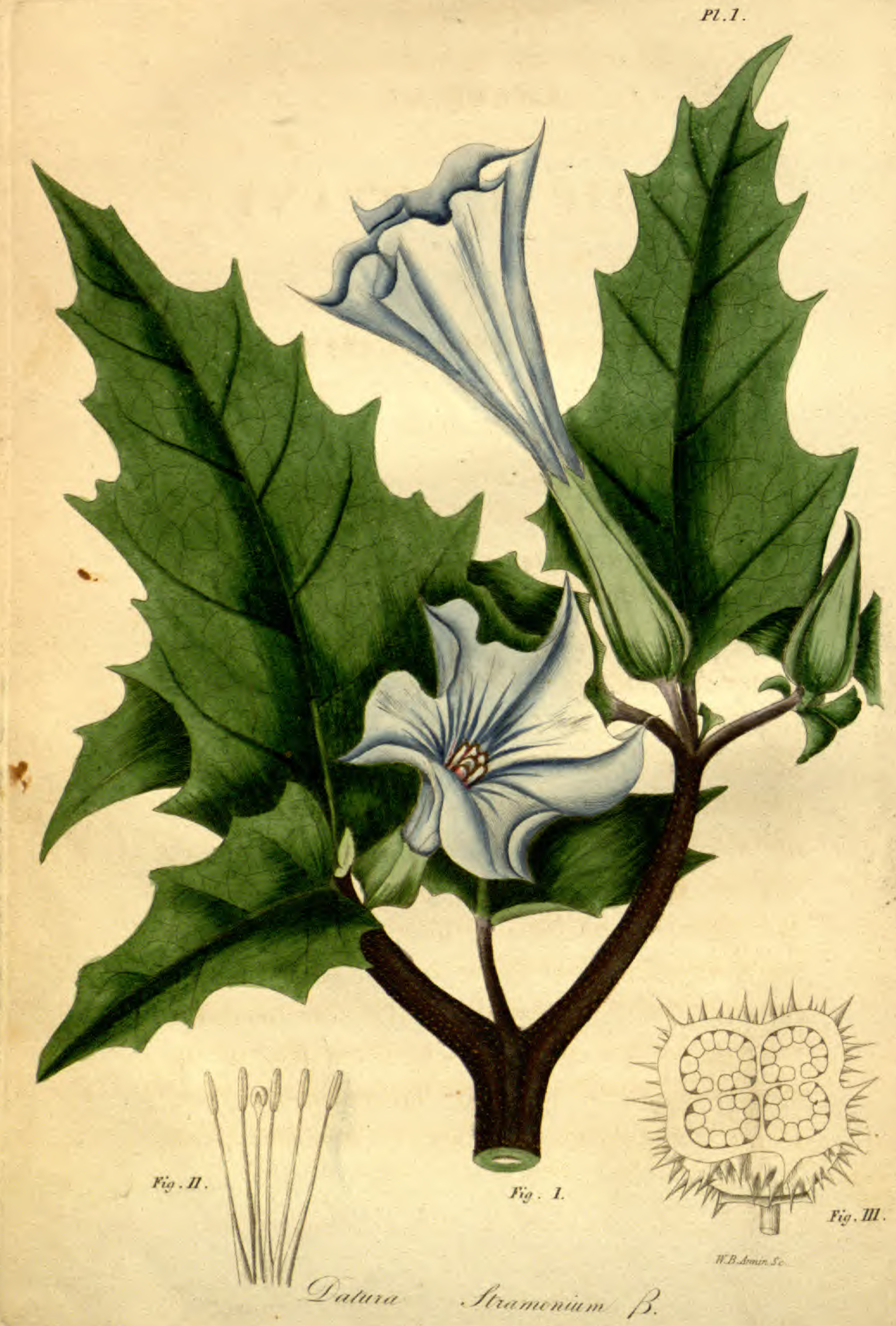




\title{
AMERICAN
}

\section{MEDICAL BOTANY.}

\section{DATURA STRAMONIUM.}

\author{
Thorn Apple. \\ $=$
}

PLATE I.

The Datura Stramonium is a wandering annual plant, which follows the progress of cultivation, and is rarely found remote from the vicinity of dwellings. It occurs in every part of the Atlantic coast from Maine to the Floridas, and is also found in the Western States in the neighbourhood of settlements. Its favorite haunts are the borders of fields and roadsides, among rubbish and in neglected spots of rich ground. It emigrates with great facility, and often springs up in the ballast of ships, and in earth carried from one country to another. This circumstance in Europe has undeservedly given rise to the opinion, that it is originally an American plant. Its native country, however, is doubtful, from 
the want of authentic descriptions of sufficient antiquity. One of the oldest satisfactory accounts of it is that of Gerarde in 159\%, who has published a description and figure of this plant, and states that it was introduced into England by himself, from seeds received from Constantinople. [Note A.]

Its common name in Europe, derived from the form of its fruit, is Thorn apple. In this country its provincial names are Apple of Peru, Devil's apple, and Jamestoren weed. It is a plant of rank growth and luxuriant foliage, varying in height from one to six feet, according to the soil in which it grows. In Carolina it begins to flower in May, and in Massachusetts about the latter part of July, and continues until the arrival of frosts.

The Datura Stramonium belongs to the first order of the fifth class in the Linnæan artificial arrangement. In its natural order it is found among the Luridre of Linnzus and the Solaner of Jussieu. The following are the essential marks which characterize the genus Datura. The corolla funnel form and plaited. The calyx tubular, angular and deciduous. The capsule four valved.-Under this genus are comprehended a number of species, a great part of which are natives of warm latitudes. The species Stramonium is distinguished from the rest by the follow. 
ing character. Capsules thorny, erect, ovate; leaves ovate, angular, smooth.-A more particular description of the plant is as follows. Stem erect, simple at bottom, much branched at top by repeated forks, smooth or slightly pubescent, hollow in the large plants, often solid in small ones. Leaves given off from the forks of the stem, five or six inches long, acute, irregularly sinnated and toothed, with large acute teeth and round sinuses, the sides of the base extending unequally down the petiole. Flowers single, axillary, on short stalks, erect or nodding. Calyx composed of one leaf, tubular, with five angles and five teeth, deciduous by breaking off from its base. Corolla funnel shaped with a long tube, five angled, its margin waved and folded, and terminating in five acuminate teeth. Stamens growing to the tube by their fllaments, with oblong erect anthers. Germ superior, hairy with the rudiments of spines, ovate; style as long as the stamens; stigma obtuse, parted at base. Capsule ovate, fleshy, covered with thorns, four valved, four celled, opening at top. Seeds numerous, reniform, black, attached. to a longitudinal receptacle, which occupies the centre of each cell.

At least two distinct varieties of Datura Stramonium are common in the United States. One 
of these has a green stalk and white flowers, and agrees with the figures of Sowerby and Woodville, except that the anthers are somewhat longer and the dissepiment of the capsule thinner. The second variety, the one represented in our figure, has a dark reddish stem, minutely dotted with green ; and purple flowers striped with deep purple inside. It is generally a larger plant, and its stem more universally hollow. This variety is probably the D. tatula of Linnæus, answering to the description in the Species plantarum. The distinguishing marks laid down between the two plants are not sufficient to make them distinct species. I have cultivated both together and watched them throughout their growth, without being able to detect any difference except in colour. Their sensible and medical properties are the same. Sir James Kidward Smith has lately informed me, that on consulting the herbarium of Linnæus, the original specimens of $\mathbf{D}$. Stramonium and tatula did not appear to be more than varieties of the same plant. [Note B.]

Every part of the Stramonium, when recent, has a strong, heavy, disagreeable odour, and a bitter, nauseous taste. Taken internally it proves a violent narcotic poison, affecting the mind and body in the most powerful manner. Its usual 
consequences when swallowed in considerable quantity, are vertigo and confusion of mind, insensibility of the retina, occasioning dilatation of the pupil and loss of sight, tremors of the limbs and loss of the power of voluntary motion, headach, dryness of the throat, nausea and vomiting, anxiety and faintness, and sometimes furious delirium. If the amount taken be large and not speedily ejected from the stomach, the symptoms pass into convulsions or lethargic stupor, which continue till death. When not fatal, its effects, like those of other narcotics, are temporary, disappearing in from one to two days, and frequently in a shorter period. - The remedies to be resorted to in cases of poison from Stramonium, are a prompt emetic, followed by a free use of vegetable acids and strong coffee.

Many stories have been related of the power of this and other species of Datura to produce mental alienation, without at the same time materially affecting the body. [Note C.] These accounts are generally of somewhat ancient date, and not correspondent with the observations of later physicians. They were suited to those days of credulity, in which the Royal Society of London gravely inquired of Sir Philberto Vernatti, "Whether the Indians can "so prepare the stupifying 
herb Datura, that they make it lie several days, months, or years, according as they will have it, in a man's body; and at the end kill him without missing half an hour's time ?"?

Like opium and like other powerful medicines, this plant, when taken in small quantity, and under suitable regulations, proves a remedy of importance, and a useful agent in the hands of physicians. In common with some other narcotics, it seems first to have been introduced freely into practice by Baron Storck of Vienna, as a remedy in Mania, Epilepsy, Convulsions, \&g. Many subsequent physicians have given testimony to its efficacy in certain ferms of these disorders, yet the instances of its failure have doubtless been more frequent than those of its success. In Murray's Apparatus Medicaminum may be found a summary of the reports of many medical men, who have tried it with various success in the diseases in question, as well as in others. Dr. Cullen has no doubt that it may be a remedy in certain cases of mania and epilepsy ; but doubts if any person has learned to distinguish the cases to which it is properly adapted.

Dr. Fisher, President of the Massachusetts Medical Society, has published in their communications some remarks on the employment of Stra- 
monium in epilepsy. He divides the cases of that disease into three kinds; those of which the fits return daily; those in which they recur at regular periods, as monthly, or give warning of their approach by previous symptoms; lastly, those in which they do not observe any regular period, and do not give any warning of their approach. In the two first kinds he asserts, that all the cases which came under his care, and which were not very few, had been cured by Stramonium. In those of the third kind he found it of no benefit whatever.

Dr. Archer of Maryland has formed distinctions nearly similar in the application of Stramonium to epilepsy.

In a case of 'Tic doloureux of long standing $\mathbf{I}$ found the extract, taken in as large doses as the stomach would bear, to afford decided relief. Several practitioners have spoken to me of its efficacy in this formidable disease. It should be taken in large doses, and the system kept for some time under its influence.

Within a few years, the thorn apple has attracted much notice, both in Europe and in this country, as an efficacious palliative in Asthma and some other affections of the lungs, when used by smoking, in the same manner as tobacco. 
The practice was first suggested by the employment of another species, the Datura ferox, for similar complaints, in the East Indies. An English gentleman, having exhausted the stock with which he had been supplied of the oriental plant, was advised by Dr. Sims to have recourse to the common Stramonium as a substitute ; and upon trial, experienced the same benefit as he had done from the former species. This instance of success led to further trials, and in a short time several publications appeared, containing cases of great relief afforded by smoking this plant in the paroxysms of Asthma. Many individuals, of different ages, habits, and constitutions, had used it with the effect of producing immediate relief, and of terminating the paroxysm in a short time. The efficacy however of this medicine was called in question by Dr. Bree, a physician well known by his elaborate treatise on Asthma, who published in the Medical and Physical Journal a letter, containing the result of a great number of unsuccessful trials of Stramonium in asthmatic cases. It may be doubted whether any other physician has been so unfortunate in its use as Dr. Bree, since he affirms that not one case of those under his care was benefitted by it. Certain it is, that in this country the thorn apple is employed with 
very frequent success by asthmatic patients, and it would not be difficult to designate a dozen individuals in Boston and its vicinity, who are in the habit of employing it with unfailing relief in the paroxysms of this distressing complaint. The cases, which it is fitted to relieve, are those of pure spasmodic asthma, in which it doubtless acts by its sedative and antispasmodic effects. In those depending upon effusion of serum in the lungs, or upon the presence of exciting causes in the first passages, or elsewhere, requiring to be removed; it must not be expected that remedies of this class can afford benefit. In several cases of plethoric and intemperate people, I have found it fail altogether, and venesection afterwards to give speedy relief.

The part of the plant, which I have employed for smoking, is the leaf prepared in the same way as tobacco. The root, which has commonly been the part used, is more woody and fibrous, and possesses less of the juices of the plant, than its more pulpy and succulent parts. The root also, being strictly annual, has no opportunity to accumulate the virtues of the plant, beyond any other part.

In the seventh volume of the Medico-Chirurgical Transactions, for 1816 , is a paper on the 
properties of the Stramonium by Dr. Marcet of London, Physician to Guy's Hospital. As the result of his experience, it appeared that this medicine taken internally had relieved acute pains of various kinds more effectually than any other narcotic substance. Its usual effects under his observation, when administered in appropriate doses, in chronic diseases attended with acute pain; were, to lessen powerfully and almost immediately sensibility and pain; to occasion a sort of nervous shock, which is frequently attended with a momentary affection of the head and eyes, with a degree of nausea, and with phenomena resembling those produced by intoxication; to excite in many instances nervous sensations, which are referred to the osophagus or bronchiæ or fauces, and which sometimes amount to a sense like suffocation; to have rather a relaxing, than an astringent effect on the bowels ; to have no marked influence on the pulse, except in a few instances to seem to render it slower; to produce but a transitory and inconsiderable dilatation of the pupil, and to have but little immediate tendency to produce sleep, except from the state of comparative serenity and ease, which follows the preceding symptoms.-In some instances its beneficial effects were obtained without the patient experiencing any of the uneasy sensations above mentioned. 
The cases in which Dr. Marcet employed the Stramonium, with their results, appear in the following summary. In four cases of Sciatica, decided benefit was obtained. The effieacy of the medicine was still more strongly marked in two cases of sciatica combined with syphilitic pains. It failed in two instances of diseased hip joint. It produced considerable relief of pain in a case of supposed disease of the spine, followed by paraplegia; and likewise in one of eancer of the breast. It allayed materially the pain oceasioned by an acute uterine disease. It was of great and repeated utility in a case of 'Tic doloureux, its utility in a second case of the same deseription was very doubtful, and in a third it entirely failed.

There are some authorities for the success of Stramonium in Chorea. Professor Chapman of Philadelphia has found it of use in dysmenorrhea, also with or without mercury in syphilitic and scrophulous ulcers of ill condition.

The external use of Stramonium is of much older date than its internal exhibition. Gerarde in his Herbal, published in 1597, says, "The iuyce of Thorne apples, boiled with hog's grease to the forme of an unguent or salve, cureth all inflammations whatsoever, all manner of burnings or sealdings, and that in very short time, as my- 
self have found by my dayly practise, to my great credit and profit." Others, since the time of Gerarde, have used this preparation, if not with the same gratifying success, at least with some benefit as an anodyne, sedative application. It mitigates the pain in burns and inflammatory tumors, and promotes the cure of certain cutaneous eruptions. In some irritable ulcers with thickened edges and a sanious discharge, $I$ have found it remarkably efficacious in changing the condition and promoting the granulations and cicatrization. In painful hemorrhoidal tumors the ointment of Stramonium with the ointment of acetate of lead gives, in many cases, very prompt and satisfactory relief, being in this respect inferior to no application, with which I have been acquainted.

Applied topically to the eye, the preparations of Stramonium diminish the sensibility of the retina, and relax the iris. From this effect it is employed by many surgeons to dilate the pupil, as preparatory to the operation for cataract.

The virtues of Stramonium appear to be seat. ed in an extractive principle, which dissolves in water and alcohol, but most readily in the former. It is copiously precipitated from the infusion by muriate of tin. With sulphate of iron it gives a deep green colour, and with gelatin suf- 
fers no change. Water distilled from the plant has the sensible qualities in a slight degree, but does not seem to possess the medicinal powers of the plant. Dr. S. Cooper, in a valuable dissertation on this plant, says, that an ounce of the distilled water was taken into the stomach with little or no effect. The same gentleman states, that upon evaporating the infusion of Stramonium, he observed a large number of minute erystals, resembling particles of nitre. Thinking it possible that these might be something analogous to the crystals, said to be obtained by Derosne from opium, and by him denominated the narcotic principle, I repeated the experiment by carefully evaporating separate decoctions of the green and dried leaves. No crystals however were discoverable at any stage of the process, either to the touch, or to the eye assisted by a strong magnifier.

The forms in which the Stramonium is prepared for use are the powder, the inspissated juice, the extract, the tincture and the ointment. The porvder should be made as soon as the plant is dry, and kept in close stopped bottles.-The inspissated juice is made by compressing the bruised leaves in a strong bag, until the juice is forced out. This is to be evaporated in flat vessels at 
the heat of boiling salt water to the thickness of honey; it is then suffered to cool, put up in glazed vessels and moistened with alcohol. The extract is prepared by immersing a pound of the leaves in three gallons of water and boiling down to one. The decoction should then be strained and stand six hours to settle, after which it may be drawn off and evaporated to the proper consistence. When the seeds are used, the decoction should stand a longer time to separate the oil with which the cotyledons abound, before evaporation. A larger amount of extract may be obtained by boiling the portion, which has been used, a second time in a smaller quantity of water, and mixing the two decoctions before evaporation. For the tincture one ounce of the dried leaves is to be digested for a week in eight ounces of proof spirit, and filtrated through paper. In making the ointment, a pound of the fresh leaves may be simmered in three pounds of hog's lard until the leaves become crisp. It is then to be strained, and cooled gradually.

The period for gathering the leaves is from the time the plant begins to flower, until the arrival of frost.

As the preparations of Stramonium are liable to vary in strength according to the circumstances 
under which they are made, it is always prudent to begin with the smallest dose, and repeat it about three times a day, increasing each dose until the effects begin to appear in the stomach or head.

The commencing doses of the Stramonium, when properly prepared, are as follows. of the powdered leaves powdered seeds 1 grain. inspissated juice or extract 1 grain. extract of the seeds from $\frac{x}{4}$ to $\frac{x}{2}$ grrain. tincture

from 15 to 20 drops.

BOTANICAL REFERENCES.

Datura Stramonium, Linneus Sp. pl. Fl. Suec. $185 \& c$ Gronovius Fl. Virg. 23.-CEder. Fl. Danica 436.-Blackweil $t$. 313.-Gmenin Iter i. 43.-Politch. Palatin. 224.HoffMann Germ. 77.-Roth Fl. Germ. i. 92 \&c.-Woodvmue t. 124.-Curtis Lond. vi. t. 17.-Sмith Fl. Brit. 254.-Engl. Bot. t. 1288.-Pursh Amer. 141.-Eunite Carol. i. 275.Stramonium foliis angulosis \&c. HALLER Helv. 586. Nuci metellæ congener planta, Camerarius Epitome 276.-Solanum foetida pomo spinoso, oblongo, \&c. BAUHIN pin. 168.-Stramonium spinosum, Gerarde Herbal 348.

\section{MEDICAL REFERENCES.}

Storck de Stramonio \&o.-LindenstoLPe de venenis, 531.Sadvages Nosol. 2. 430.-Greding in Ludwigs Adversaria i. 345.-Murray App. Med.i. 670.-Culuen Mat. Med. ii. 281.Fowler in .Med. Comment. v. 161.-ODhrenus cit. in .Med. Comment v. 161,-Papin in Phil. Trans. abr. vi. 53.-Rush in Philad. 
Trans. i. 384.-Schoepf. 24.-Wenenberg in .Med. Comment iii. 18.-Beverux, Hist. Virg. p. 121.-Medical and Physical Journal, vol. xxv. \& xxvi. in various places. Cooper in Caldwell's Theses, vol. i.-Barton, Coll. Mat. .Med.46.-Chapman in edit. Murray 146.-Thatcher, Disp. 205.-Marcet .Medico-Chimur. Trans. vii.

\section{PLATE I.}

Fig. 1. A branch of Datura Stramonium, the purple variety, with leaves and flowers.

Fig. 2. Stamens and style.

Fig. 3. Transverse section of the pericarp, shewing the cells, receptacles and seeds. 


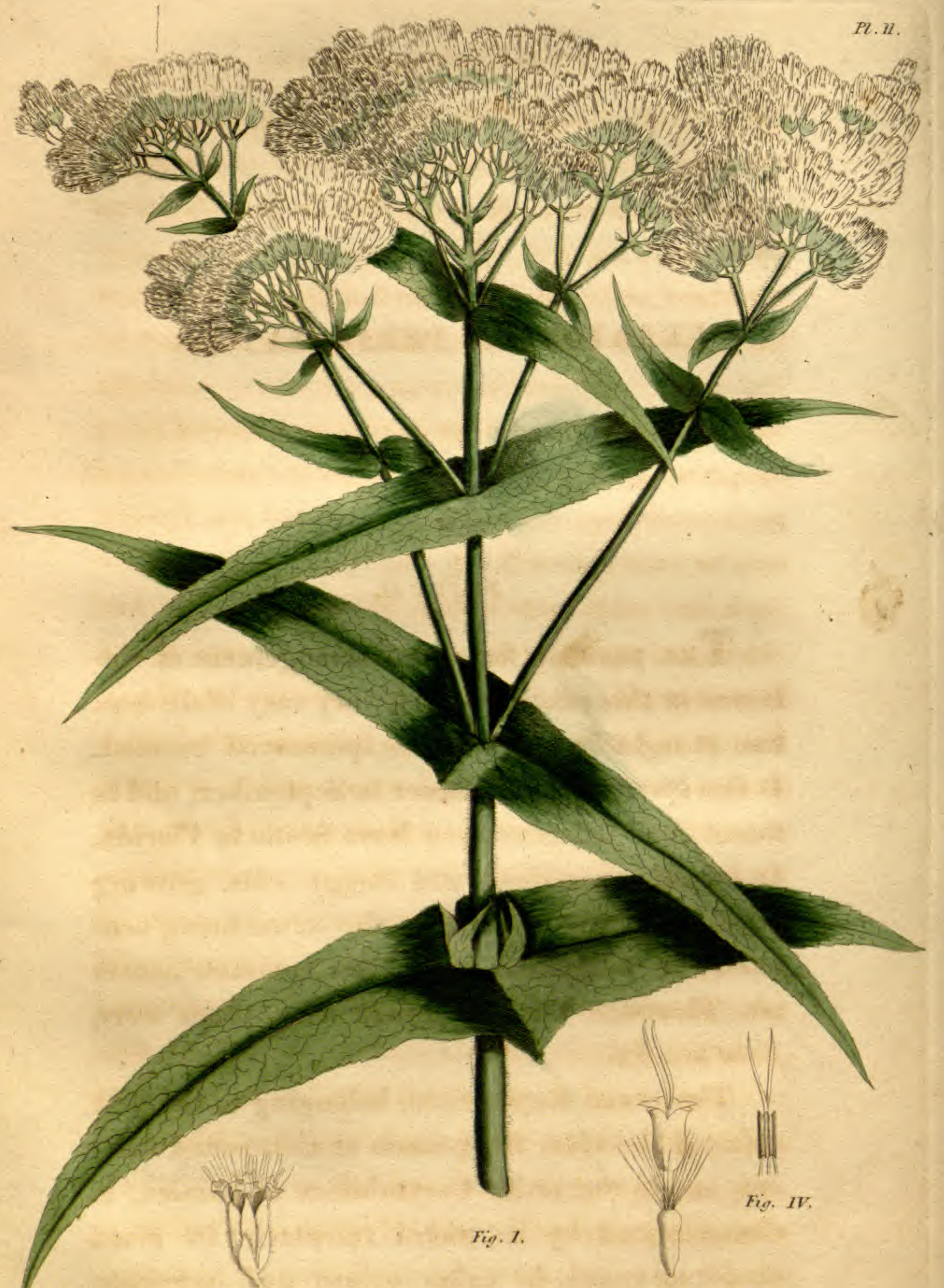

Fig. II. 


\title{
EUPATORIUM PERFOLIATUM.
}

\author{
Thorough wort.
}

PLATE II.

$\mathbf{T}_{\text {He peculiar form and arrangement of the }}$ leaves in this plant render it very easy of distinction at sight by the most inexperienced botanist. It flowers from midsummer to September, and is found in all latitudes from Nova Scotia to Florida. It inhabits meadows and boggy soils, growing most frequently in bunches, the stems being connected by horizontal roots. Its common names are Thorough wort, Thorough wax, Cross wort, Bone set, \&.c.

The genus Eupatorium, belonging to the first order of the class Syngenesia or Compound flowers, and to the order Corymbiferæ of Jussieu, is characterized by its naked receptacle, its down simple or rough, its calyx oblong and imbricate, 
tially subsided in a short time.-In distillation, water came over very slightly affected with the sensible qualities of the plant, and not alterable by sulphate of iron.

A dissertation of merit on this plant was published a few years since by Dr. Anderson of New York, in which he gives the details of numerous and elaborate chemical trials, made by him on different parts of the plant. He concludes, among other things, from his experiments, that the active properties of the plant reside in greatest quantity in the leaves, and that its virtues are readily obtained by means of a simple decoction.

The medical powers of Eupatorium are such as its sensible properties would seem to indicate, those of a tonic stimulant. Given in moderate quantities, either in substance or in cold infusion or decoction, it promotes digestion, strengthens the viscera, and restores tone to the system. Like other vegetable bitters, if given in large quantities, especially in warm infusion or decoction, it proves emetic, sudorific, and aperient. Even in cold infusion it tends to bring on diaphoresis.

This plant has been lon' in use in different parts of the United States, for the same purposes for which the Peruvian bark, Gentian, Chamomile, S.c. are employed. It has been found competent 
to the cure of intermittent fevers by various practitioners in the middle and southern states. Dr. Anderson has detailed six cases of intermittents, quotidian, tertian, and quartan, out of a large number which had been successfully treated within his own observation by the Eupatorium both in substance and decoction. In these cases the cures were certainly expeditious, and took place at as early a period as could have been expected from arsenic or the Peruvian bark. Dr. A. cites the experience of several distinguished practitioners, particularly Dr. Hosack of New York and the late Dr. Barton of Philadelphia, in confirmation of his own, to shew that the Eupatorium is an efficacious remedy in the treatment of various febrile disorders, also of many cutaneous affections, and diseases of general debility.

I have prescribed an infusion of the Eupatorium in various instances to patients in the low stages of fever, where it has appeared instrumental in supporting the strength and promoting a moisture of the skin, without materially increasing the heat of the body. I have also found the cold infusion or decoction a serviceable tonic in loss of appetite and other symptoms of dyspepsia, as well as in general debility of the system. 
The warm infusion is a convenient substitute for that of chamomile flowers in facilitating the operation of an emetic.

When employed as a tonic, this plant may be taken in powder in doses of twenty or thirty grains, or a teacup full may be used of the infusion, rendered moderately bitter. When intended to act as an emetic, a strong decoction may be made from an ounce of the plant in a quart of water, boiled to a pint.

\section{BOTANICAL REFERENCES.}

- Eupatorium perfoliatum, Linnzus, $S p$. pl.-Aiton, Hort. Kew. iii. 160.-WILldenow, $S p$. $p l$. iii. 1761.-Gronovius, Virg. 119.-Colden, Novebor. 181.-S ToKes, iv, 171.-PURsH, ii. 516.-Eupatorium connatum, Мrснашx, Fl. Amer. ii. 99.Eupatorium Virginianum, \&c.-Plekenet, $t$. 87.f. 6.-Rarus, suppl. 189.-MoRIson, hist. iii. 97.

\section{MEDICAL REFERENCES.}

Schoepf 121.-Guthrie in Annal. Med. iii. 403.-Bart. Coll. 28. -Med. and Phys. Journal.-Thacher Disp. 217.-ANDERson, Inaugural Thesis.

\section{PLATE II.}

Fig. 1. Eupatorium perfoliatum.

Fig. 2. A flower magnified.

Fig. 3. A floret magnified.

Fig. 4. Tube of anthers with the style running through. 


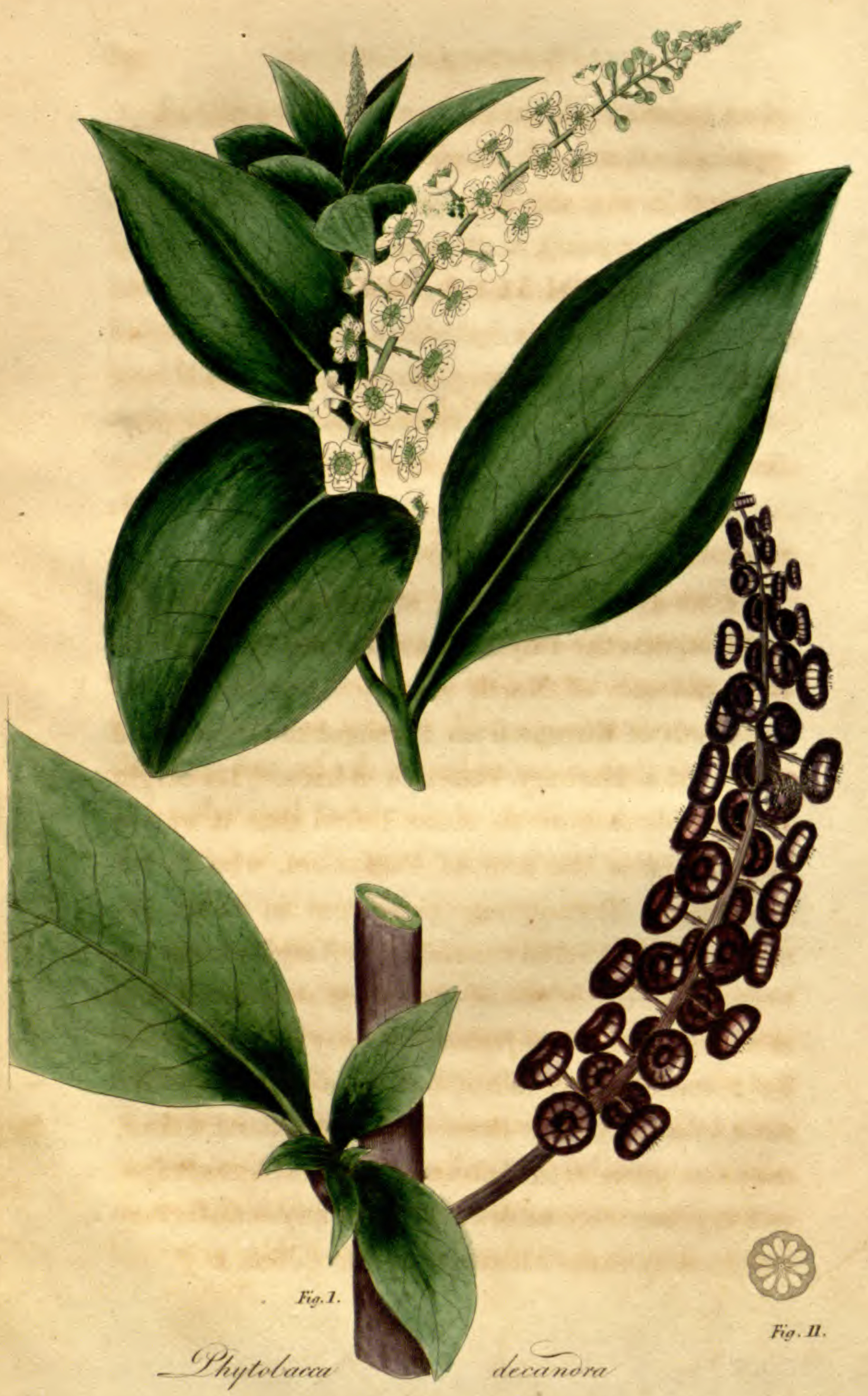




\section{PHYTOLACCA DECANDRA.}

Poke.

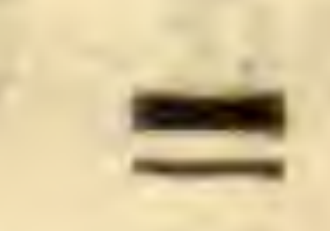

PLATE III.

From the testimony of different writers it appears, that the Phytolacea decandra is an inhabitant not only of North America, but likewise of the south of Europe from Portugal to Greece, and also of the Barbary states in Africa. Its origin is probably American, since I find that it was so considered in the time of Parkinson, who in his Theatrum Botanicum, published in 1640 , denominates it "Solanum magnum Virginianum rubrum." This is one of the oldest accounts I find of it. Plukenet conjectures it may be the Cuechiliz tomatl of Hernandez, but the description, like most others of that loose and superficial writer, are more promotive of obscurity than of knowledge, and it is not easy to draw from it any satisfactory evidence as to its Mexican origin. [.Note D.] 
In the autumnal months no plant among us is more remarkable than the Phytolacca for its large size, and the fine colour of its clusters of berries. Its most general appellation is Poke, an abbreviation, perhaps, of Pocan, the name by which it was known in Virginia a century ago. In New England it is more frequently called Garget, Cocum, Jalap and Pigeon berries.

Jussieu has arranged this genus among his Atriplices, and Linnæus with the Oleracea.

The number of its stems and styles, place it in the class Decandria and order Decagynia. Its generic character consists in having no calyx, a corolla of five petals, and its berries superior with ten cells and ten seeds. The species decandra is the only one which strictly agrees with its class and order, and is known by having ovate leaves, acute at both ends, and its flowers with ten stamens and styles.

The root of this plant is of large size, frequently exceeding a man's leg in thickness, and is usually divided into two or three principal branches. Its substance is fleshy and fibrous, and easily cut or broken. Internally it is distinctly marked with concentric rings of considerable thickness, while its outer surface is covered with a very thin brownish bark, which seems to be little more than a cu- 
ticle. The stalks, which are annual, frequently grow to the height of six, and even nine feet. They are round, smooth, and very much branched. When young, their usual colour is green, but in most plants, after the berries have ripened, they are of a fine purple. The leaves are scattered, petioled, ovate-oblong, smooth on both sides, ribbed underneath, entire, acute. The flowers grow on long pedunculated racemes opposite to leaves. Peduncles nearly smooth, angular, ascending. Pedicels divaricated, sometimes branched, green, white, or purple, furnished with a small linear bracte at base, and two others in the middle. Calyx none. Corolla resembling a calyx, whitish, consisting of five round-ovate, concave, incurving petals. Stamens ten, rather shorter than the petals, with white, roundish, two lobed anthers. Germ greenish, round, depressed, ten furrowed. Styles ten, short, recurved. The flowers are succeeded by long clusters of dark purple berries, almost black, depressed or flattened, and marked with ten furrows on the sides.

The dried root is light coloured and spongy, with a mild and somewhat sweetish taste. A part of it is soluble both in water and alcohol, and neither of these substances renders turbid the solution in the other, unless the solution has been in- 
spissated by long boiling. The soluble portion ap" pears neither resinous nor mucous. It approaches most nearly to extractive, but has characters somewhat peculiar to itself. A decoction of the root procured by boiling for ten minutes in distilled water, exhibited after filtration the following results. It was transparent, nearly colourless, and did not alter litmus. It gave no precipitate with the sulphuric, nitric, muriatic, oxymuriatic, and acetous acids. It gave no precipitate with the sulphate of iron, but formed a copious one with the nitrates of mercury and silver, and the acetate of lead. Muriate of tin produced no effect at first, but after standing, a light precipitate took place. Pearl ash, lime water, and muriate of barytes rendered the solution turbid. Acetate of barytes occasioned no change. Oxymuriate of lime formed an immediate precipitate.

The cold infusion exhibited nearly the same results as the decoction. The alcoholic solution underwent no change from muriate of tin, but threw down a dense precipitate with nitrate of mercury.

From the above experiments it appears, that the soluble principle of the Phytolacea differs from common vegetable extractive, as defined by the chemists, in several respects, particularly in 
not being thrown down by the oxymuriatic or other mineral acids, and in being but partially affected by muriate of tin.

In the Annales de Chimie, vol. Ixxii, is a memoir on the Chemical properties of the Phytolacea decandra by M. Braconnot. His experiments indicate the presence of an unusual quantity of vegetable alkali in this plant. He found that the ashes, procured by incinerating the stalks, afforded nearly 67 per cent. of dried alkaline carbonate, and 42 per cent. of pure caustic potash. This alkali in the plant is neutralized by an acid having considerable affinity to the malic, but with a few shades of difference. With lime and lead malic acid forms flocculent precipitates, very easily soluble in distilled vinegar, but those with the phytolaccic acid are insoluble. M. Braconnot thinks this acid may probably be a mean between the malic and oxalic acids, or an oxygenized malic acid.

The same memoir contains an examination of the colouring matter in the berries of the Phytolacca. The juice of these berries is of a very fine, bright purple colour, but this colour is extremely fugacious and disappears in a short time from cloth or paper that has been tinged with it. A few drops of lime water added to this purple 
juice change it to a yellow colour, but the smallest quantity of acid is sufficient to restore its purple hue. Exposure to the air or large dilutions is sufficient to restore the original purple.

M. Braconnot considers the yellow liquor produced by the juice of these berries and lime water as one of the most delicate tests of the presence of acid. Into two glasses he put equal quantities of the juice made yellow and of an infusion of litmus of equal depth of colour. More than sixty drops of a very weak acid were required to redden the infusion of litmus, but less than fifteen restored the purple colour of the Phytolacea. Hence it follows, that the yellow liquor is four times as sensible to the presence of acid, as the infusion of litmus. It however requires to be used immediately after it is prepared, since a few hours cause a spontaneous change in it, which begins with a precipitate, and ends with a deprivation of colour.

The effects produced on this purple colour by other reagents were as follows. Pure alkalis gave it a yellow colour. Alkaline subcarbonates a violet, that fades and becomes yellow by standing. Weak acids no perceptible change. Dilute oxymuriatic acid a complete deprivation of colour with white flocculi. Alum nothing at first, but 
after some days, a very light red precipitate. Muriate of lime no change. Muriate of tin a red sediment inclining to lilac, leaving the fluid colourless. Nitrate of lead a precipitate of the colour of wine lees. Super oxided sulphate of iron, a dirty violet.

Many of the above experiments $I$ have repeated, and added others. The yellow colour produced by the alkalis borders on green. Pure strontian produces the same change as potash and lime. Pure barytes wholly discharges the colour on standing a short time. Acetate of lead forms a scarlet precipitate, leaving the liquid nearly colourless.

The purple colour that tinges the cuticle of the stalks of the Phytolacea is stated in the above memoir, to be of the same nature as that in the berries, and to afford the same results.

The taste of the berries is sweetish and nauseous, leaving behind a very slight sense of acrimony. M. Braconnot, found that at a moderate temperature, the juice underwent the vinous fermentation, and yielded alcohol by distillation. Dr. Shultz procured from half a bushel of the berries six pints of spirit sufficiently strong to take fire and burn with readiness. 
In its medicinal properties the root of the Phytolacca decandra approaches nearer to ipecacuanha than any American vegetable, I have hitherto examined. From abundant experience, the result of many trials made in Dispensary practice, I am satisfied that, when properly prepared, it operates in the same doses and with the same certainty, as the South American emetic. Ten grains of the powder will rarely remain on the stomach, and twenty or thirty produce a powerful operation, by emesis and generally by catharsis. In its mode of operation, this medicine has some peculiarities, a part of which are favorable, others disadvantageous. Its advantages are, that it operates with ease, and seldom oceasions pain or cramp. Its disadvantages are, 1. That it is slow in its effects, frequently not beginning to operate until an hour, and sometimes two hours after it is taken. 2. That it continues to operate for a greater length of time than is usual for emetics, although as far as I have been able to observe, it is readily checked by an opiate. These disadvantages however are not constant. I have repeatedly known it commence operating in fifteen minutes, and cease after four or five ejections. The representations of patients as to any unpleasant feelings under its effects, are not greater than we should 
naturally expect, when it is recollected, that no emetic is altogether comfortable in its operation. Dr. Fisher of Beverly* informs me that whenever he has used the Phytolacca, it has performed its duty as an emetic perfectly well, and that in one patient, a female of irritable stomach, in whom previous emetics had always excited severe spasms, ten grains of the Phytolacea operated effectually, and no spasm followed.

I have sometimes observed slight narcotic symptoms during the operation of Phytolacea, particularly vertigo. But others have not always met with this symptom. Dr. George Hayward of this town, who has had much experience with this medicine, the results of which were communicated to the Linnæan society, and afterwards published in the New England Journal, October 1817, states that in doses of a scruple, he never noticed any dizziness, or stupor from it, although he had always been particular in his inquiries to know if any such symptoms took place. The above dose was administered by him in nearly thirty cases, in all of which, except in one case, it operated as an emetic and cathartic, usually three or four times, thoroughly, though not severely, generally commencing its operation on the stom-

* Letter dated November, 1815. 
ach in an hour, and rarely continuing longer than four. He found it to excite little or no nausea previous to its operation, and though it made a powerful impression on the system, it never produced any disagreeable or unusual symptoms.

Dr. Hayward also made trial of the powder of the leaves, which he found to possess the same properties with that of the root, but to be less effectual and less certain in its operation. He also prepared a tincture, decoction, and wine of the root; but all these were inferior to the medicine in substance, being less certain in their effect, and sometimes giving rise to troublesome symptoms.

Dr. Shultz of Pennsylvania, author of an inaugural dissertation on the Phytolacca decandra, gave the expressed juice of the leaves, berries, and roots, in considerable quantity to animals. It operated by emesis and eatharsis, attended with drowsiness. The juice of the root was most active. He also gave to a dog two ounces of the spiritous liquor distilled from the berries. It occasioned nausea and drowsiness, with slight spasmodic motions, but no vomiting.

In the same dissertation, Dr. Shultz refers to several instances of persons who had incautiously eaten large quantities of the root through mistake. Its effects were violent vomiting and purging, 
prostration of strength, and in some instances convulsions.

The Phytolacca has had some reputation in the treatment of rheumatism. Dr. Griffits, formerly a professor in the University of Pennsylvania, found it of great use in Syphilitic rheumatism. Dr. Hayward however states, that he derived no advantage from its employment in rheumatic affections.

The young shoots of this vegetable are destitute of medicinal qualities, and are eaten in the spring in some parts of the United States, as substitutes for asparagus. At this time the succus proprius or returning juice of the plant is not yet formed by exposure of the sap to the atmospheric air, in the leaves. The ripe berries are less noxious than the green, and are devoured by several species of birds. In Portugal and in France they were formerly employed to improve the colour of red wines, until the interference of government became necessary to put a stop to the practice.

The external application of Phytolacca has been found useful in a variety of cases, by its action as a local stimulant. The ointment and extract have commonly been employed for this purpose. These preparations usually excite a sense of 
heat and smarting on being first applied. I have cured cases of psora with the ointment, and Dr. Hayward states, that he found it successful in cases where sulphur had failed. A case of tinia capitis of twelve years' standing, which had resisted various kinds of treatment, was also cured by this application.

The Phytolacca is one of those vegetables which has had its temporary reputation for the cure of cancer. For this purpose it has been resorted to in various parts of the world, and many men of science have been convicts to its efficacy, among whom were Dr. Colden and Dr. Franklin of our country. [Note E.] But like other vegetable specifies for cancer, it owes its character to an imperfect discrimination of that disease, and a misapplication of the name. All that can be strictly inferred from the various accounts we have had on this subject, is, that the plant has often proved useful in malignant ulcers by its stimulating and almost escharotic effects, frequently producing an eschar, and thus altering the condition of the ulcerated surface.

For internal use no preparation of the Phytolacea is to be preferred to the powder, of which from ten to fifteen grains is often a sufficient emetic. 
The root should be dug late in autumn or during the winter. It should be cut in transverse slices and dried. After being pulverized, it should be kept in close stopped phials. The stock should be annually renewed, as its activity is impaired by age.

\section{BOTANICAL REFERENCES.}

Phytolacca decandra, Linneus, sp.pl.-Aiton, Hort. Kew. ii. 122.-Botanical Magazine, $t$. 931.-Michaux, Fl. Amer. i. 278. Pursh. i. 324.-Phytolacca vulgaris, Dimlenius, Hort. Elth. t. 239.-P. Americana-Boerhanve, Hort. Lug. ii. 70.-Solanum racemosum Americanum, Raids, Hist. 662.-Plukenet, Phyt. $t$. 225. f. 3.-Solanum magnum Virginianum rubrum, Parkinson, Theatrum, 347.-Blitum Americanum, MuntivGIUs, Phyt. cur. t. 212.

\section{MEDICAL REFERENCES.}

Murray, appar. med. iv. 335.-KaLM, travels in .N. Amer. i. 197.-Graffenreid, Mem. Berne, iii. 185.-Schopp. 71.Browne, Hist.Jamaica, 232.—Amoen. Acad. iv.-MTHER, Dictunder the name.-SPRogex. Diss. cir. ven. 24.-BeckMan, comment. Gotting. 1779, 74.-Aulioni, Flor.Ped. ii. 132.-FranKuIv, works, vol. i.-Cutuer, Mem. Amer. Acad. i. 447.-Rush, i. 259.-Thacher, Disp. 300.-Shultz, Inaugural thesis.HAXWARD, N. Engl. Journal, vi.

\section{PLATE III.}

Fig. 1. Phytolacca decandra in flower and in fruit.

Fig. 2. Section of a berry. 


\title{
ARUM TRIPHYLLUM.
}

\author{
Dragon root.
}

\section{=
PLATE IV.}

$I_{\mathrm{T}}$ appears, that both North and South America give rise to this species of Arum, which is so versatile in its constitution as to bear the winters of Canada, and the perpetual summer of Brazil. In its structure it is one of our most singular vegetables, and in colour one of the most variable. It grows in swamps and damp shady woods, and is universally known among us by the names of Dragon root and Indian turnip.

The class to which the family of Arums belong, is rendered somewhat obscure by the variation of the species. Most botanists have placed them in the class.Moncecia, others in Polyandria. The species under consideration is undoubtedly Polygamous. In natural arrangements, the Arums 


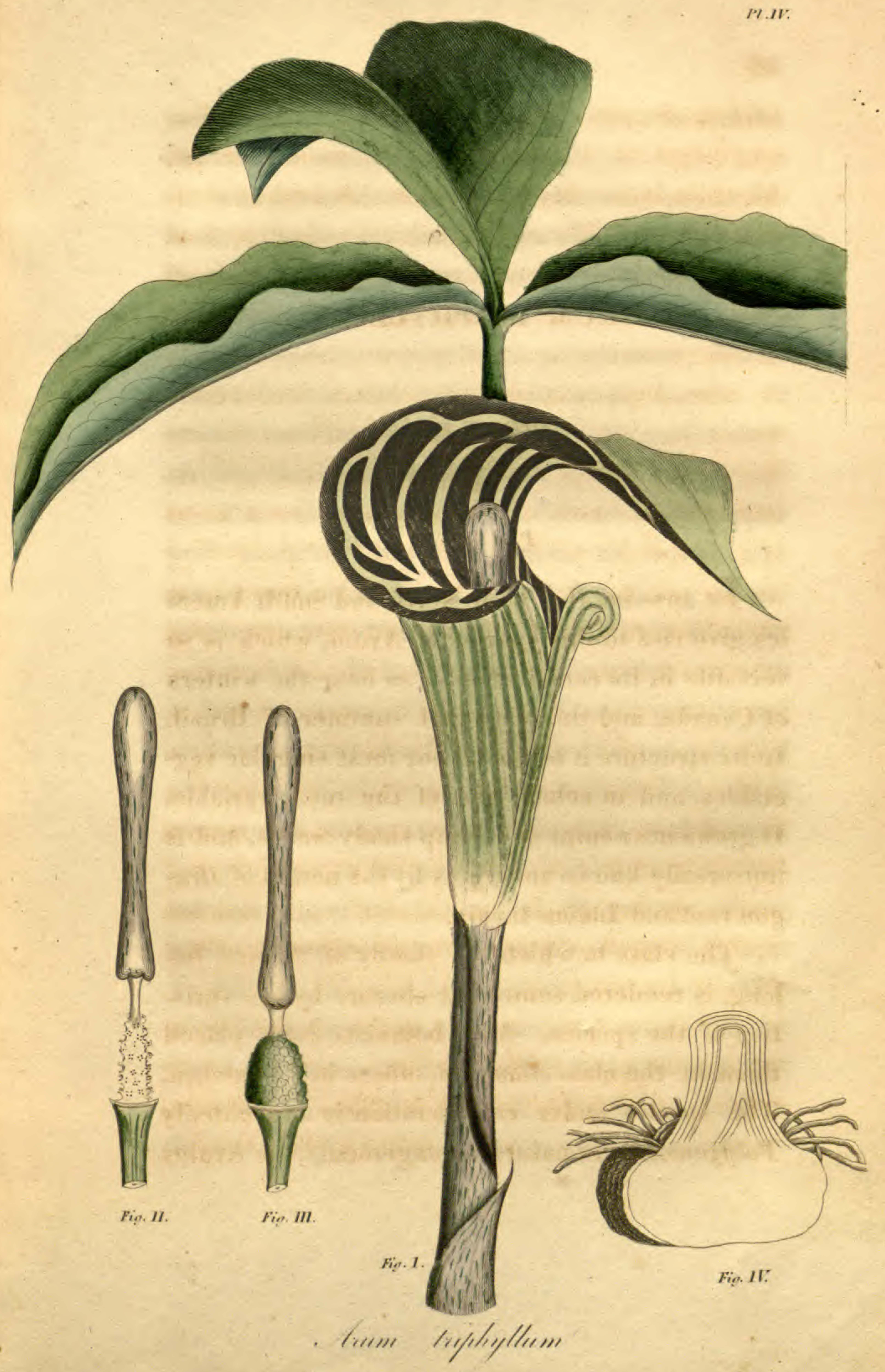


are found under the Piperite of Linnæus and the Aroidea of Jussieu. Aracenci Gray.

The genus Arum may be characterized as follows. Spathe one leaved, convolute at base; spadix naked above, bearing the organs of fructification at base; berries one celled.

The species triphyllum is polygamous; has its leaves ternate and entire; its scape bearing an ovate, acuminate, inflexed spathe; its spadix clubshaped, shorter than the spathe.

The root is round and flattened, its upper part tunicated like the onion, its lower and larger portion tuberous and fleshy, giving off numerous long white radicles in a circle from its upper edge. It is covered on the under side with a dark, loose, wrinkled skin. Leaves usually one or two on long sheathing footstalks, composed of three oval, mostly entire, acuminate leafets, which. are smooth, paler on the under side, and becoming glaucous as the plant grows older, the two lateral ones somewhat rhomboidal. Scape erect, round, green or variegated with purple, invested at base by the petioles, and by their acute sheaths. This supports a large, ovate, acuminate spathe, convoluted into a tube at bottom, but flattened and bent over at the top, like a hood. Its internal colour is exceedingly various, even in plants growing to- 
gether. In some it is wholly green, in others dark purple or black. In most it is variegated, as in our figure, with pale greenish stripes on a dark ground. The spadix is much shorter than the spathe, club shaped, rounded at the end, green, purple, black, or variegated, suddenly contracted into a narrow neck at base, and surrounded below by the stamens or germs. In the barren plants, its base is covered with eonical, fleshy filaments, bearing from two to four circular anthers each. In the fertile plants, it is invested with roundish crowded germs, each tipt with a stigma. Plants which are perfectly monœcious, and which are the least common, have stamens below the germs. There are also frequently found irregular, reniform substances, much larger than the anthers, of which they seem to be a disease. The upper part of the spadix withers with the spathe, while the germs grow into a large compact bunch of shining scarlet berries.

Every part of the Arum, and especially the root, is violently acrid, and almost caustic. Applied to the tongue or to any secreting surface, it produces an effect like that of Cayenne pepper, but far more powerful, so much so, as to leave a permanent soreness of many hours' continuance. Of this any one may become satisfied by a simple 
application of the root to his mouth. Its action does not readily extend through the cuticle, since the bruised root may be worn upon the external skin until it becomes dry, without occasioning pain or rubefaction.

The acrid property, which resides in this and other species of Arum, appears to depend upon a distinct vegetable principle in Chemistry, at present but little understood. It is extremely volatile, and disappears almost entirely by heat, drying, or simple exposure to the air. I have endeavoured, with but partial success, to obtain it in a separate state, or in any perceptible combination. The following were some of the methods by which it was attempted.

Portions of the fresh contused root were separately digested in water, in proof spirit, in alcohol, in ether, in olive oil and in vinegar. The infusions were tasted at different periods, but none of them had acquired the least acrimony from the plant.

The expressed juice of the root upon standing one minute had lost all its pungency.

A quantity of the bruised root was placed in a retort and covered with water. Heat was gradually applied, until a fluid began to collect in the receiver. This fluid had the peculiar odour of 
the root, but was wholly without acrimony. The same experiment was repeated with alcohol, and vinegar, and afforded similar results. In every case the liquid remaining in the retort was also without pungency.

Some slices of the root were digested in proof spirit in a close stopped phial. The portions of root retained their acrimony at the end of some weeks, but had imparted none to the spirit. At the end of two years, the root was examined and found destitute of acrimony, as were also the whole contents of the phial.

Suspecting that the acrid principle of this plant must escape in form of gas during the processes which have been mentioned, the following experiment was made. A quantity of the bruised root and stalks were placed in a vessel of water. A glass receiver was filled with water and inverted over them, and sufficient heat applied to raise the water nearly to the boiling point. From the beginning of the process, bubbles of air continued to escape from the plant, and were collected in the upper part of the receiver. In the course of half an hour, a considerable quantity of permanent gas was obtained. A part of this gas, after cooling, was transferred to a phial, in which was a small quantity of atmospheric air. On pre- 
senting a lighted paper to the mouth of this phial, it exploded with a very distinct report. Another portion of the gas was agitated with lime water, which it rendered turbid. This circumstance was probably owing to the mixture of carbonic acid disengaged from the plant, or from the water by boiling.

From the above experiments, which circumstances did not permit me to pursue, it appears that the acrimony of the Arum resides in a principle having no affinity for water, alcohol, or oil, being highly volatile, and, in a state of gas, inflammable. The products of its combustion, as well as its other affinities, remain to be investigated.*

The acrimony of the Arum when fresh is too powerful to render its internal exhibition safe. The roots, when dried whole, retain a small portion of their pungency, and in this state they have been given by some practitioners in the country for flatulence, cramp in the stomach, \&c. also for

* The acrimony of the Ranunculi, which approaches that of the Arum, is lost by drying, yet is soluble in water, and passes over with it in distillation. That of Polygonum hydropiper disappears in decoction and distillation. The same takes place with several other acrid plants which $I$ have examined. Some inquiries into the acrid principle of vegetables $\mathrm{I}$ am in hopes to render more mature at a future period. 
asthmatic affections. As topical stimulants, they promise to be useful when any method shall have been discovered of fixing and preserving their acrimony. The late Dr. Barton of Philadelphia observes, that " the recent root of this plant boiled in milk, so as to communicate to the milk a strong impregnation of the peculiar acrimony of the plant, has been advantageously employed in cases of consumption of the lungs." This statement however should be qualified by the recollection, that the Arum imparts none of its acrimony to milk upon boiling. An impression of this kind can only have been received from a partial mixture of the substance of the root with the milk.

The root contains a large proportion of very pure white frecula, resembling the finest arrow root or starch. To procure this, the fresh root should be reduced to a pulp, and placed on a strainer. Repeated portions of cold water should then be poured on it, which in passing through the strainer carry with them the farinaceous part, leaving the fibrous portion behind. The fæcula thus obtained, loses its acrimony on being thoroughly dried, and forms a very white, delicate and nutritive substance. Dr. M'Call of Georgia found these roots to yield one fourth part of their weight of pure amylaceous matter.-It is not uncommon 
for a nutritious fæcula to exist in pungent and poisonous roots. The Laplanders prepare a wholesome bread from the acrid roots of Calla palustris, and the juice of the Cassava, or bread root tree of the West Indies, is known to be highly deleterious while recent. [Note F.]

\section{BOTANICAL REFERENCES.}

Linnaus, $s p$. pl.-WILLDenow, iv. 480.-Aiton, Hort. Kew. îi. 315.-Walter, Carol. 224.-Michaux, Fl. ii. 188.-Pursh, ii. 399. Dracunculus s. Serpentaria triphylla, \&c.-Bavein, Pin. 195.-Arum s. Arisarum, \&c.-Morison, Hist. iii. 547, s. $13, t .5$.-Plukenet, $t .77, f .5$. also $t .376, f$. $s$.

\section{MEDICAL REFERENCES.}

Schopp, Mat.Med. 133.-Rush, ii. 301.-Barton, Coll. 29, \&c.-M'C CаI, in Philad.Med. and Phys. Journal, ii. 84.-ТнаснER, Disp. 153.-Cutrer, Mem. Amer. Acad. i. $48 \%$.

\section{PLATE IV.}

Fig. 1. Arum triphyllum.

Fig. 2. Spadix with anthers.

Fig. 3. Spadix with germs.

Fig. 4. Longitudinal section of the root. 


\title{
COPTIS TRIFOLIA.
}

\author{
Gold thread.
}

\section{$=$ \\ PLate $V$.}

The dark sphagnous swamps, which in the northern parts of our continent are covered with a perpetual shade of firs, cedars and pines, are the favourite haunts of this elegant little evergreen. The coldest situations seem to favour its growth, and it flourishes alike in the morasses of Canada and of Siberia. On our highest mountain tops it plants itself in little bogs and watery clefts of rocks, and perfects its fructification in the short summer allowed it in those situations. I have gathered it upon the summit of the Ascutney in Vermont, and on the Alpine regions of the White mountains. It is here that in company with the Diapensia and Azaleas of Lapland, the blue Menziesia, the fragrant Alpine Holcus, and other plants 
PI.V.

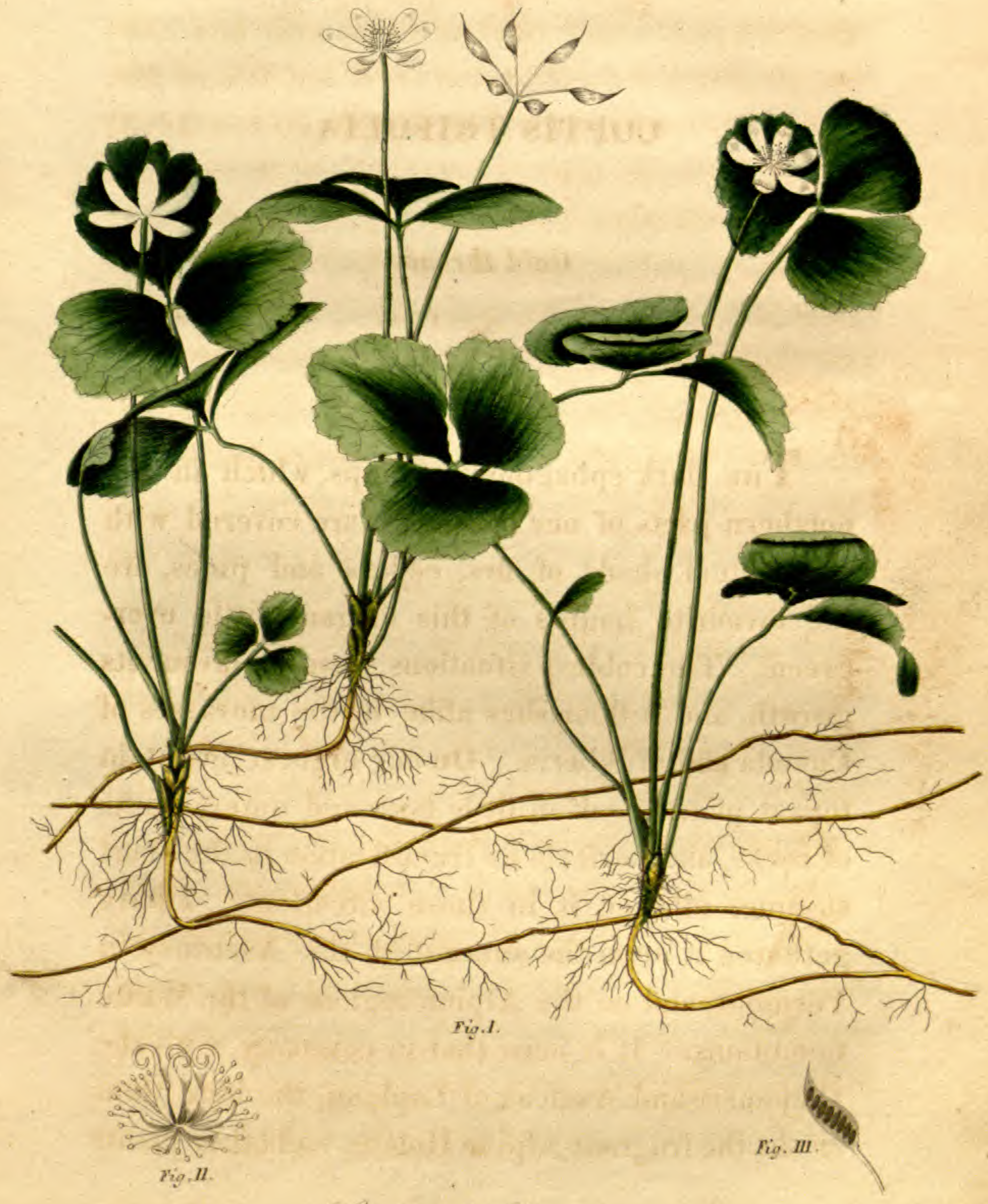

Coplie tripolin 
of high northern latitudes, it forms the link of botanical connexion between the two continents. When in situations like this, we seem transported to the frigid zone, and to be present at the point where the hemispheres approach each other, as if to interchange their productions.*

In the second volume of the Amcenitates Academica is a description and imperfect figure of this plant as brought from Kamschatka, by Halenius. He describes it by the name Helleborus trifolius, with the observation, "Minima est hæc planta in suo genere, attamen spectabilis." Subsequent botanists have ranked it with the Hellebores, until Mr. Salisbury very properly separated it from a family of plants, with which it wholly disagrees in habit, and constituted a new genus by the name of Coptis. This genus is characterized by the following marks. Calyx none; petals five or six, callucous; nectaries five or six, cucullate; capsules from five to eight, pedicelled, beaked, many seeded. The species trifolia has ternate leaves, and a one flowered scape.

* "Non sine admiratione vidi non solum multas cum rarissimis nostris plantis Lapponicis communes, sed etiam alias, partim ignotas omnino, partim minime tritas ; et denique quasdam etiam cum Canadensibus easdem, argumento Canadam a Camscatca non longe dista. re, uti sequentes antea in sola America boreali visæ, nunc etiam in extrema ora Siberiæ." Amcenitates Academica, ii. 310 . 
In botanical arrangements, the Coptis will follow the Hellebores, from which it was taken, remaining in the class and order Polyandria, Polygynia, with the Multisiliquæe of Linnæus and the Ranunculacer of Jussieu. $t$ ray

The roots of this plant, from which the name of goldthread is taken, are perennial and creeping. On removing the moss and decayed leaves from the surface of the ground, they discover themselves of a bright yellow colour, running in every direction. The bases of the new stems are invested with a number of yellowish, ovate, acuminate stipules. Leaves ternate, on long slender petioles; leafets roundish, acute at base, lobed and crenate, the crenatures acuminate; smooth, firm, veiny. Scape slender, round, bearing one small, starry white flower, and a minute, ovate, acute bracte at some distance below. Calyx none. Petals five, six or seven, oblong, concave, white. Nectaries five or six, inversely conical, hollow, yellow at the mouth. Stamens numerous, white, with capillary filaments and roundish anthers. Germs from five to seven, stipitate, oblong, compressed; styles recurved. Capsules pedicelled, umbelled, oblong, compressed, beaked, with numerous black oval seeds attached to the inner side.

The root of this plant is a pure intense bitter, 
scarcely modified by any other taste. In distillation it communicates no decided sensible quality to water. The constituent with which it most abounds is a bitter extractive matter, soluble both in water and alcohol. It seems destitute of resinous or gummy portions, since the residuum from an evaporated solution in alcohol is readily dissolved in water, and vice versa. It is devoid of astringency when chewed in the mouth, and it gives no indication of the presence of tannin or gallic acid when tested with animal gelatin, or with sulphate of iron. The abundance of the bitter principle is evinced by the acetate of lead and nitrate of silver, both of which throw down a copious precipitate. The sulphurie, nitric, and muriatic acids occasion no change, and the muriate of tin gives only a slight precipitate, after some time standing.

of this article larger quantities are sold in the druggists' shops in Boston, than of almost any indigenous production. The demand for it arises from its supposed efficacy as a local application in aphthous, and other ulcerations of the mouth. Its reputation however in these cases is wholly unmerited, since it possesses no astringent or stimulating quality, by which it can act on the ulcerated spots, and where benefit has attended its use, it is doubtless to be ascribed to other articles 
possessing the above properties, with which it is usually combined.

As a pure tonic bitter, capable of strengthening the viscera and promoting digestion, it is entitled to rank with most articles of that kind now in use. Its character resembles that of Gentian, Quassia, and Columbo, being a simple bitter without aroma or astringency. The tincture, made by digesting half an ounce of the bruised root in eight ounces of diluted alcohol, forms a preparation of a fine yellow colour, possessing the whole bitterness of the plant. I have given it in various instances to dyspeptics and convalescents, who have generally expressed satisfaction from its effects, at least, as frequently as from other medicines of its class. A teaspoonful may be taken three times a day. In substance, it rests well on the stomach in doses of ten or twenty grains. It is however difficult to reduce to powder on account of the tenacity of its fibres.

\section{BOTANICAL REFERENCES.}

Coptis trifolia Salisbert, Lin. Trans. viii. 305.-Pursh, ii. 390.-Helleborus trifolius, $s p$. $p l$. -Wrund. ii. 1338. K ALM, Travels, iii. 379.-LEPECH. iter i. 190.-PALLAs, Iter. iii. 34.Oeder, F. Dan. t. 566.-Michaux, Fl. i. 325.-Amoen. Acad. ii. $356, t .4 . f .18$. 


\section{MEDICAL REFERENCES.}

Helleborus trifolius, Bart. Coll. Nigella.-Cutcer, Amer. Acad. i. 457.-Thacher, Disp. 283.

\section{PLATE V.}

Fig. 1. Coptis trifolia with the root, leaves, flowers and last year's fruit.

Fig. 2. Nectaries, stamens, and pistils magnified.

Fig. S. Section of a capsule shewing the seeds. 


\title{
ARBUTUS UVA URST.
}

\author{
Bear berry.$$
=
$$ \\ PLATE VI.
}

Fw $_{\text {Ew }}$ shrubs are more extensively diffused throughout the northern hemisphere, both in the old and new continents, than this trailing evergreen. We are told that it abounds in the northern parts of Europe, in Sweden, Lapland, and Iceland, and extends southerly to the shores of the Mediterranean. In Siberia it is also found, and is represented as abundant on the banks of the Wolga. In North America it grows from Hudson's bay as far south, at least, as the central parts of the United States. It occupies the most barren places, such as gravelly hills and dry, sandy woods, and covers the ground with beds of considerable extent. 


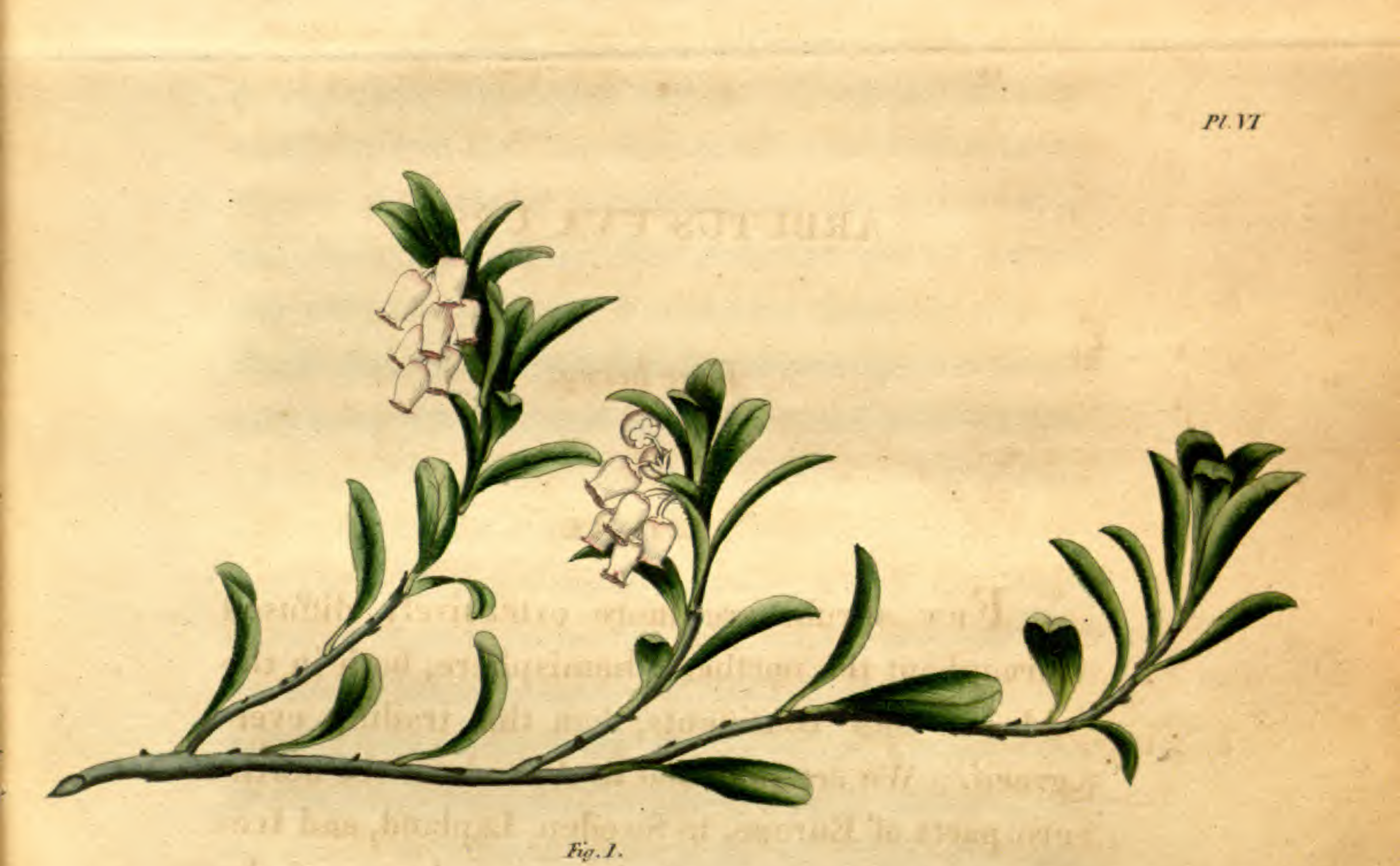


The family of plants bearing the name of Arbutus have for their distinctive marks a five-parted calyx, an ovate corolla, pellucid at base; and a superior, five-celled berry. They are closely connected to the Vaccinia or whortleberries, from which they differ principally in the situation of the berry, which in the Arbutus grows above the calyx, and in the Vaccinium below it.-Both these genera, at least the American species, properly belong to the class Decandria and order Monogynia. The Linnæan natural order is Bicornes. Jussieu has them among his Erica. Ezieducar. Gray,

The species Uva ursi, Bear's grape or Bearberry is known from the rest by its procumbent stem and entire leaves.-It trails upon the ground, putting out roots from the principal stems, and tending upward with the young shoots only. The cuticle is deciduous, and peels off from the old stems. Leaves scattered, obovate, acute at base, attached by short petioles, coriaceous, evergreen, glabrous, shining above, paler beneath, entire, the margin rounded, but scarcely reflexed, and in the young ones pubescent. Flowers in a short cluster on the ends of the branches. Peduncles reflexed, furnished at base with a short acute bracte underneath, and two minute ones at the sides. Calyx of five roundish segments, of a reddish colour and 
persistent. Corolla ovate or urceolate, white with a reddish tinge, transparent at base, contracted. at the mouth, hairy inside, with five short, reflexed segments. Stamens inserted at the base of the corolla with hairy filaments, and anthers with two horns and two pores in each. Germ round, style straight, longer than the stamens, stigma simple. Nectary a black indented ring; situated below the germ, and remaining till the fruit is ripe. Berries globular, depressed, of a deep red, approaching scarlet, containing an insipid, mealy pulp, and about five seeds, which in the American plant cohere strongly together, so as to appear like the nueleus of a drupe.

The leaves and stems of the Uva ursi are used in Sweden and Russia for the purpose of tanning leather. According to Linnæus, large quantities are annually collected for this use.

When chewed in the mouth, the leaves have an astringent taste, combined with some degree of bitterness. The result of such chemical trials as I have made with them, shews that they abound in tannin, which is probably their chief active constituent. A solution of gelatin occasions a copions precipitate ; sulphate of iron an equally copious one of a black colour. Nitrate of mercury and lime water gave large precipitates from the 
decoction, the first of a light green, the last of a brownish colour. Of the existence of gallic acid, at least as it exists in galls, I have found no sufficient proof. The decoction does not redden vegetable blues, and the black precipitate with the sulphate of iron soon subsides, leaving the fluid nearly colourless. The quantity of resin, mucous matter and extractive, provided they exist in this plant, must be minute ; since the decoction was not rendered turbid by the addition of alcohol or ether, nor the tincture by the addition of water, although after standing twenty four hours, some slight flocculi appeared. Muriate of tin produced no precipitation from the decoction, though it gave one from the tincture. Acetite of lead and nitrate of silver gave large precipitates. Water distilled from this plant, suffered no change with sulphate of iron, or muriate of tin.

Professor Murray of Gottingen, finding a greater amount of soluble matter taken up by water than by alcohol, considers the former as the best menstruum for this article. A similar inference from the American plant was made by Dr. John S. Mitchell in an inaugural dissertation, published at Philadelphia in 1803. For medical uses, Murray prefers the decoction to the infusion. 
The Uva ursi was probably known to the ancients, as it grows in all the southern parts of Europe. Clusius thinks it was the ąrrov $\sigma \tau \alpha \varphi v \lambda_{\eta}$ of Galen, celebrated by him as a remedy in hemoptysis, and described as follows. "Uva ursi in Ponto nascitur, planta humilis et fruticosa, folio Memæcyli, fructum ferens rubrum, rotundum, gustu austerum." But it is well known that the brief and imperfect descriptions of the ancients were productive of little else than uncertainty in Botany.

In modern times the Uva ursi was brought into notice about the middle of the eighteenth century by De Haen, as an efficient remedy in nephritic and even in calculous cases. It had been previously in use for these complaints in Spain, at Naples and Montpellier, and as a general astringent, at a still earlier period. Its reputation was still further augmented by subsequent dissertations, published upon its properties, and different sets of experiments were instituted to ascertain if it were not actually capable of dissolving the stone of the bladder. The results most in favour of its solvent power were those of Girardi, who diminished the weight and consistency of urinary calculi, by digesting them in a preparation of this plant. It appears however that the prep- 
aration, which he employed, was an acid liquor, obtained by a destruetive distillation of the leaves, and probably not superior to other weak acids in its solvent powers. On the other hand, Professor Murray found what might reasonably be expected, that these calculi were not materially affected by long digestion in a decoction of this plant at various temperatures.

The attention of many medical writers has been called to the properties of this medicine, and their reports as to its success are extremely various. Among its greatest friends, are De Haen, Professor Murray, and Dr. Ferriar; while of those whose opinion is more unfavouraple, are Sauvages, Haller, Donald, Munro and Fothergill. Dr. Cullen adopts the opinion of De Heucher, that the symptoms of calculus generally are susceptible of relief from astringents, and believes that on this principle the Uva ursi is capable of mitigating complaints arising from that source.*

In this country the Uva ursi has acquired the good opinion of practitioners of medicine in re-

* In the preface to the third volume of Medical Observations and Inquiries, published at London, it is stated in very general terms, that the Uva ursi had been prescribed unsuccessfully by many of the members of the Society of Physicians in London. Dr. Woodville, in his Medical Botany, has unfortunately misquoted this passage, by reading " successfully" instead of " unsuccessfully." 
peated instances. Professor Wistar of Philadelphia, as eited by Dr. Mitehell, has in several cases found symptoms like those of urinary calculus completely removed by this medicine. But these could not probably have been cases of real calculus. The late Professor Barton found the plant of much service in his own case of nephritic paroxysms, alternating with gout in the feet.

From the various testimonies which have been given respecting the properties of this article, wo are not warranted in believing it to possess any real lithontriptic power. At the same time it undoubtedly proves a palliative for calculous symptoms in many cases.

I have repeatedly watehed its effects in paroxysms of nephritis, brought on by gravelly concretions, and am on the whole inclined to believe in its tendency to allay sensibility in these cases, and to hasten the relief of the symptoms. It ought generally to be preceded by evacuations, and may be advantageously accompanied with opium.-In cases of dysury arising from a variety of causes, I have given the decoction of this plant with very satisfactory success in repeated instances.

The other diseases in which this plant has been recommended are, catarrhus vesicæ, leucorrhæa 
and gonorrhæa. All these complaints it has doubtless cured, but is at the same time inferior to other medicines in use for the same purposes.

Some years ago the Uva ursi was recommended as a remedy in pulmonary consumption by Dr. Bourne of Oxford in England, and by other writers in the periodical works. It was stated to have a very sensible effect in diminishing hectic fever, and abating the frequency of the pulse dependent on it. We do not find however that subsequent experience has justified the expectations formed of it in this disease.

In Dr. Mitchell's experiments on the pulse with this medicine, it appears that the pulsations were sometimes, not always, slightly increased after taking it, but that in every case they soon sunk below the natural standard, and remained so for some time.

of the powder of the leaves of Uva ursi, from one to two scruples may be given to most patients. Dr. Ferriar's dose in nephritis was from five to ten grains, but a larger quantity is more effectual, and is readily borne by the stomach. The decoction may be made from half an ounce of the leaves boiled for ten minutes in a pint of water. From a wine glass to a gill of this may be taken every hour. 


\section{BOTANICAL REFERENCES.}

Arbutus Uva ursi, Linneus, $\boldsymbol{F l}$. Lapponica, 162, $t$. vi. $f$. S.Oeder, Fl. Dan. t. 33.-Woodville, i. t. 70.-Sмith, Fl. Brit. 443.-Engl. Bot. t. 714.-Michadx, $F l$. i. 249.-PURSh, i. 282. -Uva ursi, J. BaUhin, i. 523.-Ceusivs, Hispan. 79.-LoBeL, Icon. i. 366.-PARKinson, theatr. 1457.-Vitis Idæa, RAIUs, Hist. 1489.

\section{MEDICAL REFERENCES.}

Murrax, Apparatus Med. ii. 64.-Girardi, de Uva ursina, \&c.-De Haen, Ratio medendi, ii. 160, \&c.-SAUvages, Nosol. iii. 2, 200.-D. Munro, Mat. Med. iii. 288.-Fothergitu, .Med. Obs. 144.-Alexander, Exp. essays, 151.-Ferriar i. 109.Heberden 79, 360.-Davie, Med. and Phys. Journal, xv. 347.Bodrne, in ditto, xiv. 463.-SchoRP, 67.-MitcheLt, Inaingural Thesis.

\section{Plate Vi.}

Fig. 1. Arbutus Uva ursi, the American variety.

Fig. 2. The magnified corolla opened, shewing the insertion of the stamens.

Fig. 3. Calyx, nectary, germ, and style magnified.

Fig. 4. Calyx and nectary.

Fig. 5. Berry. 


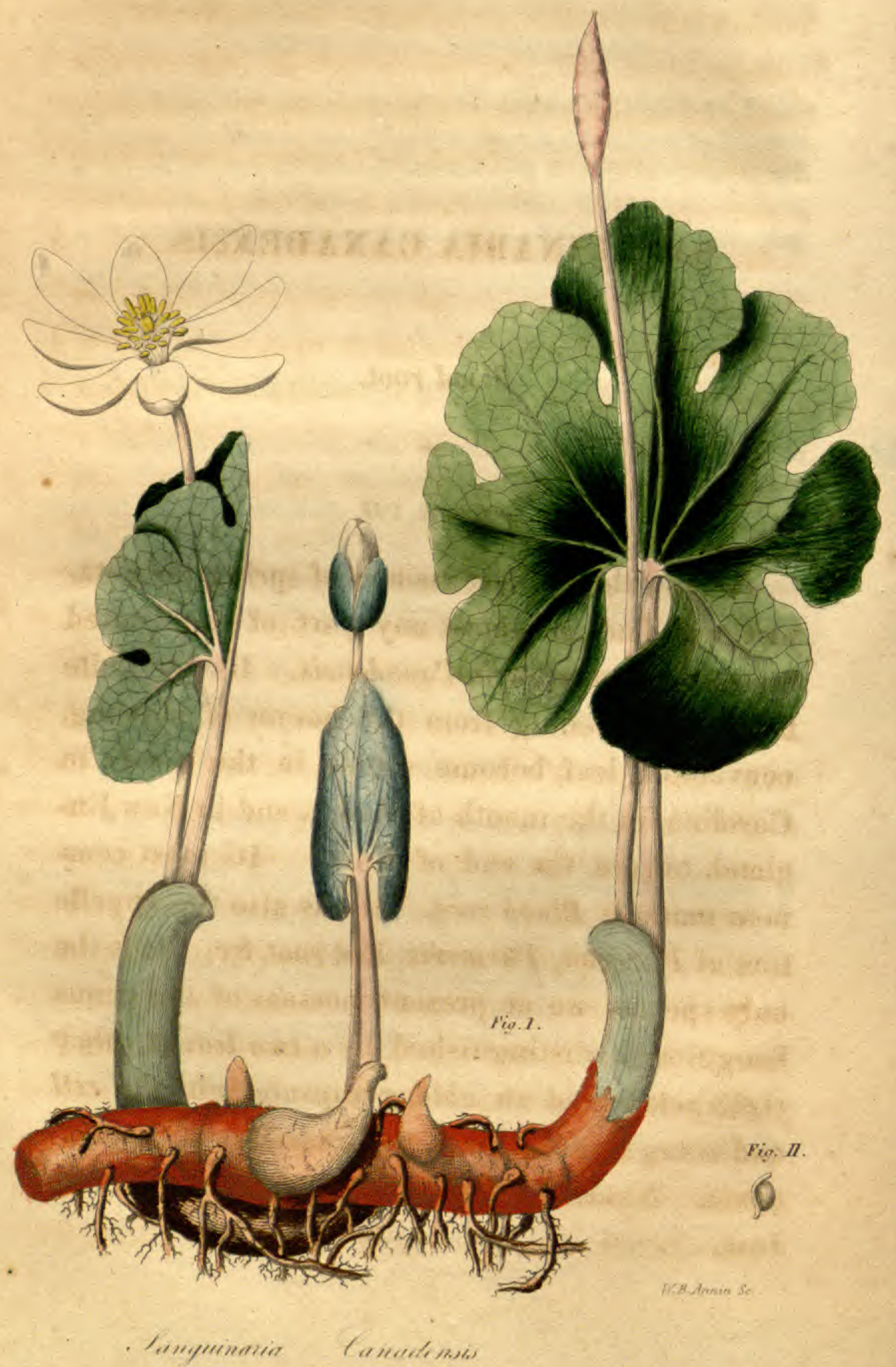




\section{SANGUINARIA CANADENSIS.}

\section{Blood root. \\ PLATE VII.}

Among the earliest visiters of spring the botanist will find in almost any part of the United States the Sanguinaria Canadensis. Its fine white flowers proceeding from the bosom of a young, convoluted leaf, become visible in the woods, in Carolina, in the month of March, and in New England, toward the end of April. Its most common name is Blood root. It has also the appella tion of Puccoon, Turmeric, Red root, \&c. It is the only species we at present possess of the genus Sanguinaria, distinguished by a two leaved calyx eight petals, and an oblong capsule, with one cell and many seeds. - Class Polyandria, order Monogynia. Natural order Rhoeadec, L. Papaveracea, Juss. 
The flower and leaf proceed from the end of a horizontal, fleshy, abrupt root, fed by numerous radicles. This root makes offsets from its sides, which separate as the old root decays, acquiring by this separation the abrupt or premorse form.

Externally the colour of the root is a brownish red. Internally it is pale, and when divided emits a bright orange coloured juice from numerous points of its surface. The bud or hybernaculum, which terminates the root, is composed of successive scales or sheaths, the last of which acquires a considerable size, as the plant springs up. By dissecting this hybernaculum in the summer or autumn, we may discover the embryo leaf and flower of the succeeding spring, and with a common magnifier, even the stamens may be counted.

The Sanguinaria is smooth throughout. The leaves grow on long channelled petioles. When spread out, they are reniform or heart shaped, with large roundish lobes separated by obtuse sinuses. The under side is strongly reticulated with veins; it is paler than the upper, and at length becomes glaucous. The scape is round, rises in front of the petiole, and is infolded by the young leaf. The calyx consists of two concave, ovate, obtuse leaves, which are perfect in the bud, but fall off when the corolla expands. Petals eight, 
spreading, concave, obtuse, the alternate or external ones longer, so that the flower has a square appearance. This is its natural character, although cultivation sometimes increases the number of petals. Stamens numerous, with oblong yellow anthers. Germ oblong, compressed, style none, stigma thick, somewhat two lobed. Capsule oblong, acute at both extremities, two valved. Seeds numerous, roundish, compressed, dark shining red, half surrounded with a peculiar white vermiform appendage, which projects at the lower end.

After the flower has fallen, the leaves continue to grow, and by midsummer have acquired so large a size as to appear like a different plant.

The root of this vegetable is the only part which I have submitted to chemical examination. The experiments made on this substance, gave evidence of the following constituent principles.

1. A peculiar resin. Alcohol comes off from the root strongly impregnated with its colour and taste. This solution is rendered turbid by the addition of water. When evaporated to dryness, it leaves a residuum partially, but not wholly soluble in water. When successive quantities of water have been agitated with the powdered root until the infusion comes off colourless, alcohol acquires 
a colour from the remainder. $Z$ Ether receives from the root a yellowish colour, and when evaporated, leaves the resin nearly pure. In this state it is moderately adhesive, of a deep orange colour, bitter and acrid, diffusible, but not soluble in water. The resin may also be precipitated in small quantities from alcohol by water.

2. A bitter principle. Both water and alcohol acquire a strong bitter taste when digested on the root. From both these solutions a copious precipitate is thrown down by the nitrate of silver and the acetite of lead. Muriate of tin gradually renders the solution turbid, but without a precipitate. Oxymuriatic acid renders the alcoholic solution turbid, but produces no change in the watery solution for some time. At length a precipitate forms and slowly subsides; but produces no change in the watery solution. No precipitate was formed from the cold aqueous infusion in an hour by the sulphuric or nitric acids, by lime water, nitrate of mercury, muriate of barytes, oxalate of ammonia, sulphate of iron, gelatine or bydro-sulphuret of potash. After standing twenty four hours, a very slight precipitate was discovered from the lime water and nitrate of mercury only.

3. An acrid principle. The acrimony resides in part in the resin, but is also communicated to 
water. It is diminished by heat, yet it does not come over with water in distillation.

4. Frecula. The infusion of the root in cold water is limpid. The hot infusion is viseid and glutinous and stiffens linen. From this solution the frecula is precipitated in a white powder by alcohol. Nitric acid dissolves this precipitate, which may be again thrown down by alcohol.

\section{A fibrous or woody portion.}

The beautiful colour of the root seems to reside more in the resin than in any other principle, since the alcoholic solution has always more than twice as much colour as the aqueous. Papers dipt in these solutions receive a bright salmon colour from the tincture, but a very faint one from the aqueous infusion. This cireumstance furnishes an impediment to the use of this article in dyeing.

The medical properties of the Sanguinaria are those of an acrid narcotic. When taken in a large dose it irritates the fauces, leaving an impression in the throat for considerable time after it is swallowed. It oceasions heartburn, nausea, faintness, and frequently vertigo and diminished vision. At length it vomits, but in operation it is less certain than other emetic in common use. The above effects are produced by a dose of from eight to twenty grains of the fresh powdered root. 
When given in smaller doses, such as produce nausea without vomiting, and repeated at frequent intervals, it lessens the frequency of the pulse in a manner somewhat analogous to the operation of Digitalis. This however is a secondary effect, since in its primary operation it seems to accelerate the circulation. Exhibited in this manner, it has been found useful in several diseases.

In still smaller doses, or such as do not excite nausea, it has acquired some reputation as a tonic stimulant.

Professor Smith of Hanover, New Hampshire, in a paper on this plant, published in the London Medical Transactions, vol. i. states that he found the powder to operate violently as an emetic, producing great prostration of strength, during its operation, which continued for some time. He had not known it to act as a cathartic. Snuffed up the nostrils, it proved sternutatory, and left a sensation of heat for some time. Applied to fungous flesh it proved escharotic, and several polypi of the soft kind were cured by it in his hands. He found it of great use in the incipient stages of pulmonary consumption, given in as large doses as the stomach would bear, and repeated. In cases of great irritation it was combined with opium. Some 
other complaints were benefitted by it, such as acute rheumatism and jaundice.

Professor Ives of New Haven* considers the Blood root as a remedy of importance in many diseases, particularly of the lungs and liver. He observes, that in typhoid pneumonia, "in plethoric constitutions, when respiration is very difficult, the cheeks and hands become livid, the pulse full soft, vibrating and easily compressed,-the Blood root has done more to obviate the symptoms and remove the disease," than any remedy which he has used. In such cases, he observes, " the dose must be large in proportion to the violence of the disease, and often repeated, until it excites vomiting, or relieves the symptoms." He infuses from a scruple to half a drachm of the powdered root in half a gill of hot water, and gives one or two teaspoonfuls every half hour, in urgent cases, until the effect is produced. This treatment has often removed the symptoms in a few hours.

Dr. Ives thinks highly of its use in influenza, in phthisis, and particularly in hooping cough, He also states, that given in large doses, sufficient to produce full vomiting, it often removes the Croup, if administered in the first stages. It has been given, he remarks, "for many years in the

* Letter dated November 5, 1816. 
country, some physicians relying wholly on this remedy for the cure of croup."

Dr. Macbride, of Charleston, S. C. who has contributed many judicious remarks on the medicinal properties of plants, to Mr. Elliott's excellent Botany of the Southern States ; informs me,* that he has found the Blood root useful in $\mathbf{H y}$ drothorax, given in doses of sixty drops, ter de die, and increased until nausea followed each dose. In a week or two the good effect was evident, the pulse being rendered slow and regular, and the respiration much improved. In the same letter he observes, "In torpor of the liver, attended with colic and yellowness of the skin, a disease common in this climate, I use the Puccoon with evident advantage. We use it also in jaundice, but in this disease I do not trust exclusively to it. I prefer the pill or powder (dose from two to five grains) and vinous infusion, to the spirituous tincture."

The tincture of Sanguinaria may be made by digesting an ounce of the powdered root in eight ounces of diluted alcohol. This preparation possesses all the bitterness, but less of the nauseating quality, than the infusion. In the dose of a small teaspoonful, it is used by many practitioners

* Letter dated December, 1816. 
as a stimulating tonic, capable of increasing the appetite and promoting digestion.

\section{BOTANICAL REFERENCES.}

Sanguinaria Canadensis, Liv. sp. pl.-Curtis, Botan. Mag. t. 162.-Aiton, Hort. Kew. ii. 222.-W ALter, Carol. 153.Michaux, Flora 1, 309.-Pursh, ii. 366.-Sanguinaria minor, Dulenivs, Elth. $f .326$ and S. major, $f .325$ in $t$. 252.-Chelidonium maximum acaulon Canadense RArvs, Hist. 1887.-Ranunculus Virg. albus. Parkinson, Th. 326.-Chelidonium majus Canad. acaulon Corvotus, Canad. 212.

MEDICAL REFERENCES.

Scherp, 85.-Sмiтh, Trans. Lond. Med. Society, i. 179.Bart. Coll. 28.-Cutler, Mem. Amer. Acad. i. 455.-Thacher, Disp. 331. 


\title{
GERANIUM MACULATUM.
}

\author{
Common Cranesbill.
}

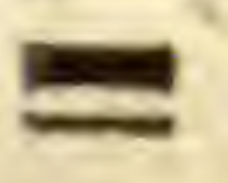

\section{PLATE VIII.}

In common language the term Geranium includes all that extensive tribe of plants comprised by the old genus of that name, and principally characterised by their beaked fruit and five seeds which are scattered by means of awns. L'Heritier has divided this family into three distinct genera, under different orders in the artificial class Monadelphia. 'These are Erodium, having five stamens, five nectariferous scales and glands, and the awns of the fruit twisted and bearded. Pelargonium, which includes most of the Cape species so commonly cultivated among us, having about seven stamens, an irregular corolla, and a nectareous tube running down the peduncle. Lastly, Geranium having ten stamens, a regular corolla, five nec- 


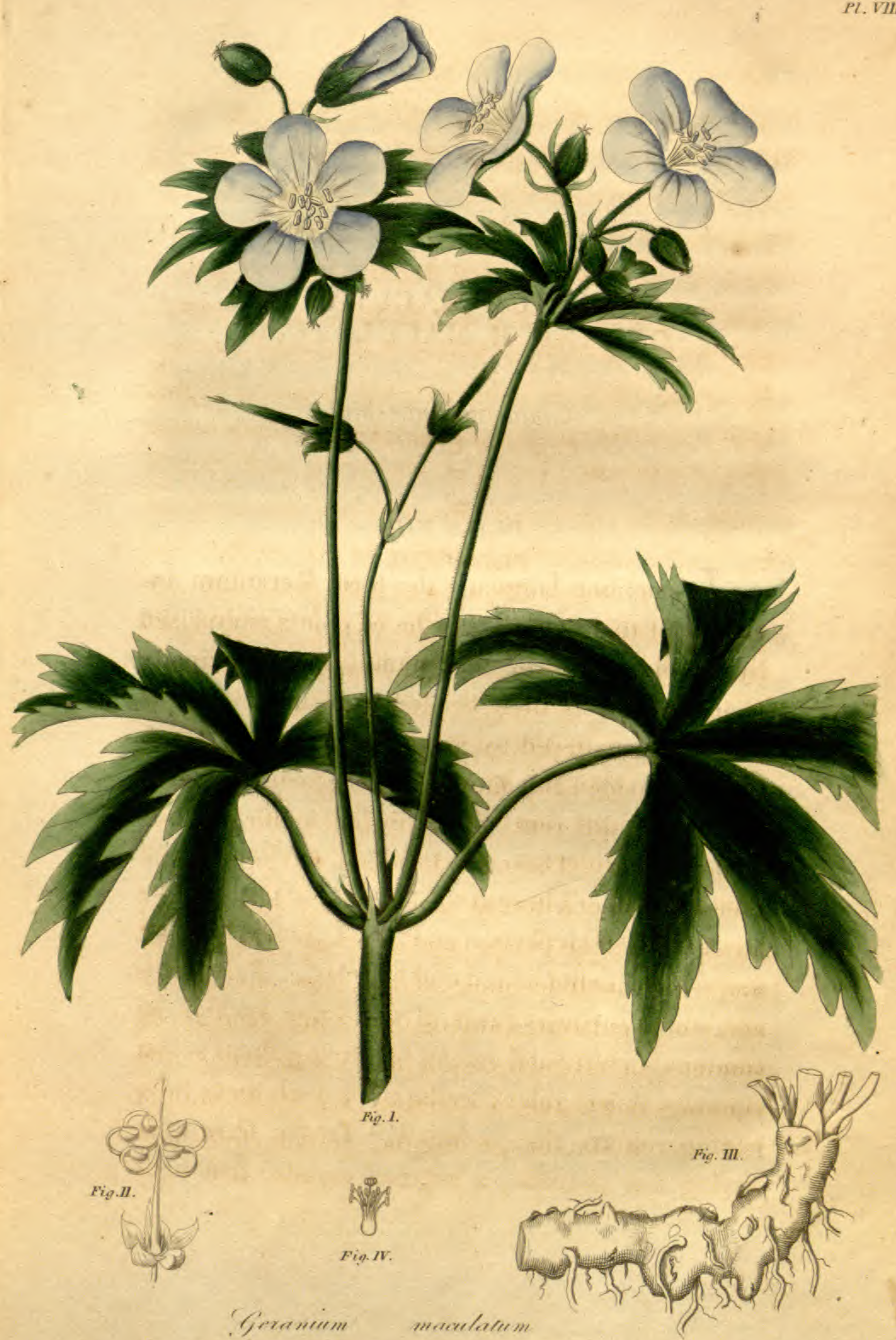


tariferous glands at the base of the longer filaments, the awns of the fruit neither bearded nor twisted. To this division belongs the plant under consideration, which has the following specific character. Erect, hairy backward; stem forked; leaves opposite, three or five parted, cut; peduncles mostly two flowered; petals, obovate, entire.

Jussieu has formed a natural order by the name of Gerania, which nearly corresponds to the Gruinales of Linnæus.

Although we have few species of Geranium in the United States, yet the present species, by its extensive diffusion, is a sufficient representative of the race. It is very common in low grounds, about Boston and Philadelphia, in the Carolinas, and in the western country upon the banks of the Ohio and Illinois.

The root of Geranium maculatum is perennial, horizontal, thick, rough and knobby. In most plants it sends up a stem and several root leaves. The leaves are spreading, hairy, divided in a palmate manner into three, five, or seven lobes, which are variously cut and toothed at their extremities; those of the root are on long petioles, those at the middle of the stem opposite and petioled, those at the top opposite and nearly sessile. The stem is erect, round, hispid with reversed hairs, 
dichotomous, with a flower stalk in the fork. Stipules and bractes linear, dilated at base. Peduncles round, hairy, swelling at base, generally two flowered. Calyx of five oblong, ribbed, mucronated leaves, with the parts, which are outermost in the bud, hairy. Petals five, obovate, not emarginate, of a light purple colour, which is deeper when the plant grows in the shade, marked with green at the base. Stamens ten, erect or curving outward, the alternate ones a little longer, with nectariferous glands at the base ; filaments dilated and united together at base; anthers oblong, deciduous, so that the number frequently appears less than ten. Germ ovate; style straight, as long as the stamens ; stigmas five, at first erect, afterwards recurved. Capsule five seeded, surmounted by a long straight beak, from the sides of which when ripe are separated five thin, flat awns, which curl up, having cast off the seed contained in the cell at the base of each.

The root of the Geranium, which is the part to be used in medicine, is internally of a green colour, and when dry is exceedingly brittle and easily reduced to powder. It is one of the most powerful astringents we possess, and from its decided properties, as well as the ease of procuring it, it may well supersede in medicine many foreign ar- 
ticles of its class which are consumed among us. The experiments, which I have made upon this root, have been principally directed to the examination of its astringent qualities.

A drachm of the powdered root was steeped in two ounces of cold water and the infusion filtrated. Successive portions of water were added until the liquid came off colourless and tasteless. The collected infusion had a pale greenish colour, and a styptic, austere taste. It did not redden vegetable blues.

To half this infusion was added a drachm of gelatin in solution. The liquor instantly became of a milky whiteness, and a copious white precipitate was thrown down. This precipitate was dried and assumed a semi-transparent, horny appearance. Its weight was eleven grains.

A drachm of kino treated in the same manner was rendered turbid, but gave a very scanty precipitate with the gelatin.

To portions of the same infusions was added a solution of the muriate of tin. In both of them a greenish precipitate was formed, but that of the Geranium was much the most immediate and abundant.

The sulphate of iron struck a dark purple colour with the infusion of Geranium. The com- 
pound remained principally suspended at the end of twenty four hours, and when used in writing had the appearance of common ink, but in a few days changed to a dull brown colour. A portion of the fresh infusion was distilled, but the liquid which came over was not altered in colour by the sulphate of iron.

The above experiments indicate the presence of tannin and gallic acid, the former in large quantities, in the root of the Geranium. The proportion of tannin seems considerably to exceed that in the kino of the shops. The gallic acid is indicated by the dark precipitate remaining in solution. This is Berthollet's criterion. It differs however from the acid of oak galls in not reddening vegetable blues, and not passing over in distillation.

Alcohol and proof spirit readily dissolve the active constituents of the Geranium. The tincture has a great sensible astringency, and is a convenient mode of keeping the article for use.

The Geranium has been repeatedly employed in medicine by various practitioners in this country. I have found it useful in a number of cases, where astringents were capable of rendering service. It is particularly suited to the treatment of such discharges as continue from debility after the removal of their exciting causes. The tinc- 
ture forms an excellent local application in sore throats and ulcerations of the mouth.

Its internal use has been recommended in dysentery and cholera infantum, but astringents are not always admissible in these complaints, at least in their early stages, during the existence of much active inflammation, or during the presence of any substance requiring to be removed.

The Geranium may be used in powder in extract, or in tincture. Its doses are similar to those of kino and catechu, a drachm or two of the tincture, twenty or thirty grains of the powder, and a quantity somewhat less of the extract.

\section{BOTANICAL REFERENCES.}

Geranium maculatum, $S p \cdot p l$. Wrudenow, iii. 705.-Grovovius, Virg. 101.-Watter, Carol. 175.- Мrсhaux, ii. 38.Pursh, ii. 448.-G. caule erecto, herbaceo, foliis oppositis, quinque partitis, incisis \&c. Cavanitess, diss, $t .86, f .2 .-\mathrm{G}$. batrachioides, Americanum, maculatum, floribus obsolete cœruleis, Diw. Elth. 158. t. 131, f. 159.

\section{MEDICAL REFERENCES.}

Schopp, 107.-Bart. Coll. 7.-Cuther, Mem. Amer. Acal. i. 469.-Thacher, Disp. 224.

\section{PLATE VIII.}

Fig. 1. Geranium maculatum.

Fig. 2. The fruit.

Fig. 3. The root. 


\title{
TRIOSTEUM PERFOLIATUM.
}

\author{
Fever root.
}

$=$

PLATE IX.

$\mathrm{T}_{\mathrm{HIS}}$ is rather a solitary plant, and though met with in most parts of the United States, it rarely, I believe, occurs in large quantities. About Boston it is found in several places at the borders of woods in rich, shady situations. Its common names are Fever root and Wild ipecac.* Pursh observes, that it is rare, and generally occurs in limestone soils. With us it flowers in June and ripens its fruit in September.

The genus Triosteum is found in the class

* The quaint appellation of Dr. Tinker's weed, which has been bestowed on this plant, is thus gravely commented on by Poiret. "Ses racines et celles de l'espece précédente passent pour émétiques; le docteur Tinkar est le premier qui les a mises en usage, et qui a fait donner à cette plante par plusieurs habitans de l'Amerique septentrionale le nom d' herbe sauvage du docteur Tinkar." 


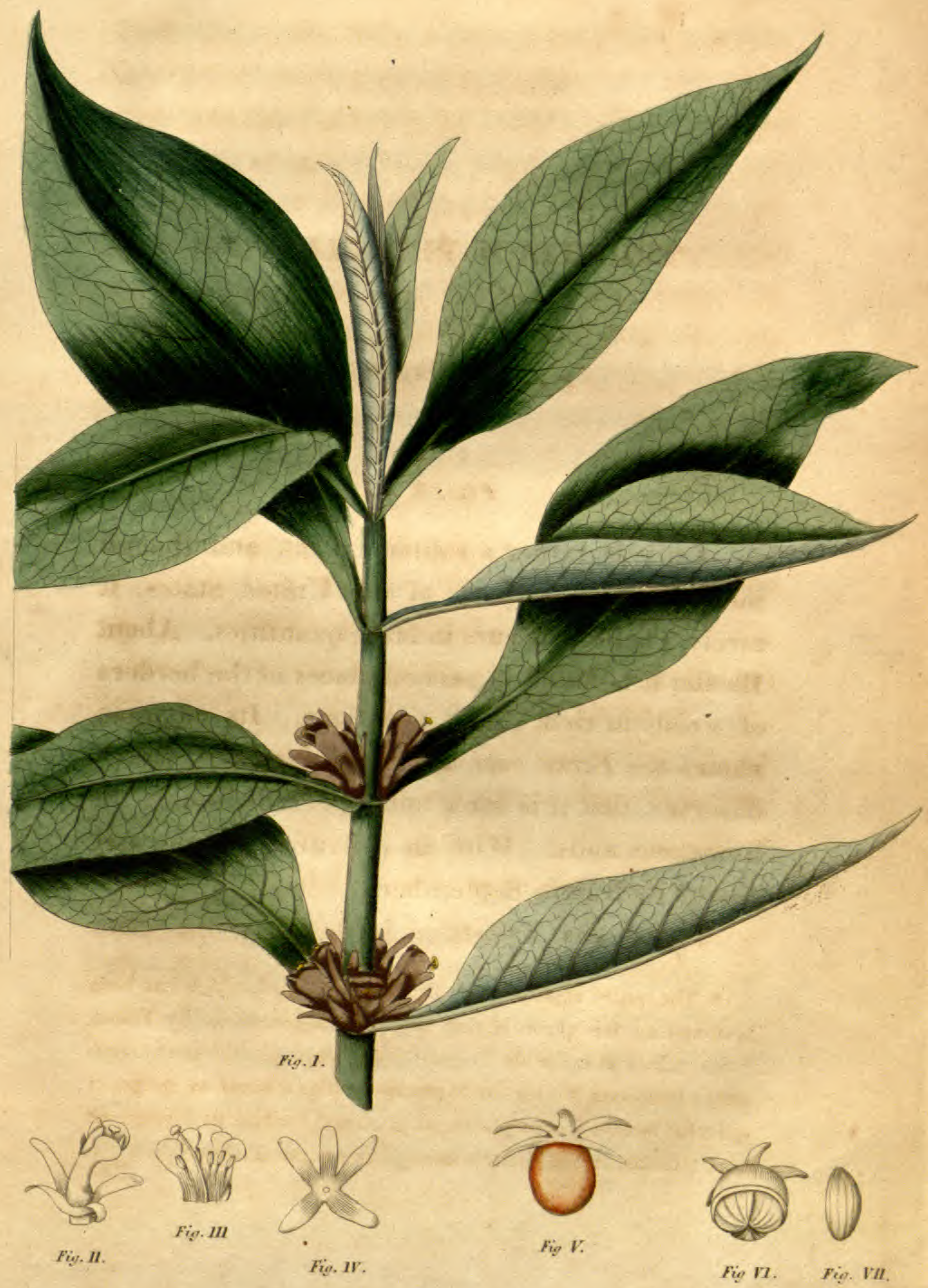


Pentandria and order Monogynia. Its natural affinities place it among the Agrregate of Linnæus and the Caprifolia of Jussieu. It is charac-Caprifoliarean if terized by a monopetalous, five-lobed, unequal corolla; a calyx as long as the corolla; and a ber$r y$ with three cells and three seeds. The species perfoliatum differs from the rest in having its leaves connate, and its flowers sessile and whorled.

The root of this plant is perennial and subdivided into numerous horizontal branches. The stem is erect, hairy, fistulous, round, from one to four feet high. The leaves are opposite, the pairs crossing each other, connate, ovate, acuminate, entire, rather flat, abruptly contracted at base into a sort of neck, resembling a winged petiole. This portion varies in width, as Michaux has expressed it, "foliis latius, angustiusve connatis." In general it is narrow when the plant is in flower, as represented in the figure; and wider when it is in fruit. The flowers are axillary, sessile, five or six in a whorl, the upper ones generally in a single pair. Each axil is furnished with two or three linear bractes. The calyx consists of five segments which are spreading, oblong-linear coloured, unequal, persistent. Corolla tubular, curving, of a dull brownish purple, covered with minute hairs, its base gibbous, its border open and 
divided into five rounded, unequal lobes. Stamens inserted in the tube of the corolla, hairy, with oblong anthers. Germ inferior, roundish; style longer than the corolla; stigma peltate. The fruit is an oval berry of a deep orange yellow, * hairy, somewhat three sided, crowned with the calyx, containing three cells and three hard, bony, furrowed seeds, from which the name of the genus is taken.

This plant was made the subject of an interesting communication to the Linnæan society of New England, by Dr. John Randall. The experiments made by him on its medical uses and pharmaceutical preparations were numerous, and serve to throw much light on its properties. In trying the solvent powers of water and alcohol, he found that water afforded a much greater quantity of extract than alcohol, and that the spirituous extract was perfectly soluble in water, whence he infers that no resin in a pure state exists in the plant. He discovered no volatile oil by distillation, nor any other principle of activity in water distilled from the plant. He concludes also, that

* Pursh observes that the flowers and berries are purple. In all the specimens I have examined, which have not been few in number, the fruit was of a bright orange colour. If Pursh has seen a plant with purple berries, it is probably a different species from the true plant of Linnæus and Dillenius, which had "fructus lutescentes." 
no free acid exists in this vegetable. Of the different parts submitted to examination, the leaves yielded the greatest quantity of soluble matter, but the root afforded that of the greatest activity. By decoction and evaporation with water an ounce of the dried stalks afforded one drachm of extract; an ounce of the dry roots, two drachms and two scruples, and the same quantity of leaves half an ounce. From a similar treatment of equal portions with alcohol, rather more than half the above quantities of extract were obtained.

The sensible qualities of the root were found essentially different from those of the herb. Both of them possess a large share of bitterness, but the root has also a nauseous taste and smell, somewhat approaching to those of ipecacuanha. The medical properties of the Triosteum are those of an emetic and cathartic. In the above dissertation, about thirty cases are detailed, in which different preparations and quantities of the article were given to various persons with a view to their medicinal effects. The general inference to be made from them 1s, that the bark of the root acts with tolerable certainty as an evacuant upon the alimentary canal, both by emesis and catharsis. When given alone, either in powder or decoction, the instances of its failure were not many, and 
when combined with calomel, its operation was attended with a certainty, hardly inferior to that of jalap. The aqueous and spirituous extract of the root were likewise efficacious, and nearly in an equal degree. Preparations made from different parts of the herb possessed much less activity, the decoction of the leaves operating only as a diaphoretic, and that of the stalk producing no effect.

The late Professor Barton of Philadelphia, in his Collections toward a Materia Medica of the United States, speaks of this plant as a mild and good cathartic, sometimes operating as a diuretic and in large doses as an emetic.

My own experience with this plant has not been extensive, yet sufficient to satisfy me of its medicinal power. Where I have administered it, it has generally proved cathartic, a larger dose however being requisite for this purpose, than of jalap or aloes. It has sometimes failed to produce any effect, and I am inclined to believe that its efficacy is much impaired by age. Those who may incline to employ it, will do well to renew their stock annually, and to keep the powder in close stopped phials.

A dose of the bark of the root in powder is twenty or twenty five grains, and of the extract, a somewhat smaller quantity. 


\section{BOTANICAL REFERENCES.}

Triosteum perfoliatum, LIN. sp. pl. AIton, Hort. Kerw, i. 234. -Pursh. i. 162.-Triosteum majus, Mrchadx, Fl. i. 107.-T. floribus verticillatis, sessilibus, Gronov. 31.-Triosteospermum latiore folio, flore rutilo, Druenrus, Elth. $t$. 293. f. 378.

\section{MEDICAL REFERENCES.}

SCHCEPF, 23.-BART. Coll. 29.

\section{PLATE IX.}

Fig. 1. Triosteum perfoliatum.

Fig. 2. A flower separated.

Fig. 3. The corolla opened, shewing the stamens and style.

Fig. 4. The calyx.

Fig. 5. The fruit, crowned with the calyx.

Fig. 6. The same dissected to shew the three seeds.

Fig. 7. A seed. 


\section{RHUS VERNIX.}

Poison Sumach or Dogrwood. $=$

PLATE $X$.

$\mathbf{T}_{\mathrm{HE}}$ fine, smooth foliage of the Rhus vernix render it one of the most elegant of our native shrubs, while its well known poisonous qualities make it an object of aversion, and deter most persons from a near inspection of its structure and characteristics. From Canada to Carolina it is a common tenant of swamps and meadows, usually attaining the height of ten or fifteen feet, but sometimes rising into a tree of twice that altitude. The names of Poison tree, Poison rood, Poison $a s h, \& c$. are applied to it in different parts of the United States. In Massachusetts it is universally known by the name of Dogrvood. This appellation, being applied throughout the country to Cornus florida, serves to shew the fallacy of de- 


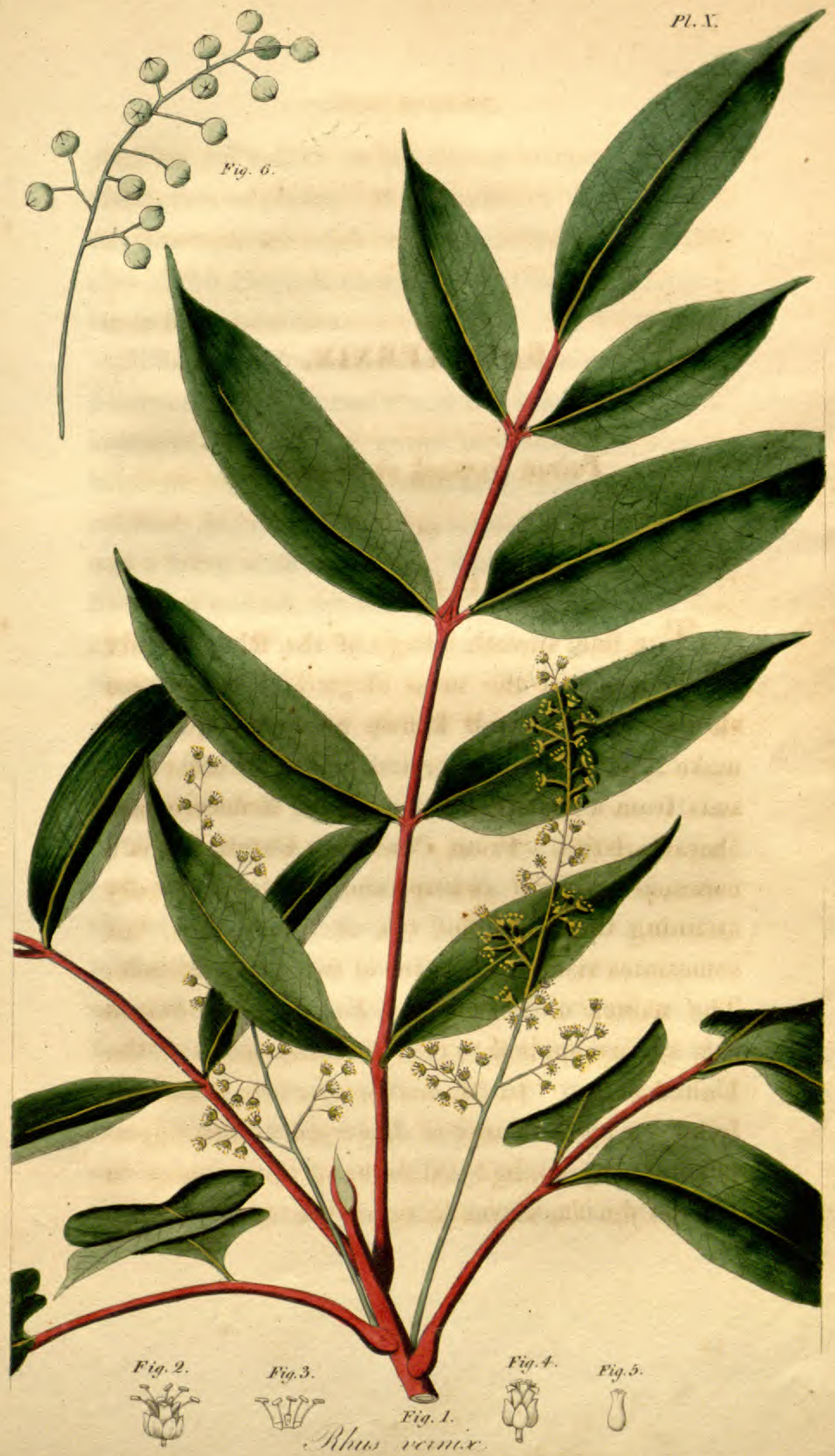


pending on vulgar or provincial names for the distinction of plants. A mistake of very injurious consequence might easily arise from the confusion of the English names of two trees so dissimilar in their qualities.

The class Pentandria and order Trigynia; the Linnean order Dumosie and the Jussieuean Terebintacere include the genus to which this shrub belongs. The generic character consists in an inferior, five-parted calyx, a corolla of five petals, and a berry with one seed. The Rhus vernix has its leaves annual, pinnate, glabrous ; its leafets oblong, entire, acuminate; its panicle lax, and its flowers diocious.

The trunk of the poison sumach is from one to five inches in diameter, branching at top, and covered with a pale greyish bark. The wood is light and brittle, and contains much pith. The ends of the young shoots and the petioles are usu. ally of a fine red colour, which contributes much to the beauty of the shrub. The leaves are pinnate, the leafets oblong or oval, entire, or sometimes slightly sinuate, acuminate, smooth, paler underneath, nearly sessile, except the terminal one. The flowers, which appear in June, are very small, green, in loose axillary panicles. Where they appear not axillary, it is because the leat un- 
der them has been detached. The barren and fertile flowers grow on different trees. The panicles of barren flowers are the largest and most branched. They are furnished with short, oblong: bractes, and downy pedicels. The calyx has five ovate seginents, and the corolla five eblong, sigmoid petals. The stamens are longer than the petals, and project through their interstices. The rudiment of a three-cleft style is found in the centre.-In the fertile flowers, the panicles of which are much smaller, the ealyx and petals resemble the last, while the centre is occupied by an oval germ, ending in three circular stigmas. The fruit is a bunch of dry berries or rather drupes of a greenish white, sometimes marked with slight purple veins, and becoming wrinkled when old. They are roundish, a little broadest at the upper end, and compressed ; containing one white, hard, furrowed seed.

A tree, supposed to be the same with the Rhus vernix, grows in Japan, and furnishes the celebrated black varnish of that country.

A controversy respecting the identity of the Japanese and American species, was carried on in the forty winth and fiftieth volumes of the London Philosophical transactions, by Mr. Philip Miller 
and Mr. John Ellis. The mass of evidence seems to justify the belief, that notwithstanding the remoteness of their situation, they are one and the same species. The description of the oriental tree, given in Kæmpfer's Amœnitates exoticæ, agrees very closely with that of the American species. [Note G.] Like our native Rhus, the Japanese tree possesses a poisonous influence, and frequently causes a severe cutaneous affection in those who approach or gather it. It only remains to shew, that a varnish may be obtained from the American Rhus vernix, to furnish strong presumptive evidence of the identity of the two.

If an incision be made in the bark of our Rhus vernix in the spring or autumn, a quantity of thick viscid fluid immediately exudes, and sometimes with such rapidity as to drop off before it can be collected. This juice has an opaque, whitish appearance, and a strong, penetrating, disagreeable smell. On exposure to the atmosphere, its colour soon changes to a deep black. It is extremely slow in drying, and permanently retains its black colour.

In the month of October, 1814, with the assistance of Dr. Pierson, whose case is afterwards described; I collected several ounces of this juice from a thicket of trees in Brighton. Being col- 
lected in a phial, it retained its whitish colour, except at the surface, where it turned black from its contact with the air in the upper part. This juice was kept for more than two years without any change in its appearance. In cold weather it was extremely viscid, and flowed with difficulty.

Different portions of this juice were submitted to chemical examination. It was perfectly insoluble in water, although upon boiling with it, it formed a thick emulsion. Alcohol dissolved it sparingly, and the solution was rendered turbid by water. Ather combined with it more largely, forming a thick, opaque compound. Strong sulphuric acid combined with it, producing a black solid mass. Alkalies also combined with it, and a strong solution of pearl ash dissolved a portion of it, which was afterwards precipitated by sulphuric acid. It had an affinity for metallic oxyds, and powdered litharge, upon being boiled with it, rendered it nearly solid. In distillation at the heat of boiling water, nothing came over except a slight film upon the surface of the water. When the heat was raised to the boiling point of the juice, a quantity of thin, blackish, volatile oil came over, which dried up on being exposed to the air, leaving a slight coating on the surface of the ressel which contained it. The 
portion remaining in the retort was much inspissated, and upon cooling became nearly solid.

Being desirous to try the effect of this juice, employed as a varnish, I applied a coating of it with a brush to different surfaces of wood, glass, tinned iron, paper, and cloth. These were exposed to the air and light during the whole of the months of July and August, at the expiration of which period they had not become dry. Each of the coatings was half fluid and adhesive, and had collected much dust. Upon the cloth and paper the juice had spread extensively, giving them an oily appearance.

Concluding from this experiment that the juice could not be usefully employed in its crude state, I endeavoured to render it more drying by the addition of litharge. The compound, which resulted from boiling with this oxyd, became dry in a short time, but was not distinguished for any remarkable degree of lustre.

The third and last experiment proved more satisfactory. A quantity of the juice was boiled alone, until nearly all the volatile oil had escaped, and the remainder was reduced almost to the state of a resin. In this state it was applied while warm to several substances, which after cooling exhibited the most brilliant, glossy, jet black sur- 
face. The coating appeared very durable and firm, and was not affected by moisture. It was elastic and perfectly opaque, and seemed calculated to answer the purposes of both paint and varnish.

The chemical constitution of the juice of the Rhus vernix seems, from the foregoing experiments, to be most analogous to that of the balsams, consisting chiefly of a resin and an essential oil. The oil dissipates slowly at low temperatures, approaching in this and some other respects to the character of a fixed oil. The resin, when procured in contact with the atmospheric air, is black, opaque, and solid, rendered very adhesive, and at length fluid by heat.

A very distressing, cutaneous disease, it is well known, ensues in many persons from the contact, and even from the effluvium of this shrub. The poisonous influence which produces this affection is common to several other trees and plants, such as the Poison vine or Poison ivy, (Rhus radicans,) the Cashew nut, (Anacardium occidentale,) and the Manchineel, (Hippomane mancinella.) Even the garden Rue, and common Oleander, are said to affect some persons in a similar manner.-The Rhus vernix is the most formidable of this tribe which is found among us, 
and occasionally produces the most severe effects. It is however extremely various in its action, upon persons of different idosyncrasies. Some cannot come within the atmosphere of the shrub, without suffering the most violent consequences. Others are but slightly affected by handling it, and some can even rub, chew, and swallow the leaves without the smallest inconvenience.

The most formidable cases in persons subject to this poison, usually commence within twenty four hours after the exposure. The interval is sometimes longer, but more frequently shorter. The symptoms are generally ushered in by a sense of itching and a tumefaction of the hands and face. The swelling gradually extends over various parts of the body, assuming an erysipelatous appearance. The inflamed parts become more elevated, acquiring a livid redness, attended with a painful burning sensation. Small vesicles now appear upon the surface, which extend and run into each other. They contain a transparent fluid, which by degrees becomes yellow, and at length assumes a purulent appearance. A discharge takes place from these vesicles or pustules, giving rise to a yellowish incrustation, which afterwards becomes brown. In the mean time an insupportable sensation of itching and burning is 
felt. The inflamed parts become excessively swollen, so that not unfrequently the eyes are elosed, and the countenance assumes a shapeless and cadaverous appearance, which has been compared to that in malignant small pox. The disease is usually at its height from the fourth to the sixth day, after which the skin and incrustations begin to separate from the diseased parts, and the symptoms gradually subside. It is not common for any scars or permanent traces of the disease to remain. Notwithstanding the violent character which it sometimes assumes, I never knew an authenticated case of its terminating fatally. It is however eapable of occasioning the most distressing symptoms. Kalm, in his travels in North America, mentions a person who, by the simple exhalation of the Rhus vernix, was swollen to such a degree, that "he was stiff as a $\log$ of wood, and could only be turned about in sheets." Dr. Thacher mentions a case, in which the head and body were swollen to a prodigious degree, so as to occasion the loss of sight for some time; and the patient recovered at the end of several weeks with the loss of his hair and nails.

Of the cases which have fallen under my notice, the following affords a fair instance of the operation of this poison, as it ordinarily effects 
those who are constitutionally liable to it. On the 27 th of October, 1814, Dr. A. L. Pierson, then a student of medicine, accompanied me to Brighton for the purpose of collecting the juice of the Rhus vernix, growing at that place. He had always supposed himself constitutionally exempt from liability to the poison. The day proved warm, and the effluvium from the incisions we had made in the trees was very powerful. We were engaged in the collection for upwards of an hour, during which he was less exposed than myself, being absent a part of the time. His own account of the symptoms which followed this exposure is as follows :

"I felt no unpleasant effects for six or seven hours after returning to Boston. About 8 o'clock P. M. I perceived the backs of my hands were swollen and puffy, but without pain or itching; my forehead and upper lip were seon in the same state. On the morning of the 28th the tumefaction had increased, and $\mathbf{I}$ discovered various other parts of my body to be infected. 'The backs of my hands and wrists, which were the most advanced, began to show small watery vesicles. No applieations were made till the noon of this day. I then applied cloths dipped in lead water to one hand and wrist, and in a spixituous solution of the 
the corrosive muriate of mercury to the other. From this and subsequent trials, I am induced to prefer the lead. The parts began to itchthe tumefaction increased-vesication began to take place on the swollen surface-small pustules formed and ran into each other, and at last some were formed as large as nutmegs. On the $29 \mathrm{th}$, my eyes were nearly closed, in consequence of the swelling of my forehead, eyebrows and cheeks. The contents of the vesicles were perfectly limpid-inoculation from them to other parts had no effect-neither in this nor any subsequent stage. On the evening of the $30 \mathrm{th}$, the inflammation appeared at its height. The burning sensation and itching were intolerable. I could scarcely discern any object. On the 31st, the pustules began to appear a little milky - and before night the inflammation was evidently on the decline. I this day applied an ointment, composed of Ung. Stramonii, 1 oz.-Subm. Hyd. c. Ammonia (white precipitate) 1 dr. mixed-with a very pleasant effect. It was now soothing, although before it had seemed to irritate, and produced pain when applied. November 1st, a very free desquamation began, first on my forehead, hands and wrists. And in just a fortnight I was enabled to leave my chamber, blessed with a new cuticle from the root 
of the hair on my forehead to my breast, from the middle of $\mathrm{my}$ forearm to the tips of my fingers, and on the whole inside of my thighs. The constitutional effects of this thorough vesication were but slight. During the first five days, my pulses were increased from ten to twenty strokes in the minute. The time of duration of the inflammatory symptoms in this case accords pretty well with the account of Prof. Barton, who states, I think, the height of it to be on the fifth day. It is worth observing, that the operation of the poison seemed to have a considerable effect in relieving me from dispeptic symptoms, with which I had been previously troubled, and also benefitted a chronic inflammation of my eyes. I am still subject to an eruption of watery pustules between my fingers, which dry up, and the cuticle peels off." Letter dated July, 1815.

Many constitutions are but slightly, or not at all, affected by the poison of the Rhus vernix. This I find to be my own case. After the same exposure, which occasioned the case just detailed, I experienced no ill consequence, except a slight vesicular eruption on the backs of the hands and about the eyes, which disappeared in a short time, without farther inconvenience. The same slight affection I have felt upon several subsequent ex- 
posures, particularly when making, from a recent, specimen, the drawing which accompanies this account.

I apprehend that a majority of persons are not liable to the injurious effects of the poisonous sumacs. Among persons residing in the country, exposures must occur very frequently from the abundance of these shrubs, especially of the Rhus radicans, by roadsides and elsewhere. Very few however, in proportion to the number exposed, have personal experience of their deleterious effects. In those on the contrary, in whom a constitutional liability to the poison exists, the disease frequently returns several times during life, notwithstanding the utmost precaution in avoiding its causes. A gentleman residing in the country informed me, that he had been seven times poisoned to the most violent degree. In such constitutions a slight exposure is sufficient to exeite the disease. I have known individuals badly poisoned in winter from the wood of the Rhus vernix, accidentally burnt on the fire. Others have made the same observation.

Some farther remarks on the poison of these shrubs, and on the treatment of the disease occasioned by them, will be made in a future part of this work, under the head of Rhus radicans. 
Many interesting observations on the properties of these species of Sumach, will be found in an inaugural dissertation, by Dr. Thomas Hors field of Bethlehem, Pa. a work of much industry and merit.

In the New York Medical Repository is an account of a swarm of bees, which, having alighted on the branches of the Rhus vernix, were the next day found dead, with their bodies black and swollen. This is a remarkable circumstance. There is certainly no instinctive aversion in these animals for the tree. In the flowering season the blossoms, which are very fragrant, are always thronged with a multitude of winged insects in quest of their honey.

The introduction of the juice into the arts will not perhaps take place among us, during the present high price of labour, and the general prejudice which exists against the shrub. In some future period, it is probable that a substance, which is found so valuable in the eastern countries, will not be neglected among us. It might safely be procured by persons not subject to the poison, and, with proper precautions, would injure no one during its preparation and use. A pound of the juice in a day might be collected by an individual. When thoroughly dry, it ceases to emit an 


\section{effluvium, and nothing farther is to be apprehend- ed from its effects.}

\section{BOTANICAL REFERENCES.}

Rhus vernix Linneus, Sp. pl.-AITon, Hort. Kerv. i. 366.Michadx, i. 183.-Pursh, i. 205.-Pennated toxicodendron Eulis, Phil. trans. abr. xi. passim. American toxicodendron MrLuer. ibid.-Toxicodendron carolinianum foliis pinnatis, \&c. Mazeas, ibid. x. 595.-Toxicodendron foliis alatis, fructu rhomboideo, Diut. Elth. 390, $t$. 292, f. 377.-Arbor Americana alatis foliis, succo lacteo, venenato, Pudkenet, phyt. t. 145. $f$. 1.

\section{MEDICAL REFERENCES.}

Duduex, Phil.trans. abr. vi. 507.-Sherard, ditto. 508.KaLM, travels, i. 77.-MARshaLL, arbust. 130.-CUTIER, Amer. Acad. 427.-Barton, Coll. 24.-ThaCher, Disp. 321.-HorsFIELD, Inaugural Dissertation.

\section{PLATE X.}

Fig. 1. Rhus vernix, with staminiferous flowers.

Fig. 2. A staminiferous or barren flower magnified.

Fig. 3. Stamens and rudiment of a pistil.

Fig. 4. A fertile flower magnified.

Fig. 5. Germ and stigmas.

Fig. 6. The fruit. 


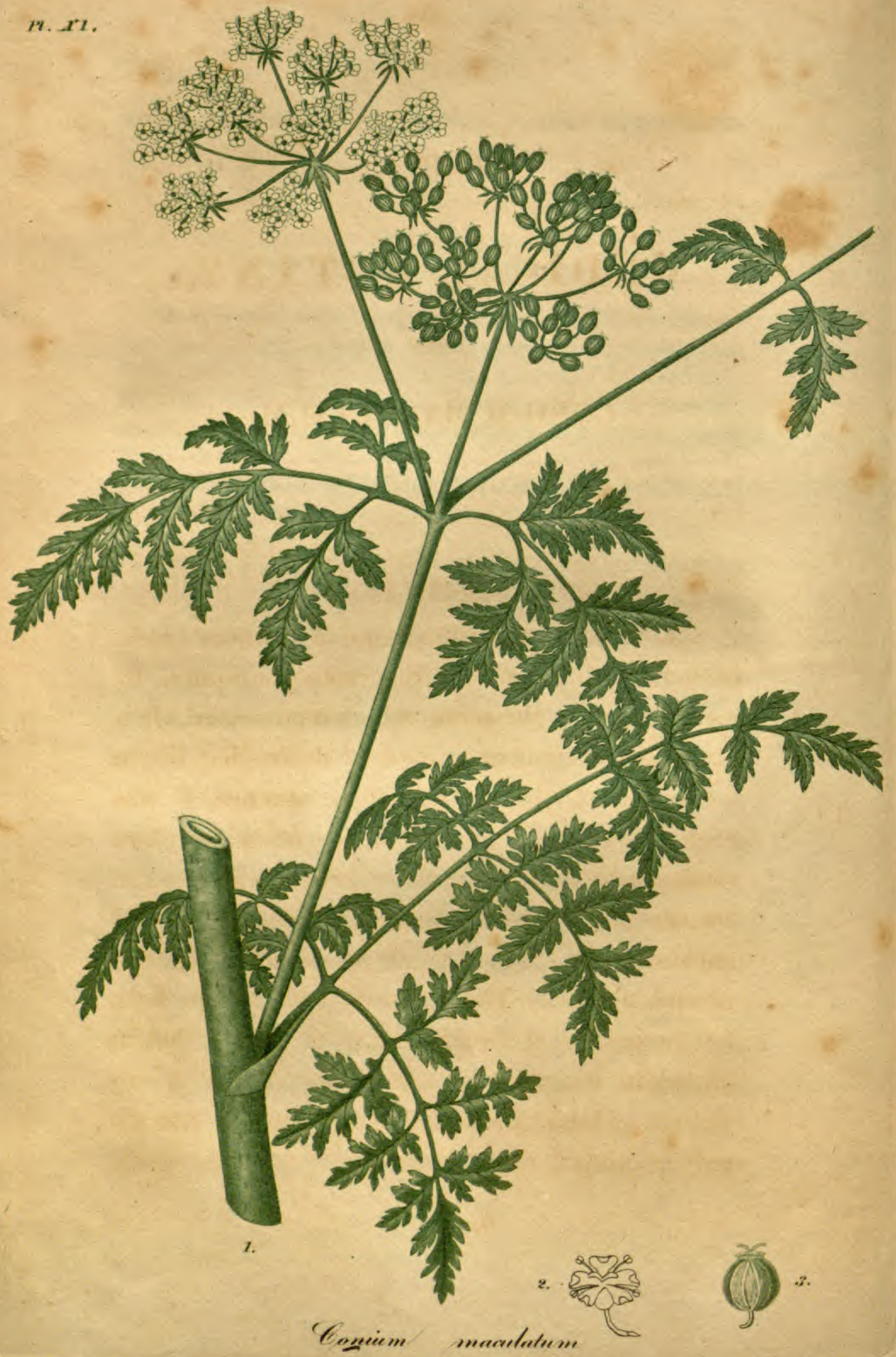




\title{
AMERICAN
}

\section{MEDICAL BOTANY.}

\author{
CONIUM MACULATUM.
}

Hemlock.

$=$
PLATE XI.

A plant bearing the name of Conium, awrecov, has been noted as a poison from remote antiquity. In consequence of the power which it possessed when given in sufficient quantities, of destroying life in a certain and almost immediate manner, it was used at Athens as a mode of execution for those condemned to death by the tribunal of Areopagus. Socrates and Phocion were among the distinguished ancients, who suffered death by the agency of this mortal poison. The accounts which have been left respecting it would lead us to believe that its operation was speedy, and unattended with any violent or long protracted suffering. It was not only employed as an instrument of public execu- 
tions, but was resorted to by those who sought to encounter suicide in its least formidable shape. Among other instances, that of the Cean old men is related by Elian, who when they had become useless to the state, and tired of the infirmities of life ; invited each other to a banquet, and having crowned themselves as in celebration of a joyous festival ; drank the Conium, and terminated their existence together.

The description which has been left by $\mathrm{Di}$ oscorides of the Conium, only shews it to have been an umbellate plant, his character of which might apply to many species. The mention made of it by Latin writers under the name of Cicuta are not more satisfactory. Linnæus, influenced by the noxious character of the modern ofiicinal Hemlock, has appropriated to that plant the name of the Grecian species, and most subsequent botanists have followed his example. Haller, however, is of opinion that the ancient poison was not procured from this plant, but from the Cieuta virosa L. a poisonous aquatic, much more powerful and violent in its operation than the common Hemlock. Lamarek adopts the opinion of Linnæus, and believes that the Conium maculatum was really the Grecian poison, and that its properties were rendered more active by the 
heat of the climate in which it grew. Guersent supposes that the poisonous draught used by the Greeks was not the product of a single species, but a compound prepared from several plants.

Were it not for the tranquillity and ease which attended death from the ancient hemlock, and which Plato has described with interesting minuteness, there would not have been much diffculty in supposing the Grecian plant to be the same with that known at the present day. [Note H.] It appears that a large quantity was requisite to insure death. The poison was swallowed in the crude juice, recently expressed from the plant. Of this the draught taken by Phocion was large enough to cost twelve drachmo.* Socrates was prevented from making a libation of a part of the contents of his fatal cup, by being told that the whole was necessary to produce the consummation of his sentence. A large quantity of the modern hemlock might probably have been equally fatal, though with more violent symptoms than those which, if Plato be correct, were experienced by the Athenian philosopher.

The plant, represented in our plate, undoubtedly came to us from Europe. It is now sufficiently common in the United States, about road

* Plutarch, Life of Phocion. 
sides and in waste ground, especially in those parts of the country which have been longest settled. It is usually found in bunches, and attains the full height of a man. It flowers from June until the arrival of frost.

The very natural order, called Umbellatæ by Linnæus and Umbelliferre by Jussieu, to which this plant and the following one belong, is found in the class Pentandria and order Digynia of the Linnæan artificial method.

The genus Conium of Linnæus has both general and partial involucres, the latter being halved. The fruit roundish and furrozed.

The species maculatum has the fruit unarmed with the ridges undulated.

Its more complete description is as follows. Root biennial, somewhat fusiform and generally branched. Stalk round, very smooth, striated, hollow, jointed, and more or less marked with purplish spots. Leaves two or three times pinnate, of a very bright green, with long, sheathing petioles inserted on the joints of the stem; the leafets pinnatifid and toothed. Flowers in terminal umbels, the general involucre with half a dozen lanceolate, reflected leafets, the partial involucre with three or four situated on the outside. Flowers very small, white. Petals five, oval with their 
points inflexed. Stamens five, spreading, about the length of the corolla. Germ inferior. Styles two reflexed outwardly. Fruit roundish-oval, compressed, ribbed, the ribs being transversely wrinkled or crenate ; separating into two oblong-hemispherical seeds.

Hemlock when fresh has a strong nauseous odour and taste. If the green leaves are distilled, the water which collects in the receiver has an insupportably nauseous taste, while that which remains in the retort is comparatively insipid. This circumstance, and likewise the fact that the dried leaves become inert by age and exposure, render it probable that the chief medicinal efficacy resides in a volatile portion of the plant. Of the more fixed ingredients of Hemlock, a variety of analyses have been made. The most recent which I have met with is that of Schrader, who from a thousand grains of the plant obtained the following substances. Extractive 2\%.3-Gummy extract 35.2-Resin 1.5-Albumen 3.1-Green frecula 8.- He also detected various earthy and alkaline salts. These however are found to vary according to the soil in which the plant grows. The volatile portion, which I obtained in water distilled from the leaves, did not exhibit any essential oil, and effected no change in the colour of litmus. It 
was not altered by sulphate of iron nor acetite of lead.

The Conium maculatum is a nareotic poison, though not of the most powerful kind. Instances of fatal effects from it have been recorded by Dr. Watson in the Philosophical Transactions, and by several other writers. A remarkable case of this sort, which occurred in Spain, is cited by Orfila in his Traité des poisons. But there is scarcely any narcotic plant respecting the character of which such various and opposite testimony has been adduced by medical writers. Even the experiments of the same individual are apt to present different results from its use, unless great care be taken in the collection and preparation of the medicine. The truth is, the plant varies exceedingly at different ages, and in different places of growth, and the strength of its preparations is greatly influenced by external circumstances.

When the green leaves of a mature plant which has grown in the sun, or the juice of these leaves, either crude, or properly inspissated, is taken into the stomach; the following symptoms, if the quantity has been sufficient, will rarely fail to take place; viz. a dizziness of the head and nausea of the stomach, a sense of fullness in the eyes and diminished power of vision, together with 
a general faintness or muscular weakness of the whole body. These sensations usually begin in the course of half an hour. If the dose has been moderate, they will for the most part disappear in the course of half a day, and seldom continue beyond twenty four hours. Larger doses occasion more severe symptoms, as it happens with other narcotics.

The idiosyncrasies of different persons render them variously susceptible of the action of Hemlock. Some are but slightly affected by a quantity, which would prove dangerous to others.

The Hemlock has been for many years a subject of attention with physicians, and has been found a remedy of importance in several diseases. It would occupy a volume to state the whole of the evidences which have been given for and against its use. I shall only mention those complaints in which it has been most employed, and particularly in this country.

In Jaundice.-Dr. Fisher, President of the Massachusetts Medical Society, in his paper on the narcotic vegetables, bears unequivocal testimony in favour of the efficacy of Hemlock in this complaint. He was first induced to employ it with a view to its relaxing effect in facilitating the passage of biliary calculi. Afterwards it was 
given by him to many icteric patients, and with the exception of three complicated cases, it never failed in his hands or within his knowledge to remove the disease. Dr. Jackson, Professor of the Theory and Practice of Physic in our University, informs me that he has found it of great utility in jaundice, and that except in one or two instances, it has always effected the cure of those cases, which proved susceptible of relief from any medicine. I have repeatedly employed it in the same complaint with indubitable advantage. The dose should be gradually increased until its effects are distinctly felt in the head and stomach. This inconvenience is temporary, and will be preferred by most patients to the evil of a mercurial ptyalism. The yellowness of the skin and eyes, in favourable cases, begins to disappear at an early period, frequently by the second day.-The foregoing practice in jaundice is not new, having been employed in Sweden by Rosenstein, and in other places.

In tic doloureux. In a discourse on this painful disease by Dr. Jackson, published in the New England Journal, Vol. II. a number of cases are detailed, in which perfect relief was afforded by the Hemlock given in large doses, and rapidly increased until a decided effect mpon the system was 
felt. Dr. Jackson recommends to begin with a single grain of the extract, and to increase to five grains for the second or third dose; afterwards to add five grains to every dose until a full effect is felt on the system. In this discourse he cites the experience of Dr. Fothergill, who had employed the Conium successfully in several cases of this disease under a different name. It appears also that some French physicians, whose writings I have not seen, as Chaussier and Duméril, have confirmed the success of our plant in tic doloureux. It must be confessed however, although the Hemloek is more successful in this complaint than perhaps any internal medicine, which has been tried; yet there are cases of such obstinacy, as wholly to baffie the powers of its operation.

In schirrus and cancer. Since the time of Storck, this medicine has been long and abundantly tried, but without any increase of reputation. The experience of modern physicians, and among others of M. Alibert, who tried it in more than a hundred eases in the hospital of St. Louis, have pretty well established the fact, that it is wholly ineapable of euring either schirrus or cancer of the confirmed and genuine kind. It is however still administered, rather with a view to its anodyne and palliative effect, than any expectation of radical ben- 
efit. In this way its external use is sometimes serviceable.

In old syphilitic affections, it is occasionally useful. It has been recommended in hooping cough, but it is not a perfectly safe medicine for children, owing to the difficulty of as certaining when its constitutional effects take place in them.-I am informed on the best medical authority, that it is of great use in some cases of hemicrania, which are not regularly intermittent.

The most common form of preserving the Hemlock for use, as well as the most convenient for its exhibition, is that of the inspissated juice or extract. It is well known however, that the extracts kept in our shops differ materially in their strength, so that in beginning from a new parcel, the physician can seldom predict the degree of operation of his first doses. In some instances very great quantities have been taken without the least effect. The extract is apt to prove inert when the plant is gathered too young, when the evaporation is conducted with too much heat, when a decoction of the dried plant has been evaporated instead of the fresh leaves, and lastly when the extract itself has become old. To give the extract its due strength, the plant should be collected at full maturity, while in flower, or in fruit provided it remains green, and 
the juice or the decoction should be evaporated at the heat of boiling salt water. The stock should be renewed every year. A suitable dose for commencement is from one to five grains. This may be increased at every time of taking it, until its constitutional effects are felt. In beginning the use of a new parcel, more caution is requisite at first, than after its strength has been tested.

The Fthusa cynapium, an umbellate plant very common in Boston, has sometimes been mistaken for Hemlock, which it considerably resembles. It is a smaller plant, with its stalk not spotted. It differs also in having no general involucre, while its partial one is very long.

\section{BOTANICAL REFERENCES.}

Conium Maculatum, Linneus. Sp. $\boldsymbol{P l}$.-Woonvibue, $t$. 22.Curtis, Fl. Lond. i. 17.-Sмith, Engl. Bot.t. 1191.-Pursh, i. 195.-Cicuta vulgaris, MoRIson, Umb. t. 6.-PARKinson, Theatr. 9s3.-Cicuta major, Laмarck, Encyclopedie Methodique.-Cicutaria vulgaris, Cuusrus, Hist. 200.

\section{MEDICAL REFERENCES.}

Murray, Apparatus medicaminum, i. 322.-Culden, Mat. Med. ii. 263.-Fothergili, Med. Obs. iii. 400.-Hunter on the venereal, 108, 175, 199, 247, \&c.-Hoмe, Annals Med. iii. 66.-BuTter, Med. Comment. i. 37 3.-Fisher, Mem..Mas. Soc. i.-JACKson, N. Engl. Journ. ii. 105.-Guersent. Dict. Sciences Medicales, v. 208.-OrfiLA, Toxicologie, iii. 279, \&c. \&c. \&c. 


\section{PLATE XI.}

Fig. 1. A branch of Conium maculatum. Fig. 2. Flower magnified.

Fig. 3. Fruit magnified. 


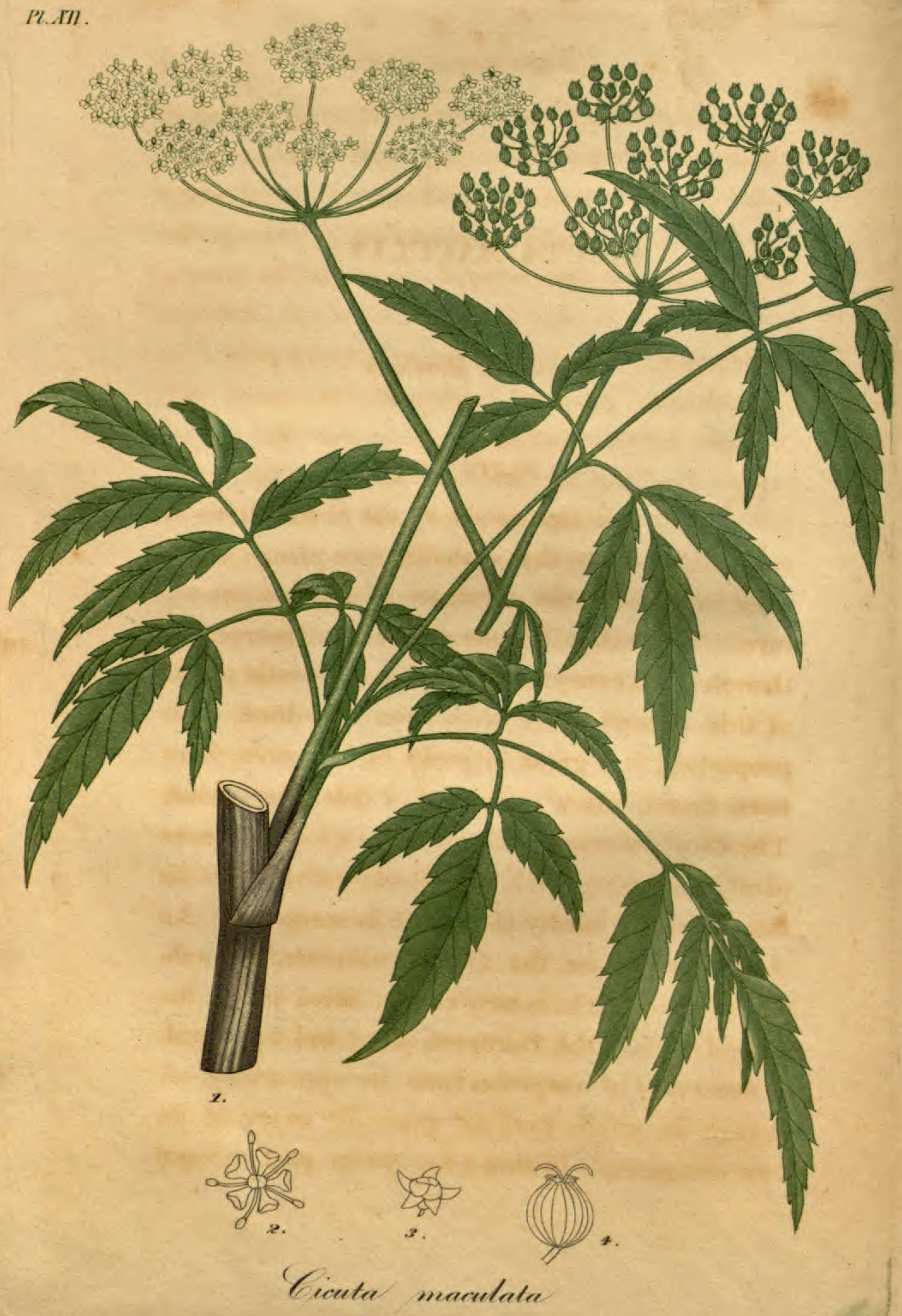




\section{CICUTA MACULATA.}

American Hemlock.

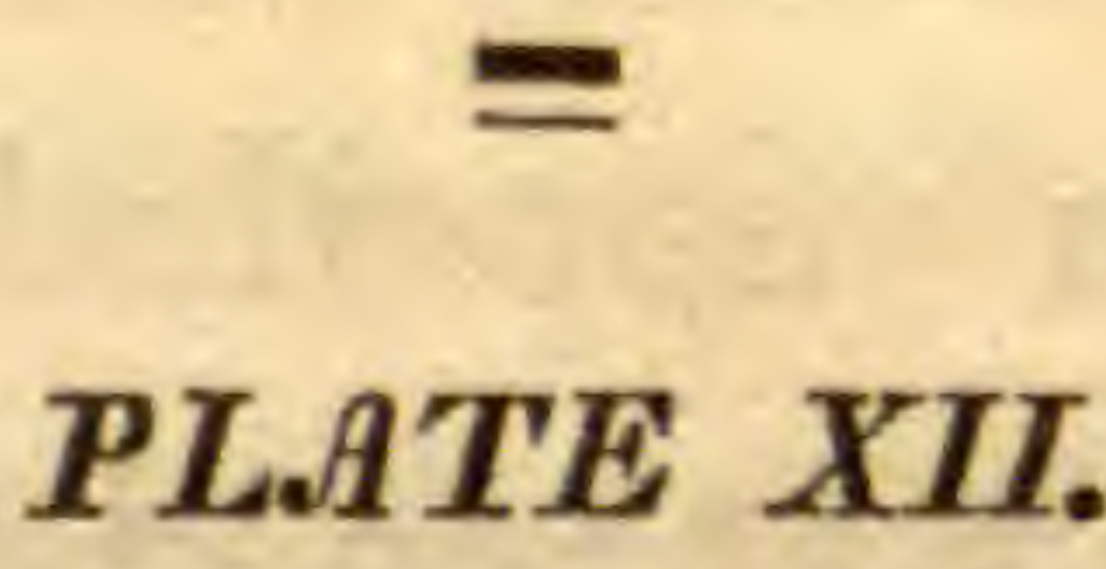

$\mathbf{I}_{\mathrm{T}}$ is a rule sanctioned by the observations of medical botanists, that umbelliferous plants, which grow in or about the water, are of a poisonous nature. This rule will generally be found correct, although it has exceptions. As far as aquatic plants of this natural order have been examined, their properties, in a great majority of instances, have been found, more or less of a deleterious kind. The Cicuta virosa of Europe is a highly poisonous plant, possessing such formidable activity that its internal use is hardly attempted in medicine. An American species, the Cicuta maculata, the subject of this article, is very closely allied in its botanical habit to the European plant, and was equally deserving of suspicion from its appearance, although the public were not generally aware of its true character. Within a few years past, several 
instances have been brought to light of fatal effects ensuing from this plant being incautiously eaten by children. It is therefore necessary that the species should be suitably designated, that a source of so much danger may be known and avoided.

The Cicuta maculata, to which I have applied the name of American Hemlock, not having heard any common appellation except that of Snakerveed, inhabits wet meadows and banks, from the northern to the southern limits of the United States, flowering in July and August. It is so frequently cut with hay, among which it often grows in large quantities, that we might expect to see its deleterious properties operating on domestic cattle, were it not that their bodies are probably less susceptible of its poison than ours. The European Cicuta, above mentioned, is highly noxious to man, and to some domestic animals, yet goats and sheep eat it with impunity.

The genus Cicuta differs from other genera of umbellate plants in having no general involuere, a short, partial involucre, and a fruit which is nearly orbicular, compressed and furroved.

* This description of the fruit agrees with the present species and also with Cicuta bulbifera, a smaller species not uncommon about Boston. The Cicuta virosa of Europe I have never seen. 
The species maculata has a fascicled root and oblong leaves with mucronate serratures.

The class and orders are as in the last article. This plant is so remarkable for the form of its root, that had not the name of maculata been confirmed to me by the best authorities, I should have thought that of fasciculata to be greatly preferable. This root is composed of a number of large, oblong, fleshy tubers, diverging from the base of the stem, and frequently being found of the size and length of the finger. The root is perennial, and has a strong, penetrating smell and taste. In various parts of the bark it contains distinct cells or cavities, which are filled with a yellowish resinous juice. The plant is from three to six feet high. Its stem is smooth, branched at top, hollow, jointed, striated, and commonly of a purple colour, except when the plant grows in the shade, in which ease it is green. The leaves are compound, the largest being about three times pinnate, the uppermost only ternate. Most of the petioles are furnished with long obtuse stipules, which clasp the stem with their base. Leafets oblong acuminate, serrate, the serratures very acute or mucronated. The veins end in the notches, and not at the points of the serratures. The flowers grow in umbels of a middling size, without a general invo- 
lucre. The partial umbels are furnished with involucres of very short, narrow, acute leafets. The distinctness or separation of these umbels characterizes this plant at a distance among other plants of its kind, whose umbels are more crowded. Calyx of five very minute segments. Petals five, white, obovate with inflected points. Fruit nearly orbicular, compressed, ten furrowed, crowned at top, and separating into two semicircular seeds.

The fleshy root of the Cicuta maculata, when pressed, emits from its divided extremities a viscid yellowish juice of a strong penetrating taste. This juice dissolves in alcohol, from which it is precipitated by water. When distilled, a thick volatile oil collects in the receiver in the form of a film upon the surface of the water. The remainder of the juice yields a resin of a dark orange colour, fusible and inflammable. The decoction of the root affords a pearl coloured fluid, not very sensible to the tests of mucus, fæcula, tannin or extractive.

In August 1814, an account was sent to Boston by Dr. Stockbridge of Bath (Maine) of the effect produced on three boys by eating a poisonous root, which they had dug up, supposing it to belong to the plant called "Life of man." One of them was siezed with violent convulsions, frothed 
at the mouth, and died in an hour and a half. The other two were affected with vomiting, stupor, dilatation of the pupil, great paleness and universal distress; which symptoms disappeared in one in twenty four, and in the other in thirty six hours. It was supposed that the first boy had swallowed about a drachm of the root, and the others about half that quantity. A specimen of the plant was sent to me at the same time with the account, and proved to be the Cicuta maculata. Dr. Stockbridge's letter, which was published in the New England Journal, contains two other cases of the effect of this root, in one of which it proved fatal.

Shortly after the publication of the above facts, an article appeared in the New York Medical Repository, containing an account by Dr. Ely of Dutchess county, of the effects of an unknown poisonous root, supposed to be the white hellebore. Three small boys, who had gone into a meadow in search of sweet flag root, had dug up and eaten another root by mistake. Two of them died in convulsions in about an hour after they had swallowed it. They discharged much, blood and froth from the mouth and nose; their eyes were fixed, with the pupils dilated, and a rapid motion of the eye lids. The third boy vomited, and recovered. When taken to the place the next 
day, he pointed out the spot where they had dug the root, and where a considerablc quantity of it remained. Some of the root was planted by Dr. Mitchill in the New York Hospital garden, where it vegetated and produced flowers and fruit. It turned out to be the Cicuta maculata of Linnæus. In the same article, is a letter from Dr. Muhlenberg, stating that he had received specimens from Savannah and from West Pennsylvania, where it had destroyed several persons, who ate it by mistake for angelica. All the specimens were similar, so that there could be no doubt of the identity of the plant. In the same letter, Dr. Muhlenberg remarks, that he had reason to believe that the poisonous quality of the root is altered by cultivation in a dry soil.

The foregoing facts are sufincient to establish the poisonous character of the plant under consideration. They may also serve to shew the importance of accurate descriptions and faithful engravings of noxious vegetables, which may enable even unlearned observers to distinguish them at sight. There ean be little doubt that cases, like those above described, have occurred in repeated instances, which have never met the public eye. Perhaps also from an ignorance of the real cause of the symptoms, the proper remedies have been 
neglected. The plant is extremely common in many parts of the United States, and I believe its true character is not generally suspected. A very respectable physician informed me, that it was used in his vicinity as a gargle for sore throats, by people unsuspicious of its qualities.

Since the discovery of its narcotic properties, the Cicuta has been used in small doses, as a substitute for the conium, by one or two practitioners in this place. Its effects were very analogous to those of the true hemlock, as far as they were observed, but more powerful. A primary symptom, which attended a large dose, was nausea and vomiting.

The treatment of persons poisoned by this plant, as in the case of other narcotics, should primarily consist in a thorough evacuation of the stomach. As there commonly exists a spontaneous tendency to vomit, occasioned by the poison itself, this should be assisted by mechanical means, by irritating the throat with the finger, or with a feather. Of emetics; the sulphate of zinc is to be preferred, on account of its speedy operation. Castor oil or infusion of senna, should be given as soon as vomiting has taken place. The vegetable acids, such as lemon juice or vinegar, have a neutralizing influence on the narcotic, and are therefore useful. Strong coffee and tea are the best an- 
tidotes for the stupor, and should be promptly administered. In violent cases, bloodletting should be resorted to. As most narcotic poisons act by destroying the functions of the brain, respiration being suspended, because it is under the influence of that organ; Mr. Brodie is of opinion, that in some cases, life might be preserved by keeping up artificial respiration, after death has apparently taken place.

\section{BOTANICAL REFERENCES.}

Cicuta maculata. Linneus $S p$. pl.-Pursh, i 195.— dium foliis lanceolatis, acuminatis, serratis. Grovovrus, Virg. 32.-Angelica Caribæarum elatior, olusatri folio ; flore albo ; seminibus luteis, striatis, cumini odore et sapore? Plukenet, .Alm. 31, Phyt. t. 76, f. 1 .

\section{MEDICAL REFERENCES.}

Schepf, 36.-Bart. Coll. 18, 46.-Stockiridge, New Engl. Journal, iii. S34. Mitchil, Eix and MuhLeneerg, Med. Repository, xvii. 303. 


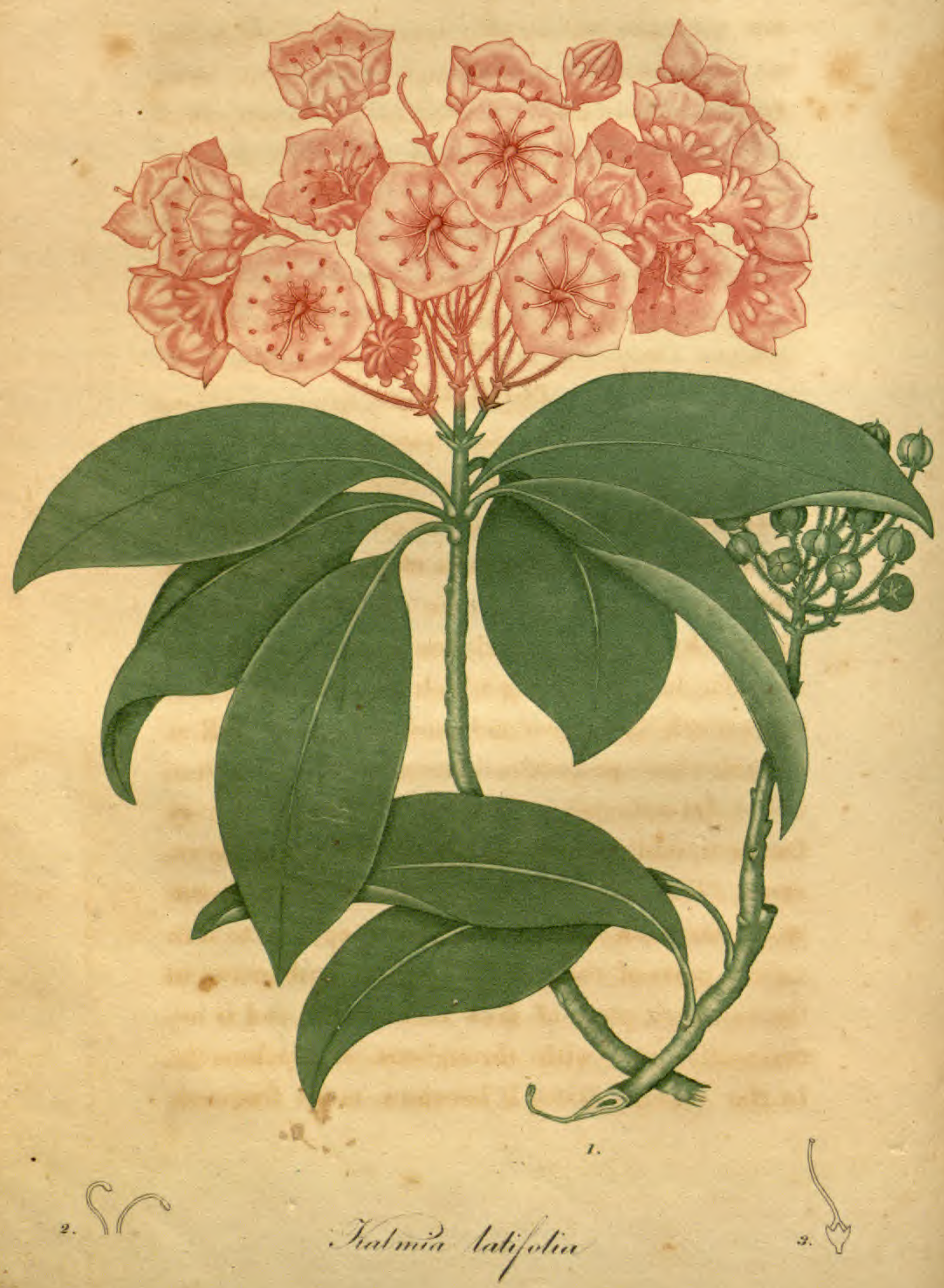




\section{KALMIA LATIFOLIA.}

Mountain laurel.

\section{$=$ \\ PLATE XIII.}

The Swedish botanist, Peter Kalm, a pupil of Linnæus, who travelled in North America in 1748 - 9, has had the honor of giving name to one of the most elegant genera of flowering shrubs which our continent produces. The genus named Kalmia by Linnæus, includes several species, of singular beauty, among which the Mountain laurel is much the largest and most elegant, as well as the one whose properties have received most attention. Its occurrence in the United States is very frequent, and its common appellations of course various. The names of Laurel, Lambkill, Ivy, Spoonwood, and Calico bush, it seems, are applied to it in various parts of the country. This shrub grows in the southern parts of New Hampshire, and is occasionally met with throughout Massachusetts. In the Middle States it becomes more frequent, 
and it is said to extend near to the southern limits of the Union. Michaux, in his account of the forest trees, states, that it is particularly abundant through the whole range of Allegany mountains, upon the borders and near the sources of rivers. It gradually diminishes however on both sides as these rivers approach to the sea, or to their confluence with the great western streams.

The botanical character of the genus consists in a five parted calyx, a hypocrateriform corolla, containing ten depressions in its border, in which the anthers are lodged; a capsule five celled.

The specific character is, that the leaves are scattered, petioled, oval and smooth; the corymbs terminal, viscid and pubescent.

Class Decandria, order Monogynia. Natural orders Bicornes, Linn. Rhododendra, Juss.

The height of the Kalmia latifolia is generally that of a shrub, sometimes however attaining to the altitude of a small tree. Its leaves are evergreen, coriaceous, very smooth, with the under side somewhat palest. Their form is oval, acute and entire ; their insertion by scattered petioles, on the sides and extremities of the branches. The flowers vary from white to red; they grow in terminal corymbs, simple or compound with opposite branches, and made up of slender peduncles. These 
are invested with a glutinous pubescence, and supported at base by ovate, acuminate bractes. The calyx is small, five parted, persistent, with oval, acute segments. The corolla is monopetalous, with a cylindrical tube, a spreading dise, and an erect, five cleft margin. At the circumference of the disc on the inside, are ten depressions or pits, accompanied with corresponding prominences on the outside. In these depressions the anthers are found lodged at the time when the flower expands. The stamens originate from the base of the corolla, and bend outwardly, so as to lodge their anthers in the cells of the corolla. From this confinement they liberate themselves during the period of flowering and strike against the sides of the stigma. The germ is roundish, the style longer than the corolla and declined, the stigma obtuse. Capsule roundish, depressed, five celled and five valved, with numerous small seeds.

I have examined chemically the leaves of the Kalmia, gathered at the time the shrub was in fruit. The following constituent principles were found to exist in them.

1. Vegetable mueus. This exists in large quantities, and is dissolved in water both by infusion and decoction, rendering it extremely mucilaginous or ropy. When alcohol is added to this so- 
lution, the mucus separates in the form of a flocculent coagulum, which is tough and stringy, and on drying has a brownish colour. When chewed, it soon fills the mouth with mucilage.

Silicated potash rendered the upper stratum of the liquid dark and opaque, but without any precipitate like that which takes place in the mucilage of gum.

2. Tannin. This is readily thrown down from the decoction and tincture by gelatin. The sulphate of iron strikes with it a very black colour.

3. Resin. This also exists plentifully. It communicates to alcohol a reddish colour, and is instantly precipitated from it by water. When obtained pure, it is of a reddish east, fusible, inflammable and moderately bitter.

I have not detected any extractive, properiy so called, in these leaves. When the muriate of tin is added to the decoction, it separates a very copious yellow precipitate. This however is owing to the mucus. If alcohol be first added to the decoction, and the coagulum which it forms withdrawn; the fluid no longer gives a precipitate with muriate of tin, although it readily yields one to gelatin.

Distillation with water affords a mild fluid with little taste or odour. 
The Kalmia latifolia, together with some other species of its genus, has long had the reputation, in various parts of the country, of being poisonous to certain domestic animals. Catesby says of it, that "deer feed on its green leaves with impunity; yet when cattle and sheep, by severe winters deprived of better food, feed on the leaves of this plant, a great many of them die annually."

Kalm, the Swedish traveller, who gave name to this genus, says of Kalmia latifolia, "The leaves are poison to some animals, and food for others; experience has taught the people, that when sheep eat of these leaves, they either die immediately, or fall very sick, and recover with great difficulty. The young and more tender sheep are killed by a small portion, but the older ones can bear a stronger dose. Yet this food will likewise prove mortal to them, if they take too much of it. The same noxious effect it shews in regard to calves which eat too much of the leaves; they either die, or do not recover easily. I can remember that in the year 1748 some calves ate of the leaves; they fell very sick, swelled, foamed at the mouth and could hardly stand; however, they were cured by giving them gunpowder and other medicines. The sheep are most exposed to be tempted with these leaves in winter, for after having been kept in sta- 
bles for some months, they are greedy of all greens, especially if the snow still lies upon the ground, and therefore the green but poisonous leaves of the Kalmia are to them very tempting. Horses, oxen and cows, which have eaten them, have likewise been very ill after the meal, and though none - of them ever died of eating these leaves, yet most people believed, that if they took too great a portion of them, death would certainly be the result." "On the other hand, the leaves of the Kalmia are the food of stags, when the snow covers the ground and hides all other provisions from them. Therefore, if they be shot in winter, their bowels are found filled with these leaves, and it is very extraordinary, that if those bowels are given to dogs, they become quite stupid, and, as it were, intoxicated, and often fall so sick, that they seem to be at the point of death; but the people who have eaten the venison have not felt the least indisposition."-Travels in .North America, vol. i.

There is a common belief, that the flesh of the American Pheasant or Partridge is at certain times imbued with a poisonous quality. This circumstance has been attributed (I know not with what evidence) to their feeding in winter upon the buds of the Kalmia. Mr. Wilson, the ornithologist, informs us, that he has sometimes found the 
crops of these birds distended almost entirely with laurel buds; but that he has eaten freely of the flesh of these very birds, without any ill conse. quence whatever.

On the human system, the Kalmia has been also said to manifest a deleterious influence. The late Professor Barton has adduced some evidences of its noxious character. ${ }^{*}$ He states that the Indians make use of a decoction of the leaves to destroy themselves. In an Inaugural Dissertation on two species of Kalmia, the latifolia and angustifolia, by Dr. G. K. Thomas, we are told that the leaves of these shrubs possess a decidedly narcotic property. I have not recently seen Dr. Thomas' Dissertation, and therefore quote from memory and from extracts. From his experiments however it appeared, that a very small quantity was sufficient to produce sensible ineonvenience. Thirty drops of a strong decoction, given six times a day, are said to have occasioned so much vertigo, as to render it necessary to diminish the frequency of its exhibition.

From my own experience, I am not disposed to think very highly of the narcotic power of the

* Dr. Barton states, that a few drops of the tincture poured upon the body of a large and vigorous rattlesnake, killed the reptile in a very short time. 
Kalmia. I have repeatedly chewed and swallowed a green leaf of the largest size, without perceiving the least effect in consequence. I have also seen the powder, freshly made from leaves recently dried, taken in doses of from ten to twenty grains, without any subsequent inconvenience or perceptible effect. The taste of these leaves is perfectly mild and mucilaginous, being less disagreeable than that of most of our common forest leaves.

I am inclined to believe that the noxious effect of the Kalmia upon young grazing animals may be in some measure attributed to its indigestible quality, owing to the quantity of resin contained in the leaves.

An ointment made of the powdered leaves has been recommended in tinea capitis and some other cutaneous affections. I have seen an eruption, very much resembling psora, removed by it.

The wood of the Kalmia is hard and dense, approaching in its character to that of box. It is much used for the handles of mechanics' tools, \&.c. and it has even been employed as a material for musical instruments. As an ornamental shrub, this speeies stands in the highest rank, and by the frequency of its growth and the brilliancy of its flowers, it contributes in a great degree to the elegance of the natural scenery in those mountains 
and woods, which it inhabits. When cultivated in gardens, it requires a soil which is somewhat moist, and a shady or northern aspect.

\section{BOTANICAL REFERENCES.}

Kalmia latifolia, Liv. Sp. pl.-Curtis, Bot. .Mag. $t$. 175.Michaux $f$. Arbres forestiers, iii. 147, t. 5.-Punsh i. 296.-Chamædaphne foliis tini, \&c.-Catess floribus bullatis. \&c. Trew, $t$. 38.-Cistus chamærhododendros, \&c. Plukenet, Phyt. t. 379, f. 6.

\section{MEDICAL REFERENCES.}

KatM, truvels, i. 335 , \&c.-Bart. Coll. i. 18, 48 ; ii. 26.Thacher, Disp. 247.-Thомas, Inaugural dissertation.

\section{PLATE XIII.}

Fig. 1. Branches of Kalmia latifolia with flowers and fruit.

Fig. 2. Stamens.

Fig. 3. Calyx and pistit. 


\section{SPIGELIA MARILANDICA.}

Carolina Pink root.

PLATE XIV.

$W_{E}$ are told by different writers, that this fine plant is a native of all the southern states from Pennsylvania to Georgia and Louisiana, growing in rich soils, especially about the borders of woods. It does not bear the severity of a northern winter. For my living specimens I was indebted to my excellent and learned friend, the late Dr. James Macbride, of Charleston, S. C.

The genus Spigelia has a funnel shaped corolla and a capsule, which is double, two celled and many seeded. The species Marilandica is perennial, with a simple stem and opposite leaves.

Class Pentandria; order Monogynia. Natural orders Stellata, Lin. Gentiance, Juss.

The root of the Spigelia Marilandica is perennial, with many fibrous branches. The stalks proceed several from a root; they are simple 


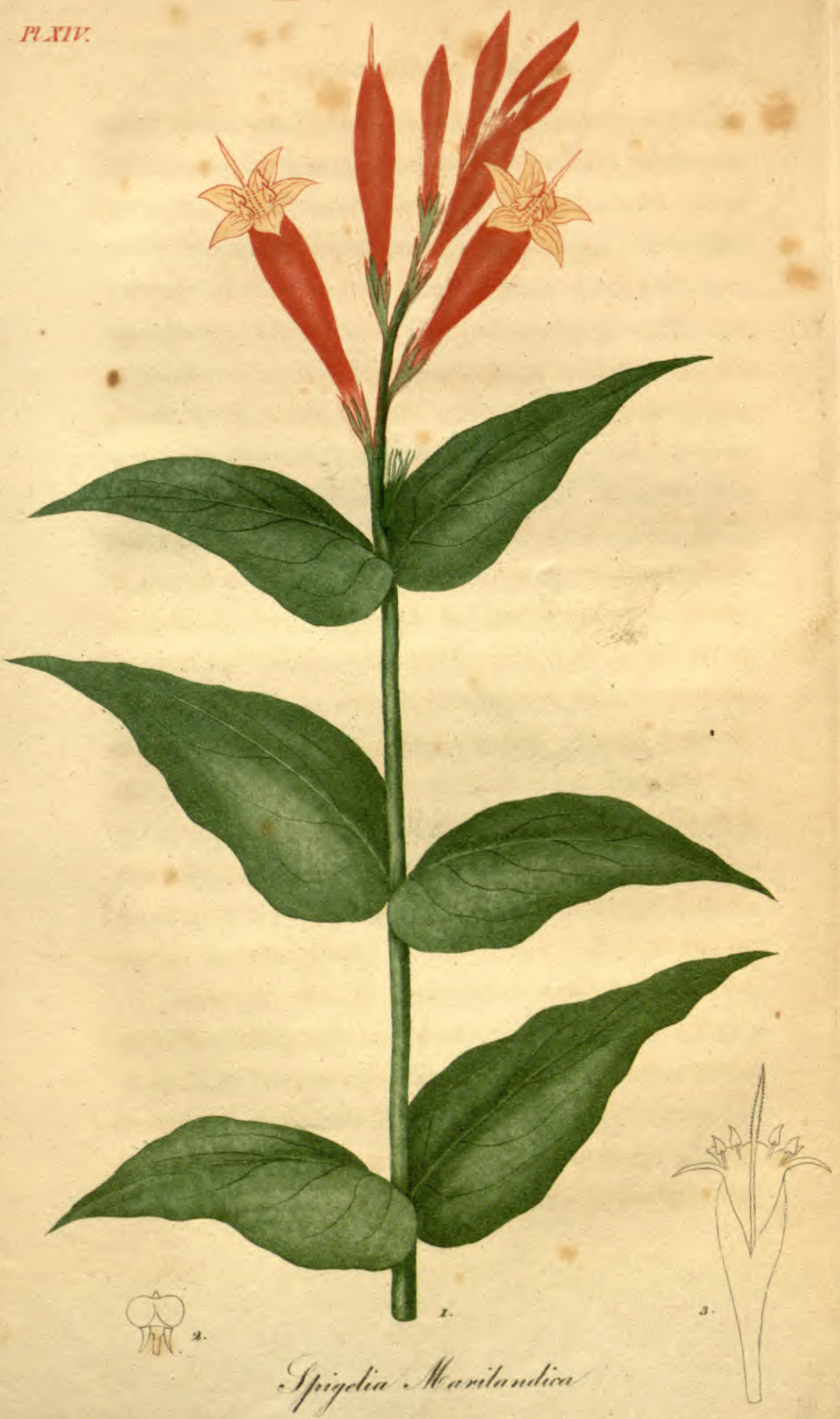


four sided and nearly smooth. Leaves opposite, sessile, ovate, acuminate, entire, smooth, with the margins and veins sometimes pubescent. The stalk commonly terminates in a simple one-sided raceme of flowers, although I have seen luxuriant specimens with two. The peduncles are extremely short, so that the raceme may without impropriety be denominated a spike. Calyx persistent, with five linear-subulate, finely serrulate leaves, which are reflexed in the ripe fruit. Corolla five times as long as the calyx, scarlet or crimson without, orange coloured within, the tube inflated and angular at top, the border divided into five acute, spreading segments. Stamens very short, inserted into the mouth of the corolla between the segments; anthers oblong-heart shaped. Germ small, superior, ovate. Style longer than the corolla, jointed near its base and bearded at the extremity. Capsule double, consisting of two, cohering, one celled, globular portions, seated on a common receptacle.

The Spigelia is a mucilaginous plant, with a mild and not very disagreeable taste. The infusion and decoction of the root and leaves afford a flocculent precipitate with alcohol. They are discoloured but not precipitated by silicated potash. They have little sensibility to gelatin, al- 
though the tincture is made turbid by it. After the decoction was filtrated from the mucus, which had been coagulated by alcohol, it gave a precipitate with nitrate of mercury, but none with muriate of tin. Sulphate of iron caused a dark green precipitate from the decoction, and but little change in the tincture. No distinct evidence of resin presented itself. A substance which may perhaps be considered a variety of extractive matter, appears to exist in this plant, as the tincture was affected in nearly the same manner by the salts of tin and mercury above mentioned, as the filtrated decoction.

Water may be considered an adequate solvent for the chief proximate principles of this plant.

The medicinal reputation of the Spigelia is founded on the powers which it is supposed to possess as a vermifuge. This reputation is now so generally established, that the plant has become a considerable article of commerce to various parts of the world, from our southern states. This is a sufficient evidence, that the medicine has, to a certain extent, satisfied public expectation, and obtained the sanction of practitioners. But beyond this, it is difficult to speak confidently on the subject. The Spigelia belongs to a class of medicines, which are frequently prescrib. 
ed, without positive proof of the existence of the cause which they are intended to remove; which often fail altogether in the hands of the most successful practitioners; which frequently succeed merely because they are backed with medicines of a more active class ; and whose apparent success is sometimes the consequence solely of a diseased state of the body.* Our plant is however entitled to trial, especially where it can be obtained fresh, and in full strength. A physician of the southern states, for whose opinion $\mathrm{I}$ have much respect, Dr. Norcom of Edenton, N. C. informed me some years since, that the Spigelia was

* From the list of equivocal anthelmintics, I would except those which have a cathartic operation, also a number of mineral origin. But I am fully persuaded, that many reputed vermifuges have enjoyed a reputation which they do not deserve. The Dolichos pruriens has received the cominendations of practitioners and medical writers, on the presumption that its spiculæ exert the same stimulant effect on the bodies of worms in the alimentary canal, that they do on the numan skin externally. I was long ago inclined to doubt the power of these spicula to withstand the digestive process of the stomacb. My suspicions were confirmed upon finding that simple maceration in warm water for an nour, dissolves their virus, and renders them incapable of producing their usual stimulus of itching, when applied to the shin. Some late experiments by my pupil, Dr. Chandler, have shewn that the gastric juice destroys their activity in the same manner.

It is not necessary in this place to revert to the Fern root of Madame Nouffer, and various other exploded anthelmintics of its kind. 
most active when recently dried, and that its efficacy was always impaired by keeping more than six months. Dr. Garden had previously made observations somewhat similar. If this be the case, we may account for its failures in the hands of those who obtain it at a distance when half a dozen years old.

Drs. Lining, Garden, and Chalmers of Carolina, are the writers who first introduced the Spigelia to notice, and who have spoken most unequivocally in its praise. Each of these physicians has represented it as an anthelmintic of superior efficacy. It appears that under certain circumstances, it is capable of operating as a cathartic, and that in these instances, the most advantage has been experienced from it. Dr. Garden says, that he had given it in hundreds of cases, and that he "never found it do much good except when it proved gently purgative." As the action of the Spigelia upon the bowels is quite uncertain, most practitioners either unite, or follow it with calomel or some purgative medicine.

We are told that the pink root, when in its most active state, if given in large quantities, induces narcotic symptoms, such as stupor, headach, dilated pupil, \&c. Dr. H. Thompson, who took large doses of the root to try its effect on himself, 
found that it produced an increased quiekness of the pulse, drowsiness, flushing of the face and stiffness of the eyelids. Dr. Chalmers attributes to its too free use the cases of two children, who died in convulsions. Dr. Macbride informs us that its narcotic effects are seldom or never attended with danger, and that some physicians consider them an evidence of the favorable operation of the medicine. The opinion that this effect is owing to the root of some deleterious plant taken up with the Spigelia, seems to be void of foundation.

As in most other perennial plants, the root of the Spigelia possesses a greater share of activity than the herb. Of this root ten grains may be given in powder to a child four years old, twenty to one which is seven, and a drachm to an adult. If no inconvenience ensue, it may be repeated two or three times a day. If the infusion is preferred, an ounce of the root may be infused in a pint of water, and half the quantity taken by an adult or one or two spoonfuls by a child.

BOTANICAL REFERENCES.

Spigelia Marilandica, Lins. Sp. pl.-CurTis, Bot. Mag. $t$. 80.-Woodvile, ii. t. 105.-W WLter, Flor. Car. 92.-MIchuex, i, 147.-Pursh, i. 139.-Euhiotт, i. 236.-Lonicera 
spicis terminalibus, \&c. Gronov. Virg. 30.-Periclymeni Virginiani flore coccineo planta Marilandica, \&c. Catesb , ii. $t .78$.

\section{MEDICAL REFERENCES.}

Chammers, on the weather and diseases of South Carolina, i. 67.-Lining, Essays, phys. and lit. i. 436. Garden, ditto, iii. 145.-Home, Clin. exper. 420.-Murray, App. .Med. i. 548MACBRIDE, in Elliott's Car. 237.-Thompson, Inaug. Diss.

\section{PLATE XIV.}

Fig. 1. Spigelia Marilandica.

Fig. 2. The capsule with the reflected calyx.

Fig. 3. Corolla opened. 


\section{PLIV.}
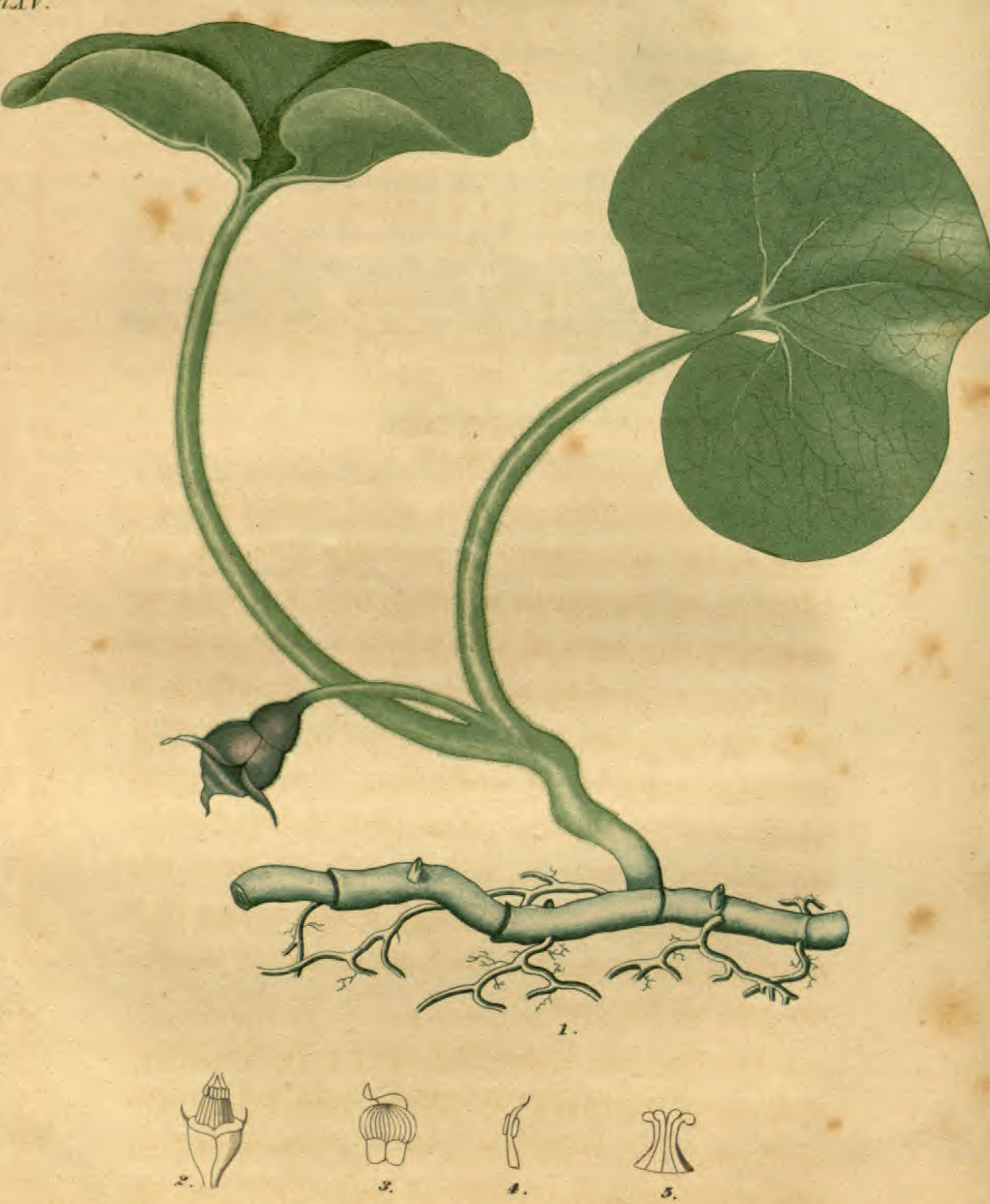

ses

tormeme Connademse 


\section{ASARUM CANADENSE.}

Canada Snake root. Wild ginger.

\section{PLATE XV.}

The properties of this mild aromatic have been so far misconceived, probably from its relation to an European species, that it would be improper in a work of this kind, to pass over it without notice of its real character. It affords a striking exception to the rule, that botanical affinities are capable of indicating the medicinal qualities of vegetables. This plant in its effect on the human system, is widely different from the European asarabacea, although it approaches it so nearly in its form, that Michaux styles it "vix distinctum ab Europæo."

The Asarum Canadense grows in old woods and mountainous tracts from Canada to Carolina. It is one of the humblest plants, presenting only two leaves with their stalks, which appear to constitute the whole of the plant above the ground. 
On plucking the plant, the two leaves are found connected below, with an obscure flower in their fork, which had rested on the surface of the ground, or been buried under the decayed leaves and soil. Its flowering time is from May to July.

This plant, from the number of its stamens, is placed by Linnæus and Michaux in the class Dodecandria. Pursh, who has omitted this class in his Flora, has transferred the Asarums to Gynandria, from the circumstance that the stamens are inserted on the germ. This place however is not better suited to the Asarum, than to a multitude of other plants whose germ is inferior.

Linnæus' natural order for this plant is Sar- mentacex and Jussieu's Aristolochice.

Generic character. Calyx three or four cleft, superior; corolla none; anthers growing to the middle of the filaments. Capsule coriaceous, crowned.

Specific character. Leaves troo, reniform; calyx woolly, cleft to the base; its segments spreading at top.

The root of the Asarum is creeping, fleshy, and somewhat jointed. Leaves kidney shaped, pubescent on both sides, with long, round, hairy petioles. Flower solitary, growing from the fork of the stem, on a pendulous hairy peduncle. $\mathrm{Ca}$ - 
lyx very hairy or woolly, consisting of three broad, concave leafets, which are mostly of a brownish or dull purple on the inside at top and bottom, and terminated by a long, spreading, inflected point, with reflexed sides. The colour varies greatly according to the amount of light which the plant enjoys, being sometimes nearly green. Stamens twelve, inserted on the germ at a distance from the calyx, the alternate ones longer. Anthers growing to the filaments below their extremity. Near the divisions of the calyx are three short, curved, filamentary substances, which may perhaps be called nectaries. Germ inferior, somewhat hexagonal, marked at top inside with a dark red line; style conical, striate, parted at top into six recurved, radiating stigmas.

The root of the Asarum has an agreeable aromatic taste, which is intermediate between that of ginger and the aristolochia serpentaria. This quality has given it the names of Wild ginger and Snake root in different sections of the country. The name Colt's foot is also applied to it.

The chemical trials, to which I have subjected the root, bring to view the following substances:1. A light coloured, pungent, volatile oil, possessing the characteristic taste and smell of the plant in a high degree. 2. A resin, which is of a red- 
dish colour and very bitter. These two constituents communicate to alcohol the active properties of the plant. 3. Focula. 4. A gummy mucus. These exist in such quantities as to impede the filtration of the decoction. Astringency hardly exists in this root, as a gelatinous solution gave no evidence of tannin, and the sulphate of iron produced a green colour hardly bordering on black.

It has been asserted, and the statement copied from one book to another, that the Asarum Canadense is a powerful emetic. I presume that subsequent writers have taken their opinion from Cornutus, who, in his plants of Canada, informs us, that two spoonfuls of the juice of the leaves of the Asarum, (meaning the European plant, rather than the American,) are found to evacuate the stomach powerfully. I can hardly doubt, that if such an operation has really been produced from the Canadian species, it must have taken place in irritable stomachs, to whom two spoonfuls of any crude vegetable juice would have proved emetic. Having seen the root of this plant used in the country in considerable quantities as a sudorific, I was long since induced to doubt its emetic power. Subsequent experience has satisfied me that the freshly powdered root, given to the extent of half a drachm, and probably in still 
larger quantity, excites no vomiting nor even nausea.

Still however the plant deserves not to be discarded from use. The aromatic flavour of the root is more agreeable than that of the aristolochia serpentaria, which article it seems to resemble in its medicinal powers. Several country practitioners, who have employed it, have spoken to me favourably of its effect, as a warm stimulant and diaphoretic. As a substitute for ginger, in common domestic use, I know of no indigenous article which promises so fairly as this.

Alcohol is the proper solvent for the active properties of this plant. The tincture has a dark red colour, and a highly concentrated taste of the root.

\section{BOTANICAL REFERENCES.}

Asarum Canadense, Lrv. Sp. pl.-Mrchaux, i. 279.-Pursh, ii. 596.-Asarum foliis reniformibus, mucronatis, binis, Grovovus, 72.-Asaron Canadense, Cornutus, Canad. 24, t. 25.Asaron Americanum, PARkinson, theatr. 266.

\section{MEDICAL REFERENCES.}

SCHËP, 72.-BART. coll. 26, 48.-CoXe, Disp. 368. 


\section{PLATE XV.}

Fig. 1. Asarum Canadense.

Fig. 2. The germ with the stamens and nectareous filaments

Fig. 3. A petal.

Fig. 4. A stamen a little magnified.

Fig. 5. Style and stigmas magnified. 
PI.TVI.

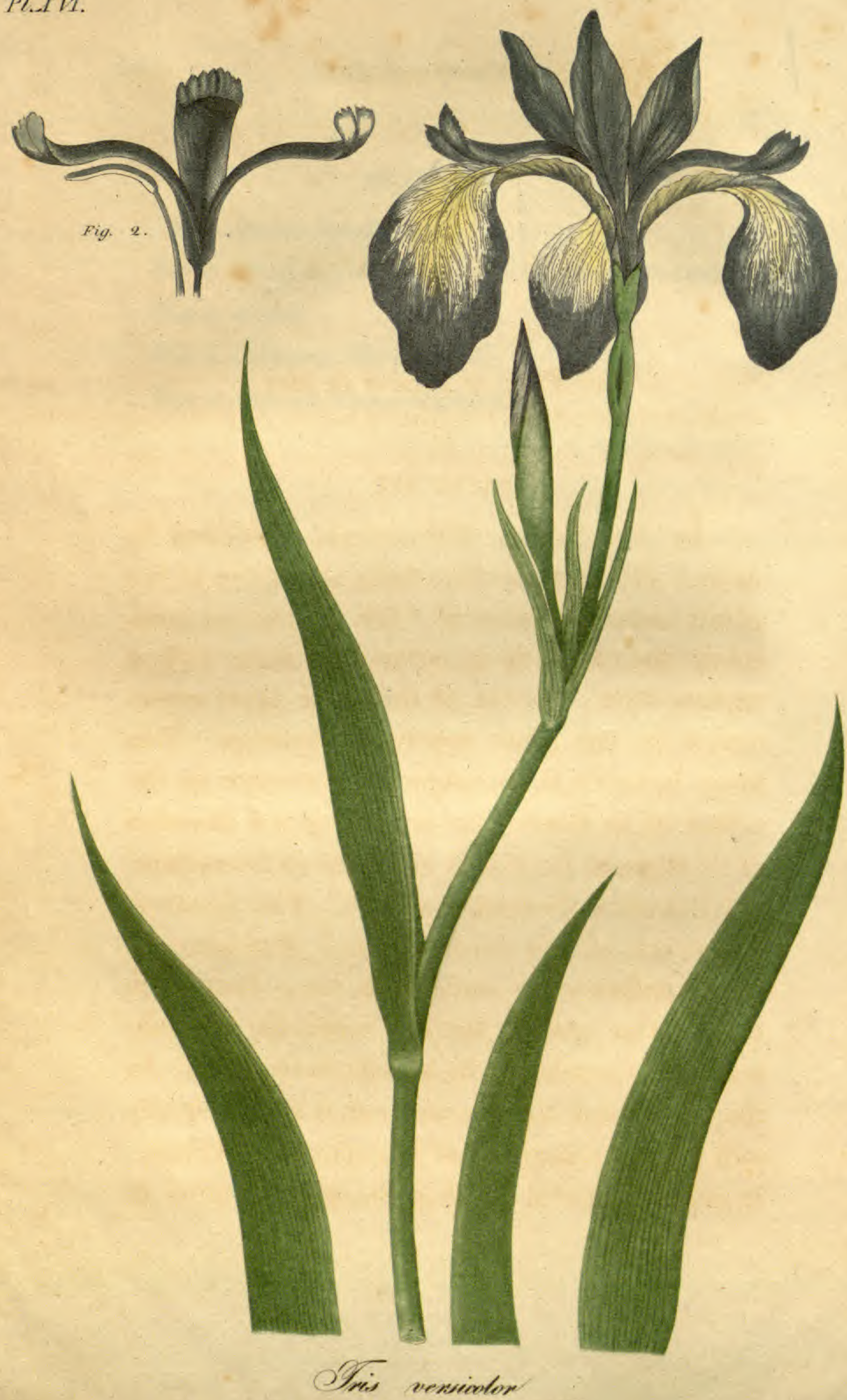




\title{
IRIS VERSICOLOR.
}

\author{
Blue Flag, or Flower de luce.

PLATE XVI.

IN the Hortus Elthamensis, published by John J. Dillenius in 1732, there are figures of two plants under the name of "Iris Americana versicolor," the one with an entire, the other with a crenate style. To one of these, the plant represented in our plate apparently belongs. This plant however is so subject to variation in the colour of its flowers, the crenatures and direction of its stigmas, \&c. that it has received from different botanists dissimilar names. The Linnæan characters of Iris versicolor and Virginica are hardly sufficient to distinguish them from each other. Our plant is the Iris versicolor of Muhlenburgh's catalogue, by his own declaration. In the character of its stem however, it agrees equally well with Iris virginica of Linnæus and Michaux. It may be doubted whether the plant figured in 
the Botanical Magazine, $t .703$, is more than a variety of this species. The characters taken from the comparative length of the stem and leaves, of the inner petals and stigmas, and the direction of the stem and of the stigmas; are all subject to variation. Michaux, Elliott and Pursh make the Virginica synonymous with Iris hexagona of Walter, which seems permanently distinguished by the deep furrows in the angles of its capsule.

The Iris versicolor is found throughout the United States in the borders of swamps and in wet meadows, of which it forms a principal ornament in the month of June. No race of vegetables can be better marked than the elegant genus to which this plant belongs. They are essentially distinguished by a corolla, parted into six segments or petals, of which three are reflexed and three are erect. The stigmas resembling petals. The species in our plate has ensiform leaves, its stem acute on one side, its capsules oblong, three sided, with obtuse angles.

Class Triandria,-Order Monogynia.-Natural orders, Ensato, Lin. Irides, Juss. Prdaceac. Sear.

The root is fleshy, horizontal, sending down a multitude of fibres. Stem two or three feet high, round on one side, acute on the other, frequently branched, and bearing from two to six flowers. 
Leaves sword shaped, striated, sheathing at base. Bractes becoming scarious. Peduncles of various length, flattened on the inside. Germ three cornered, with flat sides and obtuse angles. Outer petals of the flower spatulate, beardless, the border purple, the claw variegated with green, yellow and white, and veined with purple. Inner petals erect, varying in shape from spatulate to lanceolate, usually paler than the outer, entire or emarginate. Style short, concealed; stigmas three, petal-form, purple or violet, resting on the outer petals, their extremeties bifid, crenate, and more or less reflexed; their lower lip short. Stamens concealed under the stigmas, with oblong-linear anthers. Capsule three celled, three valved; when ripe, oblong, turgid, three sided, with roundish angles. Seeds numerous, flat.

The young leaves of this and some other species of Iris, afford an excellent view of the spiral filament, which lines the sap vessels of the leaf. If a leaf, which has just emerged from the ground, be carefully broken across, and the segments gradually drawn asunder, these fine filaments will unroll themselves, and their spiral structure become very obvious to the microseope.

The root of the Iris versicolor has a nauseous taste, and when swallowed or held in the mouth, 
even in small quantities, it leaves behind a powerful sense of heat and acrimony in the fauces. Its most active chemical constituent appears to be a resin, which separates in the form of a white precipitate, when water is added to the alcoholic solution. The decoction suffers little or no change with alcohol, gelatin or salts of iron. Muriate of tin affects it slightly, the nitrate of mercury more abundantly. Its taste is much weaker than that of the tincture. Water distilled from the root has a highly nauseous taste and odour.

The root of the Iris versicolor given medicinally is an active cathartic. Mr. William Bartram, in his travels in Georgia and Florida, informs us, that on his arrival at Ottasse, an Indian town on the Tallapoose, he found the natives " fasting, taking medicine, and praying, to avert a grevious calamity of sickness which had lately afflicted them, and laid in the grave abundance of their citizens. The first seven or eight days, during which time they eat or drink nothing, but a meagre gruel made of a little corn-flour and water; taking at the same time, by way of medicine or physic, a strong decoction of the roots of the Iris versicolor, which is a powerful cathartic. They hold this root in high estimation, and every town cultivates a little plantation of it, having a large artificial 
pond just without the town, planted and almost overgrown with it."

Having myself formerly made use of this root in dispensary practice, I can bear testimony to its efficacy as a medicine, though not altogether to its convenience. A small quantity of the recent root, or a few grains of the root newly dried, are generally certain and active in their operation on the bowels. They are however apt to occasion a distressing nausea like sea sickness, with a prostration of strength of some hours' continuance; so that I think the plant will not be like to come into favor as a cathartic, at least when better ones are at hand. The activity of this article is diminished by age.

The stimulating properties of the Iris render it capable of exciting many of the secretions, as well as excretions. But I know of no purpose for which it seems better calculated, than that of a diuretic. The late Dr. Macbride of Carolina assured me, that he had found great benefit in dropsical affections from a decoction of the roots of this plant in combination with those of Eryngium yuccifolium. In consequence of his recommendation, I administered the tincture of the Iris in small doses to several persons affected with anasarca and with hydrothorax. It was evidently of 
service to a majority of those who took it, for a certain time. That it did not always cure the disease, is a reproach which it must divide with diuretic remedies of much older celebrity.

The Iris gracilis, a species described in the Florula Bostoniensis, the Iris pseudacorus of Europe, and several others of the genus, appear to possess properties very similar to those of the plant described.

\section{BOTANICAL REFERENCES.}

Iris versicolor, Lin. $S p$. pl.-Dinuenius, Elth. $t$. 155.Curtis, Bot. Mag. t. 21, a variety.-Pursh, i. 29.-Euhrotr, Car. i. 45. WALTER, Car. 67.

\section{MEDICAL REFERENCES.}

Bartray, travels, 454, Lond. edit.-Cuther, Mem. Amer. Acad. 405-6.-M MCBRIDE, in Elliott's Car. i, 45.

\section{PLATE XVI.}

Fig. 1. Iris versicolor.

Fig. 2. Style and stigmas with a stamen. 


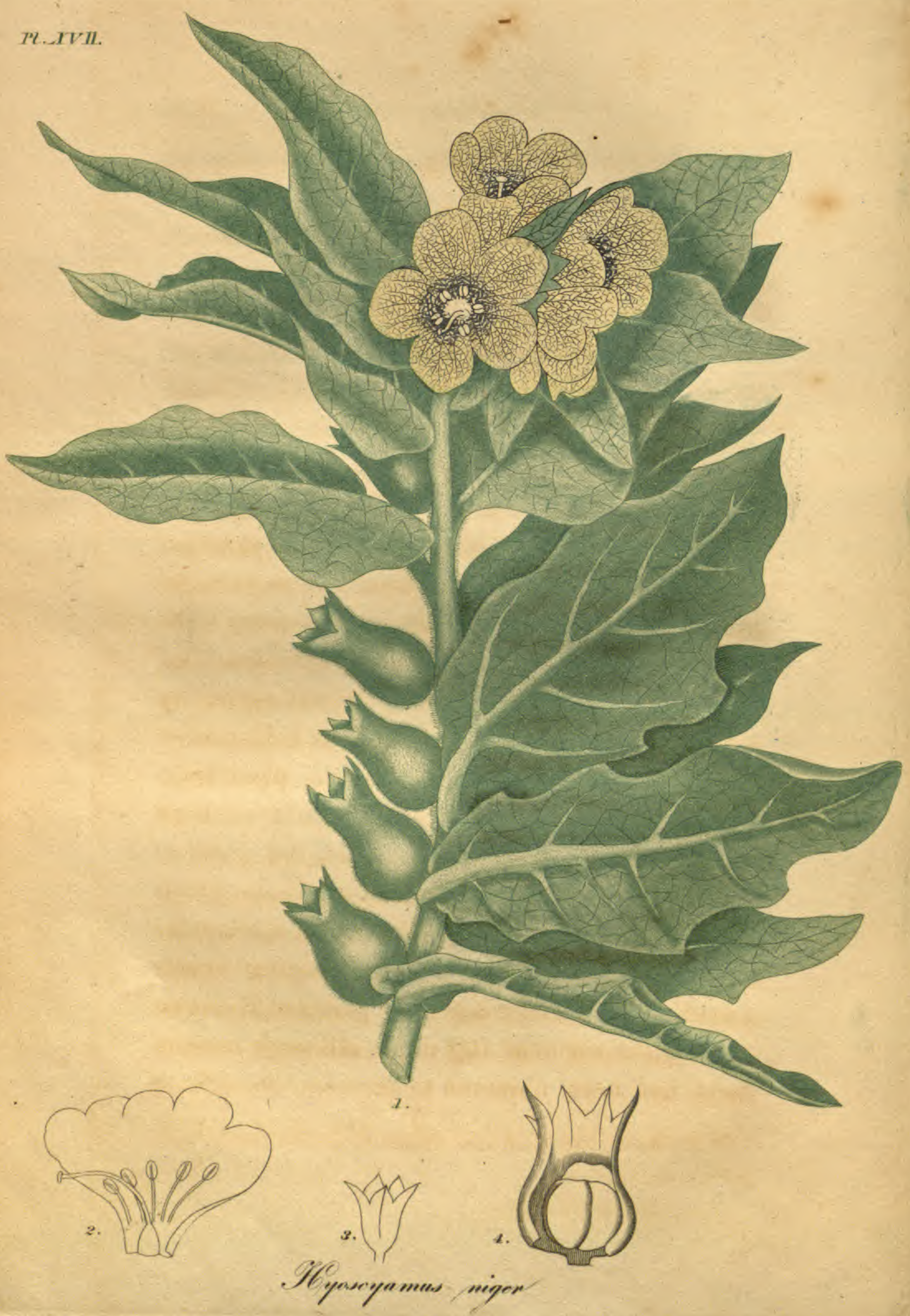




\title{
HYOSCYAMUS NIGER.
}

\author{
Henbane.
}

\section{$=$ \\ PL.ATE XVII,*}

Thene is little doubt that the Hyoscyamus of this country is an imported plant. It is yet rare in most parts of the country, and appears to be strictly limited to the bounds of cultivation. Its seeds are very tenacious of life, and will spring up under favourable circumstances, after having been dormant for a long time. Hence the plant occasionally appears in old grounds which have been newly disturbed, as in grave yards, old gardens and cellars. About ten years since, a drain, which intersects the common in Boston, was opened for the purpose of repairs. In the following season a distinct row of very luxuriant plants of Henbane covered the whole of this drain, although none of them had been observed to grow in the vicinity

* For the drawing which accompanies this article, I am indebted to Dr. S. Bass of Salem. 
the preceding year. The seeds, which produced these plants, had probably been buried for more than fifteen years.

This species, together with others of its genus, was well known to the ancients under the same name which it now bears. Its medicinal and deleterious properties were also understood by them.

In modern arrangements the Hyoscyamus in common with Datura, Atropa and other injurious vegetables of its kindred, is found in the class and order Pentandria Monogynia, and the natural order Lurida. Its Jussieuean order is Solanea. df
In this genus the corolla is funnel shaped and obtuse, the stamens inclined, the capsule two celled and covered with a lid.

The present species has the lower leaves sinuated and clasping, and the flowers sessile. It is biennial and flowers in June and July.

The whole herb has a glaucous or sea green colour, is hairy and viscid, and emits a rank, offensive smell. The stalk is one or two feet high, round, branching and rigid. The first leaves spread upon the ground, and have some resemblance to a young thistle. They are large, oblong, frequently contorted, clasping, cut into 
acute lobes, and pointed ; the upper ones generally entire.

The flowers form a revolute, one sided spike at the end of the stem or branch, leaving, as they fall off, a straight row of capsules. The calyx has five short acute segments. The corolla is funnel shaped, irregular, with five spreading, obtuse segments, of a pale yellow or straw colour, with a beautiful net work of purple veins. Stamens inserted in the tube of the corolla, with large oblong anthers. Style slender, longer than the stamens, declined, with an obtuse stigma. Capsule two celled, roundish, covered with a lid, and invested with the persistent calyx, the segments of which extend beyond the calyx, and become rigid and prickly. The seeds are numerous, small, unequal, brownish, and are discharged by the horizontal separation of the lid.

From such chemical experiments as I have made with the dried leaves of the Hyoscyamus, I am inclined to believe, that their chief soluble portion is a variety of extractive matter. The watery and alcoholic solutions do not disturb each other, and the usual tests of tannin produce inconsiderable, or no alteration in either. Of various metallic salts which affected the solutions, the 
nitrate of mercury gave the largest precipitate in my experiments.

The Hyoscyamus has long been known as a narcotic poison. This character it uniformly exerts in regard to mankind, although many brute animals are exempt from its influence.* Dioscorides speaks of it as producing drowsiness and delirium.

* Horses, goats, sheep and swine are said to eat it without injury. Brute animals are frequently less susceptible of the influence of poisons than mankind. In the experiments which have been made on them to test the effect of doubtful medicines, the positive evidences of activity which they furnish, are in general more to be depended on, than the negative. That is, if an animal suffers from the action of any substance, a man would be like to suffer somewhat in the same way. Yet if the animal escapes with impunity, it does not follow that the man would be equally fortunate. There is scarcely any narcotic plant which is not devoured by some species of quadruped. Professor Pallas has stated, that the hedgehog can devour Cantharides by hundreds without inconvenience, whereas one of these insects may occasion serious trouble to a man. The following case happened under my own observation. A large eagle, (Falco ossifragus,) intended for a cabinet of natural history, was subjected to a variety of experiments, with a view to destroy him without injuring his plumage. A number of mineral poisons were successively given him without effect, even in large doses. At length a drachm of corrosive sublimate of mercury was inclosed in a small fish and given him to eat. After swallowing the whole of this, he continued, to appearance, perfectly well and free from inconvenience. The next day an equal quantity of arsenic was given him without any better success. So that in the end, the refractory bird was obliged to be put to death by mechanical means. 
The instances recorded of deleterious consequences, ensuing from the Hyoscyamus incautiously taken, are exceedingly numerous. In a number of cases the roots have been introduced by mistake among culinary vegetables, and have occasioned alarming symptoms in whole families at once. In a case cited by Wepfer, the monks of a whole monastery, in consequence of some roots being boiled among those of chicory with their food, were seized with raving delirium, accompanied by intense thirst, impaired vision and other violent affections. Dr. Patouillat has recorded in the Philosophical Transactions, vol. 40, the case of nine persons, who were affected with loss of speech, convulsions, and at length with violent delirium. These symptoms subsided on the subsequent day, when it was found that some roots of Henbane had been dug up in the garden the preceding day by mistake for parsnips, and boiled in the soup on which the family had dined. Sir Hans Sloane, in the same Transactions for 1733, has given an instance of effects equally dangerous, occurring in some children who ate the capsules of this plant, supposing them to be filberds. Even the odour of this noxious vegetable seems capable of exciting its characteristic effects. In a case cited by Murray from the 
Gazette de Sante of $1773-4$, some servants who slept in a barn, where the Henbane had been scattered for a defense against rats, awoke, with head-ach, dizziness and vomiting.

In instances where death has ensued from swallowing this plant, the stomach has been found to exhibit marks of inflammation, and dark or gangrenous spots.

The principal use which is made of Hyoseyamus in medicine, is as a substitute for opium, in cases where that article disagrees with the patient, or is contraindicated by particular symptoms. It appears to be free from the constipating qualities of opium, and in some instances it is found to fulfil the indications which call for an anodyne and soporific remarkably well. Among medical writers who have spoken favourably of its operation are Dr. Whytt, who employed it in various nervous diseases, and Mr. Burns, author of different obstetric works, by whom it is recommended as preferable to opium in certain puerperal complaints. Mr. Benjamin Bell states, that he found great advantage from its use in troublesome cases of chordee, after opium had failed to give relief.

It must be acknowledged however, that Hyoscyamus is far less uniform and equal in its opera- 
tion than opium, and that although in some constitutions it mitigates pain, quiets irritation, and procures sleep; yet in others it produces unpleasant nausea, confusion of ideas, head-ach, and sleep which is laborious and unrefreshing. It is rather a secondary medicine, to be resorted to after the failure of opium, than one which we may confidently apply to at first, with reliance on its anodyne effects.

The Henbane was found efficacious in the disease of colica pictorum by Stoll and several others. Its external application in the form of a cataplasm of the bruised leaves has given relief in various tumors and painful affections.

For internal use the extract should be prepared in the same way as that of stramonium. From one to three grains of this extract is a suitable commencing dose, which may be gradually increased until its effects are perceived.

\section{BOTANICAL REFERENCES.}

Hyoscyamus niger, Linn. $S p$. pl.-WoodvmLE, i. $t$. 52.Sмiтн, Engl. Bot. t. 591.-PuRsh, i. 141.-Hyoscyamus flavus, Fuchsius, Hist. 791.-Hyoscyamus vulgaris, BavHIN, J. iii, 627.

\section{MEDICAL REFERENCES.}

Ston, ratio med. iii. 13, 423.-Cumen, Mat. Med. ii. 271. Fothergin, Med. Soc. Lond. i. S10.-Hoмe, clinical exp'ts, 22 
197.-Withering, Med. Comment. Dec. II, vi. 367.-KingIAKe, Lond. Med. and Phys. Journal, v. 438.-Brown, ditto, iii. 406.-Murray. App. Med. i. 655, \&c. \&c.

\section{PLATE XVII.}

Fig. 1. Hyoscyamus niger.

Fig. 2. Corolla laid open.

Fig. 3. Calyx.

Fig. 4. Calyx of the fruit laid open to shero the capsule within it. 


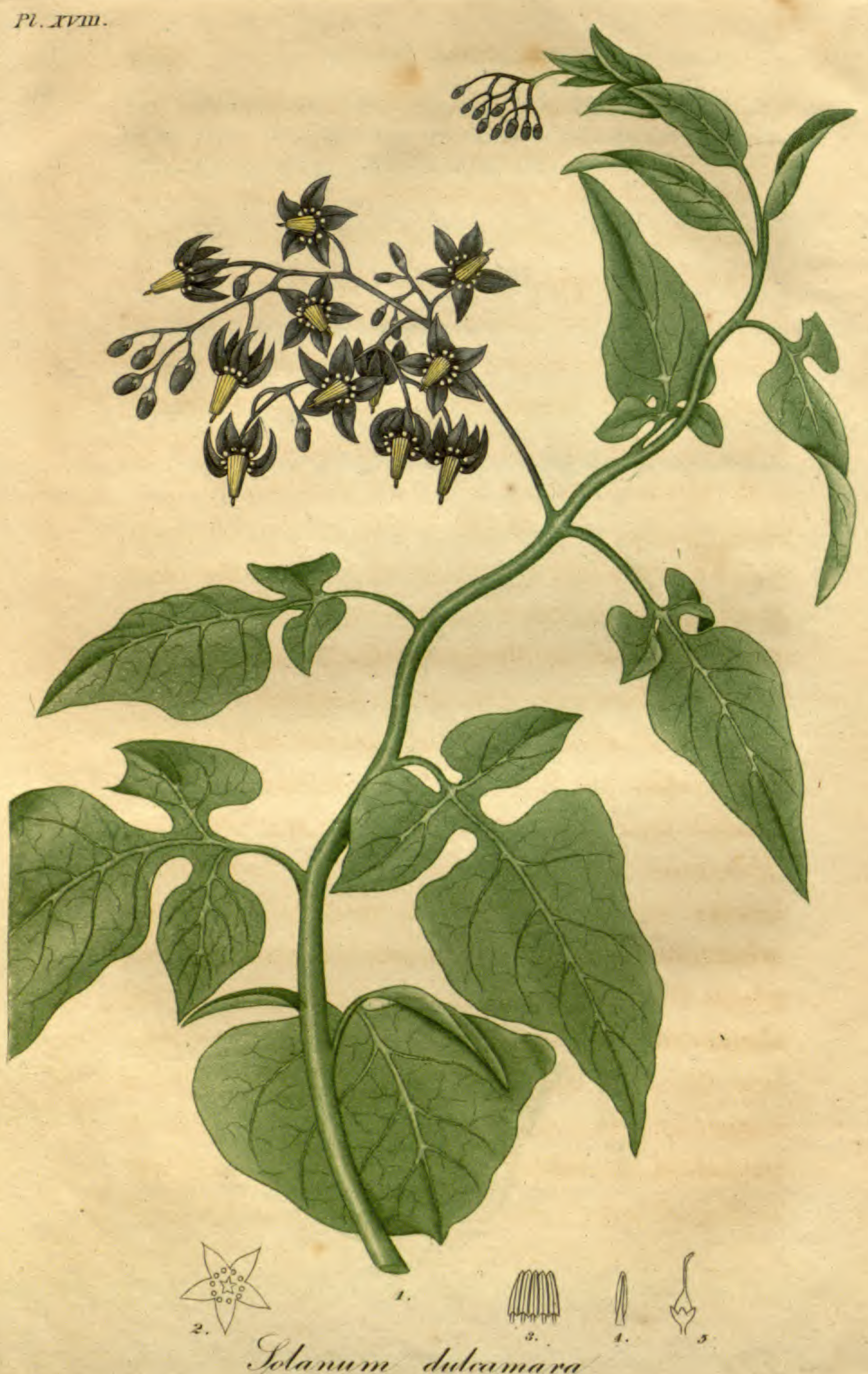




\section{SOLANUM DULCAMARA.}

Bitter sweet.

PLATE XVIIT.

$W_{\text {hether the plant represented in our plate }}$ is originally of American growth, or has been introduced since the discovery of this continent, it is now difficult to say. It is certainly a hardy vegetable, and although its natural soil is at the water side, yet it easily becomes habituated to shady, fertile ground of almost any elevation. The most luxuriant specimens are found about brooks and ditches and in sheltered situations, where the roots have free access to water. In these places the stalks frequently extend some way on the surface, sending down a multitude of radicles into the mud below. When the plant grows in higher ground and more exposed to the light, its growth is restricted, and the flowers are less brilliant in colour. 
The names of Bitter sweet and Woody nightshade are the most frequent English appellations of this vegetable. The former of these is also applied to the Celastrus scandens, a very different plant. The frequent changes which always take place in the application of vulgar names, renders a reliance on them unsafe, and indeed makes it useless to collect or preserve more than a few of the principal ones.

The genus Solanum is remarkable for the great variety and almost opposite character which takes place among its species. The common Potatoe, the Egg plant, the Tomato, the Jerusalem cherry, and the Black nightshade, are all species of this multiform genus. The common character which binds them together, consists in a rotate corolla; the anthers cohering, with a double opening at top; the berry two celled. The species Dulcamara is distinguished from others by its stem, which is shrubby; unarmed and flexuous; its leaves auriculated; and its panicles resembling cymes.

Class Pentandria,-Order Monogynia,-Natu-

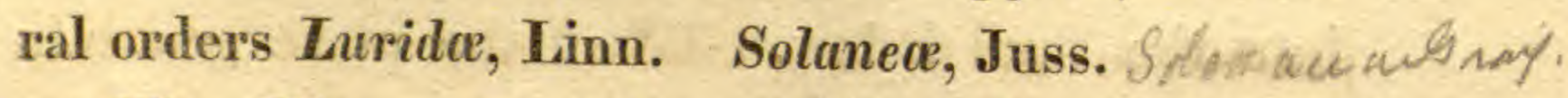

The Bitter sweet is entitled to the character of a vine rather than shrub. The stem is woody, slender, climbing in large plants to the height of 
five or six feet. Leaves petioled, ovate, acute, entire, furnished at the base with two appendages, which give them somewhat of a hastate form. The lower and upper leaves are frequently without these appendages. The flowers form a loose, nodding cluster or panicle, shaped like a cyme, and taking its origin opposite to a leaf. Calyx of five short, purplish, persistent segments. Corolla rotate, becoming reflexed as it grows old, divided into five acute segments, which are purple, and marked with two whitish dots at the base of each. The filaments are much shorter than the anthers, and inserted in the short tube of the corolla. Anthers yellow, erect, cohering; so as to form a conical tube around the style. Germ oval; style longer than the stamens; stigma simple. The berries are oval, of a bright scarlet colour, and continue to hang in bunches after the leaves have fallen.

The taste and smell of the Dulcamara are less nauseous than those of many other species of Solanum. Water seems a perfect solvent for its most sensible constituents. The chief soluble portion seems to be a kind of mucous extractive, which is taken up by both water and alcohol, though most by the former. The nitrate of mercury and muriate of tin, gave precipitates from 
both, though most from the water. The chemical evidences of astringency were very slight.

From the experiments of Hartmann and Kuhn, cited by Murray, we may infer that water is a better solvent for this plant than alcohol. An ounce of the twigs or stalks treated with alcohol afforded two drachms and two scruples of extract. The same quantity treated with water gave three drachms and thirty five grains.

The Solanum dulcamara has formerly received the commendations of many authors, some of whose names are of high authority in medicine. The diseases in which it has acquired confidence, are chronic rheumatism, gout, secondary syphilis, incipient phthisis, asthma, jaundice. But whatever may be its efficacy in these complaints, it has in modern practice given place to more active medicines. Its most permanent and merited reputation at the present day, is derived from its application to external complaints, and particularly to cutaneous diseases. In dissertations upon the properties of this plant by Linnæus and by Carrere, its use is highly commended in herpes, in scabies, and in some of the secondary forms of syphilis. Professor Murray has added his own testimony to that of these writers, and speaks de- 
cisively of his success with it in cutaneous diseases of an inveterate character.

In the more recent and splendid works of Willan and Bateman on Diseases of the Skin, we find some important testimony of the efficacy of the Dulcamara in cutaneous affections. The former of these authors has inserted in his work a letter of Dr. Crichton, physician to the Westminster hospital, who had employed the article for a considerable number of years. This gentleman states, that out of twenty three cases of Lepra Grecorum, in which he had used it, two only had resisted its action. He does not assert that it is equally efficacious in other cutaneous diseases, although it had appeared to him to do good in psoriasis and pityriasis. His mode of employing it was as follows :

Take of stalks of Dulcamara, one ounce ; water, a pound and a half; boil to a pound, and strain when cold.

Of this decoction the patient took two ounces at first, morning, noon and night, but the quantity was afterwards increased, until it amounted to a pint per day. At the same time the skin was ordered to be washed with a stronger decoction, which proved an auxiliary to the cure. Dr. Crichton found that in delicate people and hyster- 
ical women, it often produced syncope and slight palpitation of the heart, now and then nausea and giddiness. But if the dose was diminished, or any aromatic tincture added, it ceased to produce uneasy symptoms. The good effects of the remedy were seldom perceived until after the first eight days.

Dr. Bateman considers, that "one of the most effectual remedies for lepra under all its varieties is the decoction of the leaves and twigs of the Solanum dulcamara." He administers it in the same way with that just described. "When," says he, "there is a degree of torpor in the superficial vessels, the same decoction made with a larger proportion of the shrub, is advantageously employed as a lotion; but if there is any inflammatory disposition, this and every other external stimulus must be prohibited."

I have employed the Bitter sweet, both in substance and in decoction in a number of cutaneous affections. It appears to be a valuable auxiliary to mereury in the treatment of syphilitic eruptions. I have also known herpetic eruptions to yield to its internal and external use. The American plant however, when gathered in full vigour, does not set easily on the stomach in large doses. I have known vomiting produced by a few grains 
of the powdered leaves, and by a small cup of the decoction. The strength of the plant seems to vary in some degree with the time of gathering, and mode of preserving. Dr. Cullen found different parcels of the article to exhibit very different degrees of strength. Writers are not agreed as to its immediate effects on the head and stomach, probably from the different age and condition of the medicine employed by them. From my own observation I am induced to consider the appearance of slight narcotic symptoms, as an evidence of the goodness of the medicine, and as a criterion for regulating the dose. The formula of Dr. Crichton for the decoction appears to be a good one, but in the case of delicate constitutions, the commencing dose should not exceed an ounce, which may be afterwards increased according to circumstances. The addition of a little cinnamon renders the decoction less apt to offend the stomach.

\section{BOTANICAL REFERENCES.}

Solanum dulcamara, Linnzes, Sp. pl.-Woopvmue, $t$. ss.Sмiтn, Engl. Bot. t. 565.-Pursh, i. 156.-Solanum scandens, seu dulcamara.-Tournefort, Paris, 43.-Glycypicros sive amaradulcis, J. B.UHIv, ii. 109. 


\section{MEDICAL REFERENCES:}

Booerhante, Hist. hort. L. B. 506.-Linnaus, Amoen. Acad. iv. 39, and viii. 62.-Murrax, App. med. 603.-C CARRERE, sur la Douce-amere, 1780, and in Med. and Phys. Journal, i. 307.Culuen, Mat. Med. ii. 554-WILLAN, on Cutaneous diseases, 145. -Bateman, on ditto, 35.-ORfHA, des poisons, 192:

\section{PLATE XVIII.}

Fig. 1. Solanum dulcamara.

Fig. 2. Corolla.

Fig. 3. Tube of anthers laid open.

Fig. 4. Stamen.

Fig. 5. Calyx and pistil. 


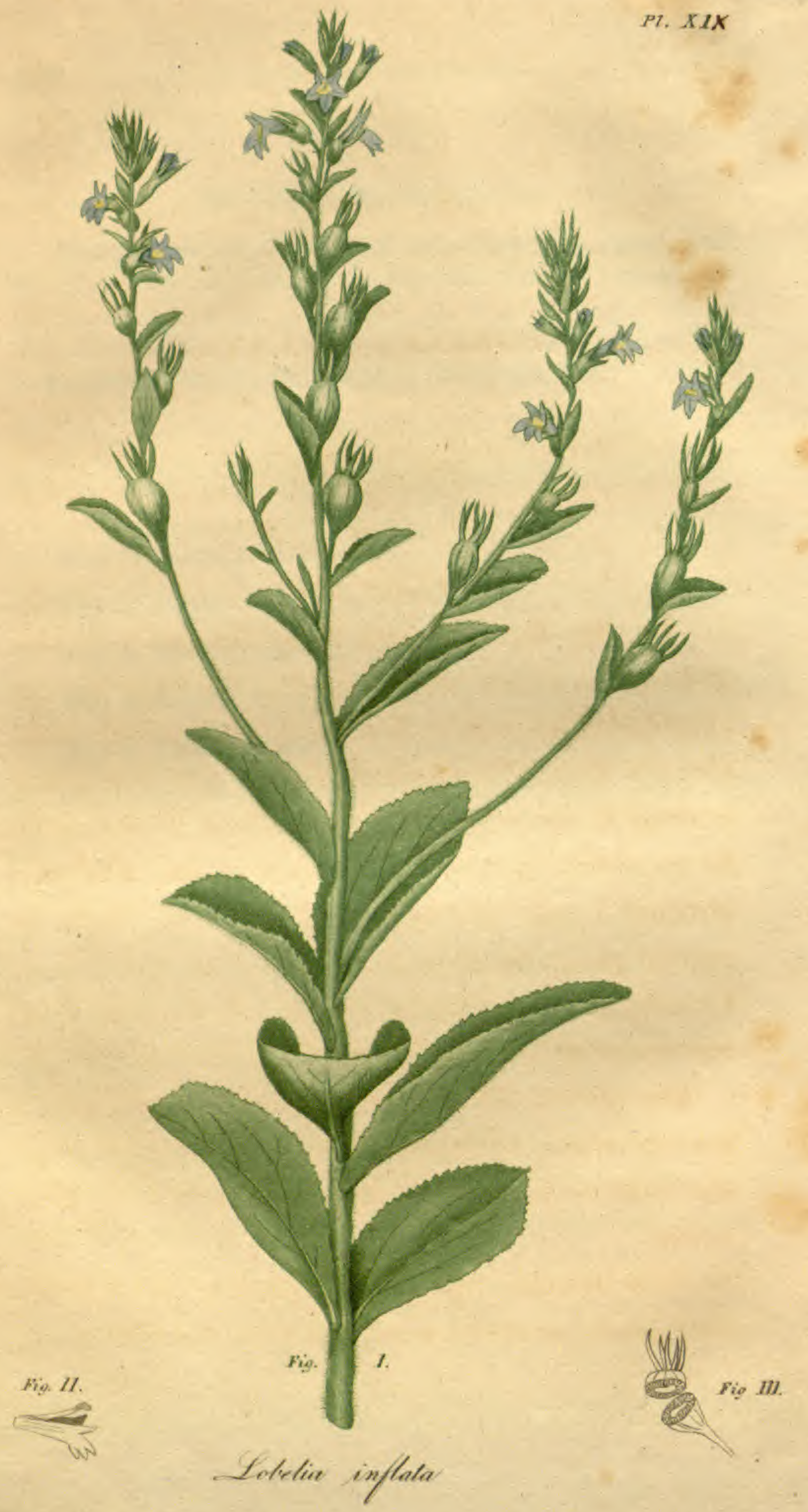




\title{
LOBELIA INFLATA.
}

\author{
Indian tobacco.
}

\section{$=$ \\ PLATE XIX.}

$I_{N}$ the United States there are many species of Lobelia, which are interesting for their beauty, singularity or use. We have few plants more elegant than the cardinal flower, and few more curious in structure than the Lobelia Dortmanna. In medicinal powers, the subject of this article is entitled to take precedence of the rest. It is an annual plant, found in fields and road sides, from Canada to the southern states. It flowers from midsummer until the arrival of frosts.

The genus Lobelia has a five cleft calyx; a monopetalous, irregular corolla, with a cleft tube; the anthers cohering; the capsule two or three celled.

The species inflata is branching and hairy, with ovate, serrate leaves, and turgid capsules. 
The connexion of the anthers into a tube has caused some ambiguity and difference of opinion, as to the place which this genus should occupy, in the Linnæan system. Linnæus placed it in his order Monogamia of the class Syngenesia. Most of our late botanists have very properly removed the plants of this order from the compound flowers, with which they have no natural affinity, to Pentandria, which place their number of stamens authorizes them to occupy. Pursh has placed the Lobelias under Monadelphia. The Natural order which contains them is the Campanacee of Linneus and Jussieu. Lobliwew 15 ,
The Lobelia inflata varies in height from six inches to two or three feet. The small plants are nearly simple, the large ones much branched. Root fibrous. Stem erect, in the full sized plant much branched, angular, very hairy. Leaves scattered, sessile, oval, serrate, veiny and hairy. Flowers in spikes or racemes, pedunculated, each one in the axil of a small leaf. Segments of the calyx linear, acute, standing on the germ, which is oval and striated. Corolla bluish purple, the tube prismatic and cleft above, the segments spreading, acute, the two upper ones lanceolate, the three lower ones oval. Anthers collected into an oblong, curved body, purple; filaments 
white. Style filiform; stigma curved and inclosed by the anthers. Capsules two celled, turgid, oval, compressed, ten angled, covered with the calyx. Seeds numerous, small, oblong, brown.

The Lobelia inflata when broken, emits a milky juice. When chewed, it communicates to the mouth a burning, acrimonious sensation, not unlike the taste of green tobacco. It exhibits the following noticeable ingredients upon chemical examination. 1. An acrid principle. This is evident to the taste in the tincture, decoction, and distilled water. 2. Caoutchouc. Sulphuric ether dissolves more of the plant than alcohol, and acquires a higher colour. The solution in alcohol is scarcely rendered turbid by water, that in ether is disturbed by alcohol, and grows thick as the ether evaporates. 3. Extractive. No gummy or astringent qualities were manifested in my experiments.

The great acrimony of the leaves and capsules, combined with a nareotic property, appears to be the foundation of their medicinal power. Dr. Cutler informs us, that if the leaves be held for some time in the mouth, they produce giddiness and pain in the heatl, with a trembling agitation of the whole body, and at length bring on nausea and vomiting. These effects are analagous to 
those, which the chewing or smoking of tobaces occasions in persons unaccustomed to its use.

When swallowed in substance, it excites very speedy vomiting, accompanied with distressing and long continued sickness, and even with dangerous symptoms, if the dose be large. A melancholy instance of death, occasioned by the use of this plant, in the hands of a quack, is detailed in the sixth volume of the Massachusetts Reports, in the trial of Samuel Thomson, an empiric practising in Beverly, for the murder of Ezra Lovett. In this trial it appeared, that the patient, being confined by a cold, sent for the pretended physician, who gave him three powders of Lobelia in the course of half an hour, each of which vomited him violently, and left him in a great perspiration during the night. The next day two more powders were administered, each of which operated by vomiting and occasioned great distress. In like manner two other powders were given the subsequent day, leaving the patient in a state of great prostration. Several days after this, the physician came again, and finding his patient still worse, administered several more powders, which occasioned great disfress, and at length ceased to operate. Finding that the stomach was not sensible to the emetic effect of the Lobelia, 
the physician repeated the dose, and when the patient complained of great distress at the breast and said he was dying, the doctor assured him the medicine would soon get down, or operate as a cathartic. However, on the same evening, the patient lost his reason and became convulsed, so that two men were required to hold him. To relieve which, the doctor forced down two more of his powders, and the patient, as was to be expected, grew worse, and continued so until he expired.

The doctor, who had thus terminated the disease and the patient at once, was arrested and put upon trial for murder; but the homicide proving a legitimate one from the want of sufficient evidence of malice propense, he was acquitted and set at liberty.

From the violence of its effects, and the distressing nausea which it occasions, it is probable that the Lobelia will never come into use for the common purposes of an emetic, while other emetics can be obtained. It has however been found to exert a beneficial influence on particular diseases, and on this account is entitled to a place in the Materia Medica. Dr. Cutler, and a number of physicians in Essex county and elsewhere, have found benefit from its use in asthma, some in doses of a table spoonful of the saturated tincture, 
others in doses of a teaspoonful. Indeed the former dose appears to be a very large one, and greater than most stomachs would bear with impunity. I have tried this medicine in several cases of asthma with some advantage. It has not however in general succeeded in affording relief of the paroxysm, until full vomiting was produced, which effect, with me, has happened after taking one or two teaspoonfuls.

A communication from Dr. Cutler, on the operation of this plant, is inserted in Dr. Thacher's Dispensatory. The venerable writer having himself suffered from asthma for ten years, had, during the paroxysms, resorted to many medicines for relief, without experiencing much benefit from any. He was at length induced to make trial of a tincture, prepared by himself from the Lobelia inflata. "In a paroxysm," says he, "which perhaps was as severe as I had ever experienced; the difficulty of breathing extreme, and after it had continued for a considerable time, I took a table spoonful. In three or four minutes my breathing was as fiee as it ever was, but I felt no nausea at the stomach. In ten minutes I took another spoonful, which occasioned sickness. After ten minutes I took a third, which produced sensible effects upon the coats of the stomach, and a 
very little moderate puking; and a kind of prickly sensation through the whole system, even to the extremities of the fingers and toes. But all these sensations very soon subsided, and a vigour seemed to be restored to the constitution, which I had not experienced for years. I have not since had a paroxysm, and only a few times some small symptoms of asthma. Besides the violent attacks, I had scarcely passed a night without more or less of it, and often so as not to be able to lie in bed. Since that time I have enjoyed as good health, as perhaps before the first attack."

Dr. Cutler considers his disease to be what Dr. Bree in his "Practical inquiries on disordered respiration" calls the first species, "an asthma from pulmonic irritation of effused serum."

Dr. Randall informs me, that he has given the Lobelia to many persons of difierent ages suffering from asthma and catarrh, and with considerable variation in the form and degree of the dose. In asthma he finds it as successful as any article he has tried. When given in doses of a drachm of the saturated tincture, and two or three times repeated at convenient intervals ; also in the form of other preparations of similar strength, he has found it usually to remove the paroxysm in a short time, and to restore the patient to qui- 
etude and ease. In catarrh, when given in small doses and frequently repeated, it has operated as a sure and speedy expectorant, producing effects in their most important character, very similar to those of antimony and squills. Dr. Randall has not observed any narcotic effect to ensue from moderate doses, nor found it to produce irritation' of the coats of the bladder, as has been suggested by some practitioners. In his hands it has not produced any more unpleasant consequence than frequent nausea, and occasional emesis, with a copious flow from the glands of the mouth.

Dr. Bradstreet of Newburyport acquaints me, that besides asthmatic cases, he has given the saturated tincture in two or three instances of dyspepsia, also in some cases of a rheumatic nature with beneficial consequences.

He considers its sensible effects to be very like those of common tobaceo, but its medicinal action more speedy and diffusible, and of shorter duration. He thinks that it affects those accustomed to the use of tobaceo as readily as others.

The Lobelia has been recommended as a remedy in hooping cough and croup. In the former of these complaints, I can say nothing of its use from experience, but in the latter disease I am 
persuaded, it affords no benefit, having seen it largely tried by different practitioners in a number of fatal cases, where it only produced a distressing nausea, without, in any degree, facilitating the respiration, or relieving the disease.

The active properties of the Lobelia are readily extracted both by water and alcohol. The tineture however is most easily kept, and is the most convenient form for exhibition. The Essex district medical society have recommended a formula for this composition, which directs two ounces of the dried plant to be digested in a pint of diluted alcohol. Of this tincture, a teaspoonful given to an adult, will generally produce nausea, and sometimes vomiting. In certain instances however, much larger doses have been given, without producing any other effect than a flow of saliva.

\section{BOTANICAL REFERENCES.}

Lobelia inflata, Lin. Sp. pl.-Acr. Upsal. 1741, p. 23, t. 1.Gronovius, Virg. 134.-Wmu. Sp. pl. i. 946.-Mrchaex, ii. 142.-Punsh, ii. 448.

\section{MEDICAL REFERENCES.}

Cutrer, Mem. Amer. Acad. i. 484.-Schöp, 128-BART. Col. 36, 56.-THacher, Disp. 267.-Massachusetts Reports, vol. vi. 


\section{PLATE XIX.}

Fig. 1. Lobelia inflata.

Fig. 2. Corolla with the stamens projecting from the cleft in the upper side.

Fig. 3. Capsule cut across. 


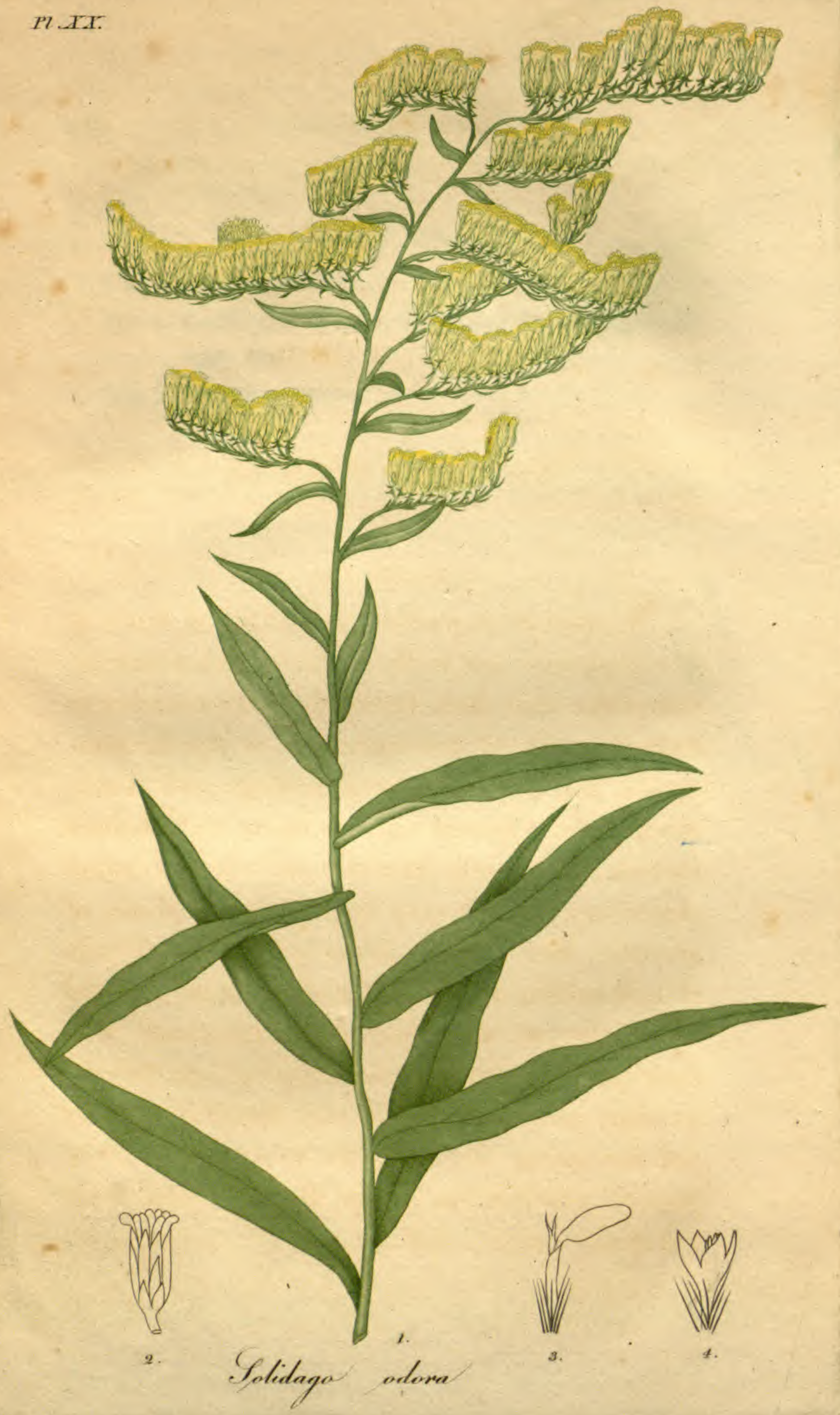




\section{SOLIDAGO ODORA.}

\section{Sweet scented Golden rod.}

\section{TE $X X$.}

No part of vegetation in the United States is so conspicuous and gaudy in the autumnal months, and at the same time furnishes to the botanist so difficult a task of discrimination, as the multitudinous and Protean genera Solidago and Aster. Each of these genera contains many well defined species, sufficiently marked by their external characters, sensible qualities, habits and places of growth. But between them, is a great multitude of subspecies, liable to variation from external circumstances, changing their appearance with their places of growth, and running together by so many points of resemblance, that it is a labour yet remaining for botanists to separate those species which are in nature distinct, from those which are varieties only. 
The genus Solidago is characterized by a naked receptacle, the doron simple, rays of the corolla about five, scales of the calyx imbricated and close. It is a very natural genus, easily distinguished at sight by its crowded tufts of compound flowers, which are almost always of a deep golden yellow.*

The species odora has its stem nearly smooth, leaves linear-lanceolate, entire, smooth, with a rough margin, and covered with pellucid dots. Racemes panicled, one sided.

Class Syngenesia, Order Superflua,-Natural orders Compositoe, Lin. Corymbiferce, Juss.

The sweet scented Golden rod grows in woods and fields throughout the United States, and flowers in September. It has a smooth appearance, and is among the smaller species of its family. The root is woody, much branched and creeping. Stem slender, from two to three feet high, smooth or slightly pubescent below, pubescent at top. The leaves are linear-lanceolate, closely sessile, broad at baze, entire, acute, with only the midrib distinct, rough at the margin but otherwise smooth, and covered with pellucid dots, like $\mathrm{Hy}_{\text {- }}$ pericum perforatum. The flowers grow in a compound, panieled raceme, with each of its branches

* The only exception which I now recollect is Solidago bicolor ${ }_{2}$ whose ray is white. 
supported by a small leaf. These branches or peduncles are very slender and rigid, each giving off a row of ascending, downy pedicels, with small, linear bractes at their bases. Scales of the calyx oblong, acute, smooth, or slightly pubescent, the lower ones shorter and closely imbricating the rest. Florets of the ray few, with oblong, obtuse, ligules. Those of the dise funnel shaped, with acute segments. Down simple to the naked eye, feathery under the microscope. Seeds oblong.

This plant is the Solidago odora of Muhlenberg, and agrees with the character of Aiton. The Solidago odora of Michaux is possibly a different species. Willdenow's plant was undoubtedly different. The folia puncticulosa, which constitutes so distinet a mark in this species, I have not seen noticed by any botanist.

The leaves of the Solidago odora have a delightfully fragrant odour, partaking of that of anise and sassafras, but different from either. When subjected to distillation, a volatile oil, possessing the taste and aroma of the plant in a high degree, collects in the receiver. This oil apparently has its residence in the transparent cells, which constitute the dotting of the leaves, for the root is wholly destitute of the peculiar fragrance of the herb, and has rather a nauseous taste. This is contra- 
ry to the remark of Willdenow, who informs us that the root is the fragrant part possessing the scent of Geum urbanum.

As the volatile oil appears to possess all the medicinal value of this plant, I have not prosecuted its chemical investigation any farther.

The claims of the Solidago to stand as an article of the Materia Medica are of a humble, but not despicable kind. We import and consume many foreign drugs which possess no virtue beJond that of being aromatic, pleasant to the taste, gently stimulant, diaphoretic and carminative. All these properties the Golden rod seems fully to possess. An essence made by dissolving the essential oil in proof spirit, is used in the eastern states as a remedy in complaints, arising from flatulence, and as a vehicle for unpleasant medieines of various kinds. I have employed it to allay romiting, and to relieve spasmodic pains in the stomach of the milder kind, with satisfactory success. From its pleasant flavour, it serves to cover the taste of laudanum, eastor oil, and other medicines, whose disagreeable taste causes them to be rejected by delicate and irritable stomachs.

Mr. Pursh informs us, that this plant when dried, is used in some parts of the United States as an agreeable substitute for tea. He further states, 
that it has for some time been an article of exportation to China, where it fetches a high price.

\section{BOTANICAL REFERENCES.}

Solidago odora, Arton, Hort. Kew. iii. 214.-PURsh, ii. 539. - Virga Aurea Americana, Tarraconis facie et sapore, panicula speciosissima? Plukenet, alm. $389, t$. 116, $f .6$.

\section{PLATE XX.}

Fig. 1. Solida odora.

Fig. 2. A flower magnified.

Fig. 3. A floret of the ray.

Fig. 4. A floret of the disc. 


\section{NOTES.}

\section{$=$ \\ Note A.}

Most European writers seem to consider the Datura stramonium as a native of America. In Miller's Dictionary by Martyn, the editor says, "That it is a native of America, we have the most undoubted proofs, for in earth brought with plants from various parts of that extensive country, we are sure to have the Thorn apple come up. Kalm says, that it grows about all the villages, and that this and the Phytolacca are the worst weeds there. Our old writers call it Thorny Apples of Peru."

This evidence however is by no means sufficient. The plant appears in earth and ballast, carried from either continent alike. The name Apple of Peru has also been applied to Datura metel, a plant of Africa and the East Indies.

\section{Note $\boldsymbol{B}$.}

In the Catalogue of plants in the Botanic garden at Calcutta, published in 1814, a species is inserted by the name of Datura Tatula, said to be a native of the Cape of Good Hope. This is probably different from the Datura Tatula of Linnæus.

\section{Note $\boldsymbol{C}$.}

"The Jamestown weed, (which resembles the thorny apples of Peru, and I take it to be the plant so called,) is supposed to be one of the greatest coolers in the world. This being an early plant, was gathered very young for a boiled sallad, by some of the soldiers sent thither to quell the rebellion of Bacon; and some of them ate plentifully of it, the effect of which was a very 
pleasant comedy, for they turned natural fools upon it for several days. One would blow up a feather in the air, another would dart straws at it with much fury; another stark naked was sitting up in a corner like a monkey, grinning, and making mows at them; a fourth would fondly kiss and paw his companions, and sneer in their faces with a countenance more antic, than any in a Dutch droll. In this frantic condition they were confined, lest, in their folly, they should destroy themselves. A thousand simple tricks they played, and after eleven days returned to themselves again, not remembering any thing that had passed." Beverly's History of Virginia, p. 121.

\section{Note $\mathrm{D}$.}

"De Cuechyliztomatl, seu Tomatl sonalis.

Genus est Solani Tonchichi forma et viribus simile, sed foliis paulisper undulatis, et fructu acinoso racematimque dependente, \&c." Hernandez, ii. 12.

\section{Note $\boldsymbol{E}$.}

"I I am heartily glad to hear more instances of the success of the Poke weed in the cure of cancer. You will deserve highly of mankind for the communication. But I find in Boston they are at a loss to know the right plant, some asserting it is what they call Mechoacan, others other things. In one of their late papers it is publicly requested that a perfect decription may be given of the plant, its places of growth, \&c. I have mislaid the paper, or would send it to you. I thought you had described it pretty fully." Lelter from $\boldsymbol{B}$ r. Franklin to Dr. Colden.

"I apprehend that our poke-weed is what botanists term phytolacca. This plant bears berries as large as peas. The skin is black, but it contains a crimson juice. It is this juice thickened by evaporation in the sun which was employed. It caused great pain, but some persons were said to have been cured. I am not quite certain of the facts; all that I know is 
that Dr. Colden had a good opinion of the remedy." Letter from Dr. Franklin to M. Dubourg.

\section{Note $\mathbf{F}$.}

Linnæus, in his Flora Laponica, tells us that the roots of Calla palustris, although acrid and caustic in the highest degree, (ignis firme instar,) are made into a kind of bread in high estimation, called Missebroed. This is performed by drying and grinding the roots, afterwards boiling and macerating them until they are deprived of acrimony, when they are baked like other farinaceous substances into bread.

The recent juice of the Jatropha manihot, or Cassava tree of the West Indies, is highly poisonous. The deleterious principle however resides in a volatile portion, which is dissipated by heat. The remaining substance of the root is used by the inhabitants for bread, as a material for a kind of soup, and as the basis of a fermented liquor.

\section{Note G.}

The following is Kæmpfer's description taken from his Amœnitates Exoticæ, p. 791. His accompanying figure resembles the American Rhus vernix, except, that the end of the branch and bud are larger in proportion than with us.

"6 Sitz, vel. Sitzdsju, i. e. Sitz planta, vulgo Urus seu Urus no $k i$, Arbor vernicifera legitima, folio pinnato Juglandis, fructu racemoso ciceris facie.

"Arbor paucis ramis brachiata, salicis ad altitudinem luxuriose exsurgit. Cortice donatur incano, ex verruculis scabro, facile abscedente; ligno saligneo fragillimo; medulla copiosa, ligno adnata; Surculis longis crassis in extremitate inordinate foliosis. Folium est impariter pennatum, spithamale vel longius, Juglandis folio æmulum, costa tereti, leviter lanuginosa; quam a semipalmari nuditate stipant lobi sive folia simplicia, pediculo perbrevi nixa, tenuia, plana, ovata, trium vel quatuor unciarum longitu- 
dinis, basi inæqualiter rotunda, mucrone brevi angusto, margine integro, suprema facie obscure viridi, lævi, et ex nervis lacunosa, dorso incano et molliter lanuginoso. Nervus medius in mucronem terminans subinde multos a latere demittit nervos minores, citra marginem deficientes. Sapor folio sylvestris inest, cum sensibili calore; humor affrictus extemplo chartam ferrugineo colore imbuit. In surculis quibusdam ex foliorum axillis singuli surgunt Racemi laxe ramosi, palmares, tenues, qui, petiolis in calyculos rotundos desinentibus, Flosculos continent pumilos, et citra Coriandri seminis magnitudinem radiantes, in luteum herbaceos, pentapetalos, petalis carnosis nonnihil oblongis et repandis ; staminibus ad petalorum interstitia singulis, apicatis, brevissimis, stylo perbrevi tricipite, floris turbini insidente. Ordorem spirant dulcem, Aurantio flori affinem et pergratum. Fructus flosculum excipit gibbosus, utcumque in rhomboidis figuram compressus, bifidus, facie ac magnitudine ciceris, membranula tenui micante vestitus, per maturitatem durissimus et obsoleti coloris.

« Cortex arboris cultro crenatus lacteum fundit. lentorem, humore crystallino (ex aliis ductibus stillante) permixtum, qui ad aëris contactum nigrescit. Eundem surculi divulsi, foliorum pediculi, et nervi produnt, nullius gustabilis qualitatis participem, nisi califacientis sine acredine. Venenatos tamen spiritus hæ arbor exhalare dicitur, rehementes adeo, ut pueris circa eandem commorantibus exanthemata in corpore pariant : qualia etiam lignum tractantes alii (non omnes) experiuntur. Collectio Urusj, sive Vernicis, ut instituatur, caudices præcipue triennes, paucis crenis vulnerandæ sunt, ex quibus stillans liquor subinde excipitur, iterata in recente loco sectione, donec exsucci marcescant. Emulsi atque omni succo orbati, illico amputandi sunt; sic nova e radice provenit soboles, qua, triennis facta, collectioni denuo subjicitur." * * * * *

"Vernix nativa vix præparatione indiget. Japonica per duplicatam chartam subtilissimam, telæ aranearum pene similem, et 


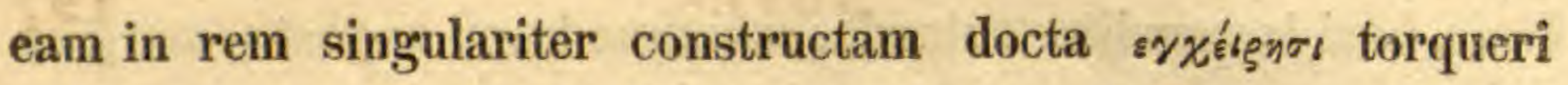
solet, ut a particulis heterogeneis et crassioribus mundetur; mundatæ pauxillum admiscetur (centissima fere pars) olei Toi dicti ex fructu arboris Kiri. Sic vasibus ligneis indita per Japoniam venalis transvehitur."

\section{Note $\mathrm{H}$.}

The following account of the death of Socrates is translated from the Phoedon of Plato.

And Crito hearing this gave the sign to the boy who stood near. And the boy departing after some time returned bringing with him the man, who was to administer the poison, who brought it ready bruised in a cup. And Socrates beholding the man, said, "Good friend, come hither, you are experienced in these affairs,-What is to be done ?" "Nothing," replied the man, "only when you have drank the poison, you are to walk about until a heaviness takes place in your legs. Then lie down. This is all you have to do." At the same time he presented him the cup. Socrates received it from him with great calmness, without fear or change of countenance, and regarding the man with his usual stern aspect, he asked, "What say you of this potion? Is it lawful to sprinkle any portion of it on the earth as a libation, or not ?" "We only bruise," said the man, "as much as is barely sufficient for the purpose." "I understand you," said Socrates, "but it is certainly lawful and proper to pray the gods that my departure from hence may be prosperous and happy, which I indeed beseech them to grant." So saying, he carried the cup to his mouth and drank it with great promptness and facility.

Thus far most of us had been able to refrain from weeping. But when we saw that he was drinking and actually had drunk the poison, we could no longer restrain our tears. And from me they broke forth with such violence, that I covered my face and deplored my wretchedness. I did not weep for his fate, so much, 
as for the loss of a friend and benefactor, which I was about to sustain. But Crito unable to restrain his tears was compelled to rise. And Apollodorus, who had been incessantly weeping, now broke forth into loud lamentations, which infected all who were present except Socrates. But, he observing us, exclaimed, "What is it you do, my excellent friends? I have sent away the women that they might not betray such weakness. I have heard that it is our duty to die cheerfully and with expressions of joy and praise. Be silent therefore, and let your fortitude be seen." At this address we blushed and suppressed our tears. But Socrates, after walking about, now told us that his legs were beginning to grow heavy, and immediately laid down, for so he had been ordered. At the same time the man who had given him the poison, examined his feet and legs, touching them at intervals. At length he pressed violently upon his foot, and asked if he felt it. To which Socrates replied, that he did not. The man then pressed his leg's and so on, shewing us that he was becoming cold and stiff. And Socrates feeling of himself assured us, that when the effects had ascended to his heart he should then be gone. And now the middle of his body growing cold, he threw aside his clothes and spoke for the last time, "Crito, we owe the sacrifice of a cock to Asculapius. Discharge this and neglect it not." "It shall be done, said Crito;

- have you any thing else to say ?" He made no reply, but a moment after moved, and his eyes became fixed. And Crito seeing this, closed his eyelids and mouth. 


\section{CONTENTS OF THE FIRST VOLUME.}

Datura stramonium,

Eupatorium perfoliatum,

Phytolacca decandra,

Arum triphyllum,

Coptis trifolia,

Arlnutus uva ursi,

Sanguinaria canadensis,

Geranium maculalum,

Triosteum perfoliatum,

Rhux vernix,

Conium maculatum,

Cicuta maculata,

Kalmia latifolia,

Spigelia marilandica,

Asarum canadense,

Iris versicolor,

Hyoscyamus niger,

Solanum dulcamara,

Lobelia inflata,

Solidago odora,

Notes,
Thorn apple, page 17

Thorough wort, 33

Poke, $\quad 39$

Dragon root, 52

Gold thread, $\quad 60$

Bearberry, $\quad 66$

Blood root, $\quad 75$

Cranesbill, $\quad 84$

Fever root, 90

Poison sumach, $\quad 96$

Hemlock, 113

American hemlock, $\quad 125$

Mountain laurel, $\quad 135$

Carolina pinkroot, $\quad 142$

Wild Ginger, $\quad 149$

Blue flag, $\quad 155$

Henbane, 161

Bitter sweet, $\quad 169$

Indian tobacco, $\quad 177$

Sweet scented Golden rod, 187 